\title{
DA RESPONSABILIDADE OBJETIVA DO COMODATÁRIO NO DIREITO ROMANO*
}

\author{
THE STRICT LIABILITY OF THE BORROWER IN ROMAN LAW
}

\section{Rodrigo de Lima Vaz Sampaio**}

\begin{abstract}
Resumo:
Enquanto sentido técnico, a custodia pode ser considerada sinônimo de responsabilidade objetiva. Os estudos de Direito Romano defendem ainda os critérios objetivo de responsabilidade do comodatário, no período clássico, e subjetivo, no período justinianeu. A partir da análise da História Interna do Direito Romano e da exegese das principais fontes antigas, pode-se chegar à conclusão que o comodatário, no período justinianeu e em algumas hipóteses, respondia por custodia.

Palavras-chaves: Commodatum. Critérios de responsabilidade civil: dolus, culpa, diligentia et custodia. História Interna do Direito Romano. Responsabilidade objetiva.
\end{abstract}

\begin{abstract}
:
In a technical sense, custodia can be considered synonymous of strict liability. Studies in Roman Law consider yet the strict liability of the borrower, in the classic period, and its subjective liability, in the period of Justinian. From the analysis of the Internal History of Roman Law, and of the exegesis of the main old sources, it can be arrived at the conclusion that the borrower, in the period of Justinian and in some hypotheses, was liable for custodia.
\end{abstract}

Keywords: Commodatum. Criteria of Civil Liability: dolus, culpa, diligentia et custodia. Internal History of Roman Law. Commodatum. Strict liability.

1. Introdução***

É praticamente impossível ler qualquer bom estudo sobre responsabilidade civil, em especial a respeito da responsabilidade objetiva, sem que seja ao menos citado

\footnotetext{
Este artigo constitui parte da Tese Láurea que obteve a nota máxima "10,0 (dez) cum laude" no Departamento de Direito Civil da Universidade de São Paulo. Um agradecimento especial deve ser feito ao Professor Titular Eduardo Cesar Silveira Vita Marchi, pela prestimosa orientação, e ao Professor Associado Dárcio Roberto Martins Rodrigues. Todos os preciosos conselhos por eles oferecidos foram de valor inestimável para a atual redação.

** Aluno do Curso de Pós-graduação da Faculdade de Direito da Universidade de São Paulo

*** Advertência quanto à metodologia empregada na tese: Todas as traduções são "livres" (pessoais). Utilizou-se dos colchetes ou parênteses quadrados - "[ ]" - para se referir a palavras ou expressões que não se encontram no original. Os colchetes foram ainda utilizados quando necessária a tradução de uma expressão ou de um texto específico no decorrer da tese.

Salvo os textos do Corpus Iuris Civilis, que foram todos obtidos na edição crítica de Paul Krueger e Theodor Mommsen, e das Gai Institutiones, extraídos de BAVIERA, Johannes. FIRA (Fontes Ivris Romani Anteiustiniani) II, as obras ou coletâneas das fontes antigas, onde estas foram colhidas, são mencionadas, quando for necessário, in loco.
} 
como exemplo o instituto jurídico do comodato - isso quando este não for o personagem central da pesquisa. Convido e desafio o leitor a fazer o teste, consultando seu próprio manual de estudos.

Tratar do comodato é se referir a um momento diacrônico, no qual o gesto de emprestar uma coisa para uso gratuito é transformado em um negócio juridicamente relevante e produtor de precisos efeitos jurídicos. ${ }^{1}$

Infelizmente, o estudo sistemático deste contrato somente encontraria um desenvolvimento aprofundado e sistemático nos idos de 1950, quando Franco

SANTARELLI, Umberto. Comodato nel diritto medievale e moderno. In: DIGESTO delle Discipline Privatistiche - Sezione Civile. Torino: UTET, 1998. v. 3, p. 34-35. Esta passagem de um plano nãojurídico para outro jurídico encontra-se na fala pretoriana de Ulp. 28 ad ed., D. 13, 6, 1 pr.: "Quod quis commodasse dicetur, de eo iudicium dabo" [= "Disse o pretor: 'Darei ação para aquele que diz que alguém deu em comodato"']. Por este motivo, Umberto Santarelli, embora foque sua análise no comodato da Idade Media, acredita que este quase sempre suscita, devido a sua própria colocação especial no âmbito jurídico, o equilíbrio entre cortesia e direito, o que constituiria o motivo suficiente para que despertasse os interesses de qualquer jurista. A causa desta transformação de um simples gesto fático de cortesia em um negócio jurídico relevante seria o caráter normativo conferido por um "costume imbuído de ética social", ou seja, que a força desta ética social determina, em um sistema obrigatório já constituído, o momento em que um simples ato de liberalidade assume a conotação de um negotium invicem gestum e o rigor de uma suscepta obligatio. Esta seria também a lição encontrada em Paul. 29 ad ed., D. 13, 6, 17, 3.

Para FORCHIELLI, Paolo. I contratti reali. Milano: Giuffrè, 1952. p. 2-5, em uma monografia sobre a realidade do comodato, do mútuo e do contrato estimatório, seria o próprio ato de entrega que, além de caracterizar o caráter real do contrato, seria capaz de o inserir dentro do universo jurídico. Logo, se por um lado, antes da entrega efetiva do bem, não seria possível existir comodato, por outro lado, esta carrega o estigma da relação não ser apenas fática, mas sim jurídica. 
Pastori, ${ }^{2}$ no Direito Romano, e Franco Carresi, ${ }^{3}$ no Direito Civil moderno, apresentaram, respectivamente, suas monografias à comunidade científica.

PASTORI, Franco. Il commodato in diritto romano (1954). 3. ed. Milano: Cisalpino, 1995. p. XV-476. Uma observação metodológica não pode deixar de ser feita quanto a esta obra de Franco Pastori. Apesar de sua primeira edição datar de 1954, sob o título "Il commodato nel diritto romano - Con contributi allo studio della responsabilità contrattuale", ela seria, primeiramente reeditada em 1982, com um novo título "Commodato - Contratto - Responsabilità", e, por fim, na atual versão de 1995. Mas, apesar das datas, títulos e edições variarem, o próprio PASTORI, Franco. Il commodato op. cit., p. XXI, assinala que não existem mudanças quanto ao conteúdo da obra, uma vez que ele não teria alterado seu posicionamento.

Além desta obra, a produção do autor sobre o tema é vasta: PASTORI, Franco. Comodato (diritto romano). In: AZARA, Antonio. Novissimo Digesto Italiano. Torino: UTET, 1959. v. 3, p. 688-692; PASTORI, Franco. Gaio e la responsabilità contrattuale. In: LABEO: Rassegna di Diritto Romano. Napole: Jovene, 1956. v. 2, p. 291-326; PASTORI, Franco. Sulla duplicità formulare dell'«actio commodati». In: LABEO: Rassegna di Diritto Romano. Napole: Jovene, 1956. v. 2, p. 89-94; PASTORI, Franco. Il contratto di comodato. Bologna: Cisalpino, 1997. p. 11-356 (esta última dedicada ao direito moderno).

Deve-se ficar claro que antes de Franco Pastori existiam obras de qualidade sobre o contrato de comodato no Direito Romano, e, inclusive sobre a responsabilidade do comodatário, mas estas se ora tratavam do tema apenas de forma marginal ou exemplificativa, não despertaram os interesses ou mesmos polêmicas como faria Franco Pastori. Cf., entre outras, ARANGIO-RUIZ, Vincenzo. Responsabilità contrattuale in diritto romano. 2. ed. Napoli: Jovene, 1987. p. 1-281; BARON, Julius. Pandekten. 9. ed. Leipzig: Duncker \& Humblot, 1896. p. 1-800 $(=\S \S 1-460)$; FERRINI, Contardo. Storia e teoria del contratto di commodato nel diritto romano. In: Opere di Contardo Ferrini: studi vari di diritto romano e moderno. Sulle obbligazioni, sul negozio giuridico, sulle presunzioni. Milano: Ulrico Hoepli, 1929. v. 3, p. 81-203; (_. Storia e teoria del contratto di comodato nel diritto romano. Archivio Giuridico "Filippo Serafini", Modena, v. 52, p. 469499, 1893 e v. 53, 1894, p. 41-73, 257-309, 1894]; DE RUGGIERO, Roberto. Depositum vel commodatum - Contributo alla teoria delle interpolazioni. Bullettino dell'Istituto di Diritto Romano, Roma, v. 19, p. 5-84, 1907; HASSE, Joham Christian. Die « Culpa » des römischen Rechts. 2. ed. Bonn: Adolph Marcus, 1838. p. III-579 (= §§ 1-99); LUZZATTO, Giuseppe Ignazio. Caso fortuito e forza maggiore come limite alla responsabilità contrattuale. La responsabilità per custodia. Milano: Giuffrè, 1938. v. 1, p. 1-63.

3 CARRESI, Franco. Il comodato - Il mutuo. In: VASSALLI, Filippo (Org.). Trattato di diritto civile italiano. Torino: UTET, 1950. v. 8, t. 2, p. 5-136. Também é para se atentar ao verbete Comodato (diritto civile) ( . Comodato. In: AZARA, Antonio (Org.). Novissimo Digesto Italiano. Torino: UTET, 1959. v. 3, p. $692-696$. Sobre o Direito Civil moderno, em italiano destacam-se também as obras de BORSARI, Luigi. Commentario del Codice Civile Italiano. Torino: UTET, 1881. v. 4, t. 2, p. $5-936$ (= $\$ 3.914-4.454)$; BRUNORI, Ernesto. Dei contratti specialli - Comodato. In: FINZE, Enrico; D'AMELIO, Mariano (Orgs.). Commentario al codice civile. Firenze: Barbèra, 1949. v. 2, p. 1-507; e FRAGALI, Michele. Del comodato. In: SCIALOJA, Antonio; BRANCA, Giuseppe (Orgs.). Commentario del codice civile - delle obligazioni. Bologna: Nicola Zanichelli, 1953. v. 4, t. 1, p. I-57. O próprio PASTORI, Franco. op. cit., p. 11-356, dedicou-se ao comodato no direito moderno, porém com menor profundidade que no Direito Romano.

Na literatura francesa, conferir as obras de BAUDRY-LACANTINERIE, Marie Paul Gabriel; WAHL, Albert. Traité théorique et pratique de droit civil. De la société, du prêt, du depôt. 2. ed. Paris: Des lois et des arrêts, 1900. p. 1-660 (= n. 1-1.318); POTHIER, Robert-Joseph. Traités du prêt a usage et du precaire. In:

Ouevres de Pothier. 3. ed. Paris: Marchal et Billard, 1890. v. 5, p. 1-38 (= n. 1-97); e TROPLONG, RaymondThéodore. Le droit civil expliqué - Du prêt. Paris: Charles Hingraus, 1845. t. 14, p. I-447 (= préface, n. 1-500). Quanto aos autores alemães, cf. KOBER, Karl; STAUDINGER, Julius Ritter. Leihe. Kommentar zum Bürgerlichen Gesetzbuch und dem Einführungsgesetz. Recht der Schuldverhältnisse. München: Schweitzer, 1929. v. 2, t. 2, p. 636-650 (= § 598-606).; e ENNECCERUS, Ludwig; KIPP, Theodor; LEHMANN, Heinrich; WOLFF, Martin. Lehrbuch des Bürgerlichen Rechts: Recht der Schulverhältnisse. Tübingen: Mohr, 1954. v. 2, p. 569-1.051.

Em português, a única obra existente é a de MARMITT, Arnaldo. Comodato. 3. ed. Rio de Janeiro: AIDE, 2002. p. 9-203, que trata apenas do direito moderno. 
Desta forma, pode-se com segurança considerar que foi graças à obra de Franco Pastori ${ }^{4}$ que, com os devidos limites, o tema da responsabilidade do comodatário voltou a ser o centro das atenções. O comodato já não gozava, como ainda hoje não, ${ }^{5}$ de interesse por parte da doutrina, caindo muitas vezes no anonimato. ${ }^{6}$

Este presente estudo visa, após esta breve introdução (item 1), em primeiro lugar, definir qual seria o sentido de "custodia" no Direito Romano (item 2), evitando-se, ao menos neste momento, a contaminação por um eventual maniqueísmo científico que se poderia ter devido ao marco tão forte em matéria de responsabilidade do comodatário de Franco Pastori ${ }^{7}$ - como ocorreu com alguns estudiosos que escreveram após este. ${ }^{8}$

Após esta rápida alusão, o estudo inicia-se propriamente com a análise da responsabilidade por custodia do comodatário (item 3), tendo-se em mente tanto o seu aspecto processual - a duplicidade formular -, bem como o argumento substancial - os diversos critérios de responsabilidade do comodatário nas fases da História Interna do Direito Romano.

Desta forma, chega-se à parte fundamental da exposição desta tese (item 4), concernente à exegese do texto de Gai. 2 aureor., D. 44, 7, 1, 4, e do significado do estranho critério de responsabilidade da "exactissima diligentia custodiendae rei".

Esforça-se, na medida do possível, por apresentar uma nova tese sobre a responsabilidade do comodatário, que objetiva contestar a tese tradicional segundo a qual o comodatário responderia apenas objetivamente no direito clássico e, a partir do direito justinianeu até os dias atuais, somente subjetivamente.

Por fim, expõem-se os resultados alcançados pela pesquisa (conclusão), pelos quais se visa comprovar no Direito Romano, e até mesmo no Direito Civil moderno, que a responsabilidade do comodatário nunca foi "simples" (baseada em um critério de

\footnotetext{
PASTORI, Franco. Il commodato. op. cit., p. XV.

Atualmente, DIAS, José Aguiar. Comodato. In: SANTOS, J. M. Carvalho. Repertório Enciclopédico do Direito Brasileiro. Rio de Janeiro: Borsoi, 1947. v. 10, p. 26, refere-se ao comodato como "contrato cada vez mais raro, na aplicação prática".

6 Cf. PASTORI, Franco. Il commodato. op. cit., p. XV-XVI. Este autor narra que quando começou a leitura das fontes não suspeitava da relevância que o instituto apresentaria, uma vez que este superava os limites de seu restrito regime jurídico e aplicação prática, passando a envolver as problemáticas gerais suscitadas pelo Direito Romano, em uma lógica reconstrutiva, quanto à responsabilidade contratual, ao processo e aos setores mais recônditos do negócio jurídico. Conta ainda que sua descoberta sobre o tema, dentro do horizonte romanístico, foi “casuale”, pois derivou dos seminários realizados pela Università de Napoli, que, logo após a $2^{\text {a }}$ Guerra Mundial, constituía um centro propulsor de novos estudos jurídicos na época. E o tema foi uma sugestão de Antonio Guarino, mestre que, com sua "verve”, dominava, na época, o local.

7 PASTORI, Franco. Il commodato. op. cit., p. XV-476. Esta obra utiliza como argumentos principais a duplicidade formular do comodato - actio in ius e actio in factum - e a responsabilidade do comodatário.

8 Uma monografia atual sobre o tema de TARDIVO, Carlo-Maria. Studi sul «commodatum». Archivio Giuridico "Filippo Serafini”, Modena, v. 204, p. 5-91, 1983. p. 44-45, refere-se à obra de Franco Pastori não somente como um marco, mas inclusive que existia um mundo "pré-" e "pós-" Franco Pastori.
} 
responsabilidade), mas sim "multifacetada" (baseada em diversos critérios), o que levaria a concluir, a contrario sensu, de que a responsabilidade por custodia do comodatário não foi extinta no direito justinianeu, apresentando-se, na prática, por um complexo sistema de presunções absolutas, ou até mesmo relativas.

\section{Apresentação do problema: a "custodia" no Direito Romano}

No domínio das obrigações contratuais, ao lado dos conceitos ou critérios jurídicos de responsabilidade do dolus, da culpa, da diligentia e do periculum, aparece o da custodia. ${ }^{9}$

O tema da custodia é um daqueles que a doutrina romana, a mais de um século, tem discutido e debatido cada vez com maior intensidade. ${ }^{10}$

A literatura, além de ser vastíssima, ${ }^{11}$ possui diversas orientações, mas é possível, desde mais ou menos vinte anos atrás, sob a sombra de numerosas pesquisas, principalmente, das obras de Vincenzo Arangio-Ruiz ${ }^{12}$ e de Giuseppe Ignazio Luzzatto, ${ }^{13}$ perceber que um determinado argumento tem prevalecido no tempo.

Assim, Giuseppe Ignazio Luzzatto ${ }^{14}$ demonstra a existência de dois sentidos básicos para a palavra "custodia". ${ }^{15}$

Pelo primeiro sentido, atécnico e justinianeu, indica uma atividade normal de custodiar, ${ }^{16}$ ou seja, a obrigação de guardar uma determinada coisa, assumindo a feição da responsabilidade subjetiva.

\footnotetext{
9 KUNKEL, Wolfgang. «Diligentia». Zeitschrift der Savigny-Stiftung für Rechtsgeschichte - Romanistische Abteilung, Weimar, v. 45, p. 266-351, 1925. p. 268.

10 METRO, Antonino. «Custodiam praestare». LABEO: Rassegna di Diritto Romano, Napole, v. 13, p. 60, 1955.

11 Cf., entre outros, ARANGIO-RUIZ, Vincenzo. Istituzioni di diritto romano. 14. ed. Napoli: Jovene, 2006. p. 1584; ARANGIO-RUIZ, Vincenzo. Responsabilità contrattuale in diritto romano. cit., p. 1-281; HAYMANN, Franz. Textkritische Studien zum römischen Obligationenrecht - I - Über Haftung für Custodia. Zeitschrift der Savigny-Stiftung für Rechtsgeschichte - Romanistische Abteilung, Weimar, v. 40, p. 167-350, 1919 (= §§ 1-7); KRÜCKMANN, Paul. Custodia. Zeitschrift der Savigny-Stiftung für Rechtsgeschichte - Romanistische Abteilung, Weimar, v. 64, p. 1-56, 1944. (= §§ 1-12); KUNKEL, Wolfgang. op. cit., p. 266-351. LUZZATTO, Giuseppe Ignazio. Caso fortuito... cit., p. 1-265; LUZZATTO, Giuseppe Ignazio. Custodia (diritto romano). In: AZARO, Antonio. Novissimo Digesto Italiano. Torino: UTET, 1960. v. 5, p. 93-94; MAYR, Robert. «Praestare». Zeitschrift der Savigny-Stiftung für Rechtsgeschichte - Romanistische Abteilung, Weimar, 1921. v. 42, p. 198-227; METRO, Antonino. op. cit., p. 60-67; PFLÜGER, Heinrich Hackfeld. Zur Lehre von der Haftung des Schuldners nach römischen Recht. Zeitschrift der Savigny-Stiftung für Rechtsgeschichte - Romanistische Abteilung, Weimar, v. 65, p. 121-218, 1947. (= §§ 1-8); e TALAMANCA, Mario. Custodia (diritto romano). In: ENCICLOPEDIA del Diritto. Milano: Giuffrè, 1958-. v. 11, p. 561-564.

12 ARANGIO-RUIZ, Vincenzo. Responsabilità... op. cit., p. 62-99.

13 LUZZATTO, Giuseppe Ignazio. Caso fortuito... op. cit., p. 1-63.

14 Id. Custodia ... op. cit., p. 93.

15 Devido a este caráter ambíguo, KUNKEL, Wolfgang. op. cit., p. 269, refere-se a um conceito múltiplo da custodia.

16 Segundo LUZZATTO, Giuseppe Ignazio. Custodia... op. cit., p. 93, este uso é encontrado até mesmo dentro
} 
Entretanto, no campo da responsabilidade contratual, a palavra assume uma fisionomia técnica, precisa, indicando o critério exato da responsabilidade objetiva.

Neste último sentido, custodia, enquanto critério de responsabilidade, e não mera obrigação de custodiar, assinala uma porção de risco imputada, dentro de certos limites, ao comodatário, independentemente do eventual aspecto subjetivo.

Assim, ela constituiria o critério segundo o qual aparece nas fontes romanas, inclusive nos Digesta, a responsabilidade por caso fortuito. ${ }^{17}$

O grande problema desta ambigüidade é saber quando e onde a palavra é usada em determinado sentido ou outro, ${ }^{18}$ tarefa esta que se tornaria mais complexa por obra dos compiladores, que, em diversos textos, desnaturam esta visão clássica da custodia, transformando-a em uma diligentia in custodiendo, que está sujeita às diversas incertezas decorrentes da valorização desta obra em matéria contratual. ${ }^{19}$

Segundo Hermann Gottlieb Heumann e Emil Seckel, ${ }^{20}$ o conceito de custodia era clássico e se ligava ao conceito de responsabilidade objetiva.

do âmbito da responsabilidade contratual, como, por exemplo, a guarda da coisa confiada, entre outros, ao familiae emptor, ao missus in possessionem. Para PASTORI, Franco. Il contratto... op. cit., p. 154, esta seria a acepção conferida pela linguagem comum à palavra custodia, a qual denota a atividade de proteção de um objeto contra os eventos exteriores.

17 Cf. KUNKEL, Wolfgang. op. cit., p. 266-351, 1925. p. 269. Para este, o conceito múltiplo da custodia representa a fronteira ou o limite do que pode ser conhecido sobre a teoria do caso fortuito. Este caráter múltiplo decorre especificadamente de um conjunto de casos fortuitos que não são incluídos dentro do âmbito da responsabilidade por custodia, e pelos quais o devedor não responderia. Estes acontecimentos se denominavam vis maior, como em Ulp. 28 ad ed., D. 13, 6, 5, 4, em Gai. 9 ad ed. provinc., D. 13, 6, 18 pr. e Ulp. 29 ad Sab., D. 50, 17, 23.

Segundo LUZZATTO, Giuseppe Ignazio. Custodia... op. cit., p. 93, existiria uma distinção no Corpus Iuris Civilis entre casus maior e minor com o propósito de justificar a responsabilidade do devedor por minores casus, que os compiladores teriam embutido no âmbito da custodia. Distinção esta que, a nosso ver, também pode ser encontrada em Gai. 2 aureor., D. 44, 7, 1, 4. Cf. exegese deste último texto no item 4, infra.

Mas contrariamente a Wolfgang Kunkel, Giuseppe Ignazio Luzzatto acredita que, por meio da idéia de que a jurisprudência clássica esforçou-se no sentido de enquadrar a responsabilidade do nauta no âmbito da custodia técnica, a criação de uma teoria do caso fortuito no período justinianeu somente se explicaria se entendesse o caso fortuito como um limite à responsabilidade subjetiva. Em outros termos, uma teoria do caso fortuito somente seria possível diante de um padrão de responsabilidade subjetiva, uma vez que caso fortuito é a ausência de culpa, e não pelo caso fortuito ser o evento que se insere dentro da responsabilidade por custodia. A própria distinção entre casus maior e minor só se explicaria se os compiladores desejavam não renunciar, mesmo no âmbito contratual, do emprego de uma presunção de culpa, com pequena vantagem sobre a custodia. Uma evolução que, para Giuseppe Ignazio Luzzatto, seria também demonstrada por textos que se encontram fora do Corpus Iuris Civiles, demonstrando a passagem de uma responsabilidade absoluta por furto a uma responsabilidade gradual subjetiva, como nos textos da Collatio Legum Mosaicarum et Romanarum.

18 TALAMANCA, Mario. op. cit., p. 562.

19 LUZZATTO, Giuseppe Ignazio. Custodia... op. cit., p. 93.

20 HEUMANN, Hermann Gottlieb; SECKEL, Emil. Handlexicon zu den Quellen des römischen Rechts (1846). 9. ed. Jena: Gustav Fischer, 1926. p. 116-117. 
Mario Talamanca ${ }^{21}$ acredita que, com certa tranquilidade, pode-se sustentar que a custodia, no direito clássico, corresponde a um critério objetivo de responsabilidade, isto é, aquele que impõe ao devedor a responsabilidade por determinados eventos, independentemente do comportamento deste, e, assim, entre a qualificação psíquica do comportamento frente ao evento. Tudo gira ao redor da possibilidade do devedor evitar o acontecimento.

As fronteiras desta responsabilidade seriam assim delimitadas dentro do próprio acontecimento concreto, pelo qual o devedor é chamado a responder. Gai. 3, 206207, por exemplo, inserem dentro da responsabilidade por custodia o furtum, quando trata da actio furti.22

Neste sentido, devido à dificuldade de se determinar qual seria o real conteúdo da custodia, Mario Talamanca ${ }^{23}$ impõe para a aplicação deste critério de responsabilidade, ainda no direito clássico, dois limites.

Em primeiro lugar, não seria concebível um "rapporto obbligatorio" [= "negócio jurídico obrigatório"], pelo qual se responderia apenas por custodia ${ }^{24} \mathrm{e}$, em segundo lugar, não se trata de um critério absoluto e geral de determinação da responsabilidade, mas sim um critério típico de determinadas hipótese, em que é obrigatória. ${ }^{25}$

21 TALAMANCA, Mario. op. cit., p. 562.

22 A esta altura, vale a observação de que TALAMANCA, Mario. op. cit., p. 562, acredita que somente ao final do período clássico, e talvez por um choque do critério subjetivo, tenta-se ampliar o âmbito de cabimento da custodia. Conforme, LUZZATTO, Giuseppe Ignazio. Custodia... op. cit., p. 93-94, Gai 9 ad ed. provinc., D. 13, 6, 18 pr., e Ulp. 29 ad Sab., D. 50, 17, 23, vislumbram a possibilidade de incluir no âmbito da custodia a "fuga servorum qui custodiri solent”. Cf. também Ulp 14 ad ed., D. 4, 9, 1 pr., e Gai. 5 ad ed. provinc., D. 4, 9, 5 pr. Para PASTORI, Franco. Il contratto... op. cit., p. 154-155, em Gai. 3, 202-207, existe uma diversificação do regime de responsabilidade do devedor. $\mathrm{O}$ credor pignoratício deve custodiar a coisa transferida a ele em garantia, como também certos artesãos, como o fullo [= "tintureiro"] e o sarcinator [= "alfaiate"], que detêm a vestimenta $[=$ roupas $]$ a elas confiadas pelos clientes. Também neste rol de devedores se inclui o comodatário e o depositário.

Entretanto, se primeiramente custodia pode denotar uma obrigação genérica de custodiar, nas fontes romanas, a palavra assumiu um sentido bem distinto do inicial, ou seja, de responsabilidade que deriva para o devedor do inadimplemento de sua obrigação de defesa e proteção da coisa a ele confiada. Responsabilidade esta de natureza objetiva, a qual se refere à regra e à diç̧ão "custodiam praestare", da qual fala Gai. 3, 205-206, para o fullo, o sarcinator e o comodatário, em oposição a Gai. 3, 207, que trata da responsabilidade do depositário. Assim, pode-se dizer que as fontes diversificam a responsabilidade do comodatário e do depositário, ambos vinculados à obrigação de custodiar a coisa, mas sendo que o primeiro "custodiam praestat", e o segundo "custodiam non praestat", respondendo somente por dolo.

23 TALAMANCA, Mario. op. cit., p. 562-563.

24 Por este primeiro limite, TALAMANCA, Mario. op. cit., p. 562-563, acredita que a custodia refere-se diretamente à obrigação de restituir, que não deve ser confundida com a obrigação de fazer, uma vez que esta é gênero, enquanto a primeira é espécie, podendo existir outras hipóteses de não-restituição que estejam fora do furtum. Em outras palavras, nos negócios em que a obrigação de fazer corresponde praticamente àquela de restituir - como na locação e no comodato - existem hipóteses onde a coisa não é restituída e não se aplica o estrito critério da custodia.

25 Neste segundo limite, a custodia seria exclusivamente tutelada ou pelos iudicia bonae fidei ou pelas formulae in factum concepta. Este critério de responsabilidade é utilizado quando o devedor obtém a disponibilidade 
Custodia significa, assim, no direito clássico, “Bewachung, Beschützung, Beaufsichtigung, [und] Berwahrung" [= "guarda, proteção, controle e preservação"]. ${ }^{26}$

No decorrer do período pós-clássico, o instituto atravessa por uma evolução que conduz até o direito justinianeu, onde a palavra apresentaria uma variação de conteúdo e de sentido. ${ }^{27}$

A evolução teria sido total para Giuseppe Ignazio Luzzatto, ${ }^{28}$ no sentido desta deixar de ser um critério de responsabilidade (objetiva), e passar a ter um sentido atécnico, ou seja, uma mera obrigação de guarda inserida dentro do âmbito da responsabilidade subjetiva, e sem qualquer traço do seu caráter original.

No entendimento de Mario Talamanca, ${ }^{29}$ embora a custodia de critério objetivo passasse a ser tratada como critério subjetivo de responsabilidade, sob a rubrica da diligentia exacta (exactissima) custodiendae rei, ${ }^{30}$ esta "riproduce sino a un certo punto il contenuto della 'custodia' classica, in base ad un sistema di presunzioni di colpa" [= "reproduz dentro dos devidos limites o conteúdo da custodia clássica, com base em um sistema de presunções de culpa"].

Em outras palavras, a custodia teria sido mantida através da estranha figura da diligentia exacta (exactissima) custodiendae rei.

Julius Baron, ${ }^{31}$ partindo da diferença em que o devedor pode, no Direito Romano responder por sua própria culpa - "für eigene Schuld" - ou mesmo além dessa - "über die eigene Schuld hinaus" - foi quem cunhou os conceitos de "objective Custodia" [= "custódia objetiva ou atécnica"] e "subjective Custodia" [= "custódia subjetiva ou técnica"]. ${ }^{32}$

Assim, trata-se de caso de custodia objetiva, ou atécnica, quando o sujeito responde apenas e tão somente pela própria culpa. ${ }^{33}$

da coisa - e, por isso, o poder de controle sobre esta - para seu exclusivo interesse ou em função do adimplemento da obrigação consistente em um facere, como no comodato e na locação. Sobre qual fórmula tutela a custodia, cf. item 3. 1, infra.

26 HEUMANN, Hermann Gottlieb; SECKEL, Emil. op. cit., p. 116-117.

27 Id. Ibid.; e M. TALAMANCA, Mario. Custodia. cit. (nota 17 supra), p. 563.

28 LUZZATTO, Giuseppe Ignazio. Custodia. cit., p. 93-94.

29 TALAMANCA, Mario. op. cit., p. 563.

30 Cf. exegese de Gai. 2 aureor., D. 44, 7, 1, 4, no item 4, infra. A custodia tonar-se-ia, para TALAMANCA, Mario. op. cit., p. 562-563, com a tradição justinianéia, nada mais do que uma hipótese particular de diligentia denominada "custodiendae rei" ou "exacta (exactissima) diligentia". Embora reorganizada sobre a égide da responsabilidade subjetiva, aos pós-clássicos poderia ser atribuído um não-controverso traço de responsabilidade objetiva, existente até mesmo nas fontes justinianéias.

31 BARON, Julius. op. cit., p. 427, 429-430 (= § 237).

32 Id. Ibid., p. 429-430 (= § 237). Deste posicionamento decorreu que o conceito de custodia não é uno, mas, pelo contrário, é duplo: seria um conceito de responsabilidade bipolar. Observa-se que Julius Baron parece inverter os denominadores da responsabilidade, isto é, a custodia objetiva é a atécnica (subjetiva) e a subjetiva a técnica (objetiva). Trata-se de uma confusão comum ocorrida nos escritos do século XIX, que ainda não determinavam com precisão os critérios de responsabilidade.

33 Id. Ibid., p. 429 (= § 237). Seria, por exemplo, quem entrega uma coisa a outrem, tendo por fundamento 
Por outro lado, a custodia subjetiva, ou técnica, impõe ao devedor que este deva, sem qualquer alternativa, devolver pessoalmente coisa alheia, e, além disso, deverá arcar com danos e perdas ocasionados por culpa de terceiros e até por caso fortuito, especialmente no caso de furto e deterioração da coisa por fato de terceiro.

O devedor que responde por custodia subjetiva apenas vê suas obrigações afastadas no caso de vis maior [= "força maior"], como no caso do roubo, que não haveria como ser impedido. ${ }^{34}$

O motivo e justificação inerente da responsabilidade pela custodia subjetiva é a "Verkehrsbedürftnis" [= "necessidade da relação"], ${ }^{35}$ pela qual quanto maior o porte de uma relação, maior é o interesse isolado do devedor nesta.

O caso típico de responsabilidade por custodia subjetiva, pela qual o devedor responde pelo fato alheio, e por qualquer caso de dano, exceto os provenientes de força maior, é na hipótese do devedor receber uma coisa de terceiro: o caso do comodatário.

Assim, para Julius Baron, ${ }^{36}$ o comodatário continuaria a responder por custodia subjetiva no direito justinianeu.

Desta forma, no mínimo três tendências se instauram quanto à custodia no direito justinianeu: esta teria sido extinta, sendo apenas utilizada no sentido atécnico, ${ }^{37}$

um negócio bonae fidei, como é o caso do vendedor. Responde igualmente por custodia objetiva quem está tomando conta de um negócio ou de um coisa para terceiro, como é o caso do mandatário ou do depositário. 34 Id. Ibid., p. 429-430 (= § 237).

35 Segundo PASTORI, Franco. Comodato. op. cit., p. 690, a responsabilidade por custodia deriva obviamente da cristalização da atividade de vigilância daquele que a exerce, com respeito aos casos típicos em que a coisa poderia se perder, justamente o furto, a amissio rei, e a fuga do animal.

36 BARON, Julius. op. cit., p. 427, 429-430 (=§ 237).

37 LUZZATTO, Giuseppe Ignazio. Custodia. cit., p. 93-94. 
alguns traços da custodia clássica se mantiveram no direito justinianeu, ${ }^{38}$ ou a custodia se manteve integralmente no direito justinianeu. ${ }^{39}$

Franco Pastori ${ }^{40}$ acredita que este dúplice sentido da custodia foi cortado por Justiniano, que teria omitido a palavra no sentido de responsabilidade objetiva, por motivos de uma política legislativa, que afasta a responsabilidade objetiva por clemência do devedor, introduzindo a responsabilidade contratual no contexto da responsabilidade culposa.

38 TALAMANCA, Mario. op. cit., p. 562-563. Estes detectáveis vestígios da responsabilidade por custodia do comodatário podem ser encontrados em pelo menos três grupos diferentes de textos. No primeiro, a palavra "custodia" aparece nas fontes, sem quaisquer transformações realizadas pelos juristas pós-clássicos ou compiladores justinianeus. É o caso, por exemplo, de Ulp. 28 ad ed., D. 13, 6, 5, 6 e 14 . O problema destes textos é saber em qual deles a palavra foi mantida em sentido técnico originário e em quais foi usada no atécnico. No segundo grupo de textos, a custodia vem transfigurada em um critério diverso de responsabilidade, embora na prática, não fique tal critério longe das características originais. É o caso do diligentissimus pater familias de Gai. 9 ad ed. provinc., D. 13, 6, 18 pr., da exacta diligentia custodiendae rei" de Inst. 3, 14, 2, ou da exactissima diligentia custodiendae rei de Gai. 2 aureor., D. 44, 7, 1, 4 (cf. a exegese destes textos no item 4, infra). Por fim, em um outro grupo de textos ou estes não se referem ao critério de responsabilidade do comodatário, ficando esta subentendida, ou passaram por uma alteração marginal pós-clássica ou justinianéia. Os mais interessantes são Ulp. 28 ad ed., D. 13, 6, 5, 3 e 4, aquele se referindo ao comodato de coisa avaliada e este ao "princípio do sacrifício da coisa própria".

Entretanto, deve-se observar que, até os dias de hoje, a fonte que talvez se pode considerar a mais completa sobre o "princípio do sacrifício da coisa própria" não é o texto de Ulpiano, o de PS. 2, 4, 2, ou as legislações modernas (previsão expressa nos arts. 583 do CC/2002; 1.253 do CC/1916; 1.882 CC Francês; 1.810 do CC Italiano de 1865 revog.; $1.805, \S 1^{\circ} \mathrm{CC}$ Italiano; art. 1.516, Parágrafo Único CC Português de 1867 revog.; e, implicitamente, no $\S 603$ BGB), mas sim o da L. Vis. V, 5, 5, embora com as particularidades da fattispecie marítima: "(De Rebus conmendatis et casu quocumque in naufragium missis) Qui conmendata susceperit vel commodata et de ruina aut incendio vel hostilitatis naufragio seu quolibet simili casu sua omnia liberaverit et alinea perdiderit, quod accepit sine aliqua excusatione cogatur exsolvere. Si vero partem aliquam de rebus propriis liberasse cognoscitur, illi, cuius res secum habuerat, iuxta modum perdite rei vel liberate restituat, qualem iudex rationem deducta estimaverit portionem. Sin autem sua omnia perdiderit, cum liberaret aliena, et de liberatis et de perditis rebus similis ratio deducatur, ut partem arbitrio iudicantis qui liberabit accipiat. Iustum est enim simili casu, ut ille non damnum solus excipiat, qui ae gravibus obiecerit periculis, et dum aliena minora conatur liberare, sua maiora cognoscitur perdedisse". [= "(Sobre o empréstimo de coisas a outrem e a perda por acidente marítimo). Se alguém confia a outrem uma coisa pessoal, e este a perde, por ruína, incêndio, naufrágio ou qualquer outro evento similar, mas, no mesmo momento, salva suas próprias coisas da destruição, deve este ser compelido a dar total satisfação pelo o que lhe foi confiado e não poderá ser dada a oportunidade de oferecer qualquer defesa. Mas, se ele tiver conhecimento que salvou qualquer das suas próprias coisas deve devolver ao comodante um montante na proporção das coisas perdidas e salvas, o qual o juiz deve decidir conforme a equidade. Se ele tiver perdido todas as suas coisas, e salvou apenas as coisas que lhe foram emprestadas, aplica-se a mesma regra: e o comodatário deve receber uma parte daquilo que foi salvo quando o juiz, após ouvir ambas as partes, irá decidir. Nestes casos não é justo que o comodatário sozinho seja exposto a grande perigo para evitar a perda, pois, enquanto ele estiver tentando salvar as coisas emprestadas de menor valor, perderá todas as suas coisas"]. Trata-se da fonte que começa a delinear, no seu final, a hipótese das coisas emprestada e pessoal do comodatário terem valores diversos, a qual seria retomada, no século XIX, por POTHIER, Robert-Joseph. op. cit., p. 23-24 (n. 56). Texto em latim de ZEUMER, Karl. Monumenta Germaniae Historica - Legum Sectio - Leges Visigothorum, v. 1, 1902.

39 BARON, Julius. op. cit., p. 427, 429-430 (= § 237).

40 PASTORI, Franco. Il contratto... op. cit., p. 155. 
O comodatário responderia, no direito justinianeu, por uma exactissima diligentia custodiendae rei, expressão que requer do comodatário uma elevadíssima diligência no adimplemento de sua obrigação de custodiar a coisa emprestada. ${ }^{41}$

Mas esta mudança terminológica, soa para o próprio Franco Pastori, ${ }^{42}$ como uma mera "prospettiva formale" [= "perspectiva formal"], pois não deixaria de ser, na prática, uma responsabilidade agravada a do comodatário.

Este duplo sentido da palavra custodia viria a ser perdida após o período justinianeu, ${ }^{43}$ permanecendo apenas no sentido atécnico de obrigação de custodiar, ${ }^{44}$ e sendo seu sentido técnico substituído pela expressão "responsabilidade objetiva", uma vez que a responsabilidade além do dolo e da culpa somente pode ser "objetiva". ${ }^{45}$

41 FRAGALI, Michele. Del comodato. In: SCIALOJA, Antonio; BRANCA, Giusuppe (Orgs.). Commentario del codice civile. Delle obligazioni. Bologna: Nicola Zanichelli, 1953. v. 4, t. 1, p.1-571. p. 279.

42 PASTORI, Franco. Il contratto... op. cit., p. 155.

43 TALAMANCA, Mario. op. cit., p. 562-563.

44 CARRESI, Franco. Il comodato... cit., p. 59-61, alude que é neste sentido que o art. 1.804 , § $1^{\circ}$ do CC Italiano, usa "custodia" na frase "il comodatario è tenuto a custodire e conservare la cosa con la diligenza del buon padre di famiglia. [...]”, repetindo o art. 1.808 do CC Italiano de 1865 revog., que dizia "il comodatario è tenuto a vegliare da buon padre di famiglia alla custodia e conservazione della cosa prestata, [...]”.

Não se pode deixar de notar que a redação do art. $1.804, \S 1^{\circ}$ do CC Italiano, relembra o texto do art. 1.880 do CC Francês "L'emprunteur est tenu du veiller, en bon père de famille, à la garde et à la conservation de chose prêtée. [...]" (a expressão francesa "veiller à la garde" aludiria aqui à custodia em sentido atécnico, uma vez que o comodatário "é tenuto a custodire e conservare" ou "est tenu du veiller à la garde et à la conservation”). No mesmo sentido, o art. 1.514 do CC Português de 1867 revog.: "O comodatário tem obrigação de velar pela conservação da cousa emprestada, como se fôra sua própria”, que repete, em síntese, o início de Ord. Filip. 4, 53, 2 revog.: "E porque este contracto se faz regularmente em proveito do que recebe a cousa emprestada, e não do que a empresta, fica obrigado aquelle, a que se empresta, guardal-a com toda a diligencia, como se fôra sua. E não somente se lhe imputará o dolo e culpa grande, mas ainda qualquer culpa leve e levissima, assi pola cousa principal, como polo accessorio. E por tanto, se hum emprestasse huma egoa a outro, a qual comsigo levasse hum poldro, a mesma obrigação terá na guarda do poldro, que na da egoa". Por fim, o art. 1.251 do CC/1916 revog., retomando, as Ordenações Filipinas diz que "o comodatário é obrigado a conservar, como se sua própria fora, a coisa emprestada”, atual texto do art. 582 do CC/2002 (o § 603 do BGB apenas faz uma alusão indireta à obrigação de custodiar, quando impõe ao comodatário a obrigação de se ater ao uso contratualmente cedido a ele: "Der Entleiher darf von der geliehenen Sache keinen anderen als den vertragsmäßigen Gebrauch machen”). Enfim, em todos estes textos se refere, explicitamente ou não, à obrigação de custodiar do comodatário, isto é, à custodia em sentido atécnico.

45 PASTORI, Franco. op. cit., p. 328. 
3. Os fundamentos da responsabilidade por "custodia” do comodatário 46

\section{1. A duplicidade formular - "actio in factum" $e$ "actio in ius" - aplicada ao regime jurídico do comodato}

A disciplina sobre o comodato, que chegou até os dias atuais, encontrase, salvo algumas exceções, compilado, principalmente, sobre o título "Commodati [vel contra]" dos Digesta (D. 13, 6). ${ }^{47}$

Por meio da expressão "propositae sunt actiones", Paul. 29 ad ed., D. 13, 6, 17, 3, marca o momento em que o empréstimo de uso passa a ser juridicamente tutelado. ${ }^{48}$

46 Para que seja imputada ao comodatário uma responsabilidade por custodia, dois aspectos, basicamente, devem concorrer e serem adequadamente preenchidos, em qualquer período da História Interna do Direito Romano: o processual (item 3. 1, infra), para que a custodia possa ser exigida, e o substancial (item 3. 2, por inteiro, infra), pelo qual efetivamente, dentro da fattispecie analisada, o comodatário responderia objetivamente.

47 LENEL, Otto. Das Edictum Perpetuum: Ein Versucht zu seiner Wiederherstellung (1883). 3. ed. Leipzig: Tauchnitz, 1927. p. 252-254 (= § 98), observa, logo no início de sua exposição sobre as fórmulas no comodato, que a rubrica "Commodati vel contra" é própria dos Digesta (D. 13, 6), uma vez que na rubrica do Codex (C. 4, 23) apenas está escrito "De Commodato”, faltando a terminação "vel contra”. Este detalhe demonstraria que a expressão "vel contra" não é propriamente original, mas antes foi escolhida e composta pelos compiladores, já que muito provavelmente o mesmo ocorreu em outras rubricas como "De pigneraticia actione vel contra" (D. 13, 7), "Depositi vel contra" (D. 16, 3) e "Mandati vel contra” (D. 17, 3), ou seja, curiosamente os três típicos contratos reais do Direito Romano - o comodato, depósito e penhor - e um consensual - o mandato. Assim, "vel contra" é obra dos compiladores (assim, a expressão "vel contra", por orientação de Otto Lenel, será reproduzida entre colchetes ou parênteses quadrados).

Dentro deste título "Commodati [vel contra]" destacam-se, como os principais juristas romanos que escreveram sobre o assunto, Ulpiano em seu livro 28 ad edictum, principalmente no conjunto de textos de D. 13, 6, 5; Paulo no seu livro 29 ad edictum, com maior destaque para D. 13, 6, 17, 3; Gaio no livro 9 ad edictum provinciale, em D. 13, 6, 18, e também deve se sinalizar a presença de Juliano, que, excetuados outros casos, em D. 13, 6, 5, 8, é tomado como base por Ulpiano.

Os principais textos das fontes jurídicas romanas, fora do título "Commodati [vel contra]" (D. 13, 6), são: o título "De commodato" (C. 4, 23) do Codex, que contém 4 escritos dos imperadores Dioclesiano e Maximiano; as Inst. 3, 14, 2, e 4, 1, 16; os textos do título "De commodato et deposito pignore fiduciave” (PS. 2, 4, 1-4) das Sententiae Receptae Paulo Tributae; os textos da Modest., Coll. 10, 2, 1, 4-6 (embora sobre a rubrica "De deposito", trata-se de um conjunto de textos sobre o comodato); o C. Th. 2, 31, 1; e Gai. 3, 202207 e Gai 4, 47 e 62.

48 PASTORI, Franco. Il commodato... cit., p. XVI-XVII. A origem jurídica do comodato, isto é, sua passagem de um mero ato social para um negócio juridicamente relevante, tem suscitado igualmente relevantes considerações dogmáticas.

O texto de Paul. 29 ad ed., 13, 6, 17, 3, para Franco Pastori, demonstra nitidamente que seria por meio da palavra "beneficium" que o direito passou a reger juridicamente o empréstimo de uso, bem como a classificação negocial seria obtida pela operatividade das ações e das obrigações, que passaram a vincular ambas as partes.

Embora não sejam obrigações recíprocas, como narra o texto, devido a sua bilateralidade imperfeita - alguns, atualmente, como CARRESI, Franco. Il comodato ... cit., p. 19-21, falam em unilateralidade -, a natureza de vínculo jurídico é claríssima ao jurista que a relaciona à confiança depositada na outra parte pelo voluntário exercício da autonomia privada de quem entrega o beneficium e que passa a respeitar a própria e livre determinação, suportando eventuais prejuízos com base no princípio da auto-regulação privada.

Estando na expressão "beneficium tribuit" [= "entregar o benefício"] a prova cabal da natureza jurídica do comodato, pode-se dizer que o vínculo jurídico nasce de um comportamento por parte do comodante 
Ao utilizar o verbo "proponere", Paulo se refere diretamente a uma tutela pretoriana e às ações concedidas pelo magistrado, principalmente, quando se leva em consideração que o texto encontra-se no título D. 13, 6 ("Commodati vel contra"), o qual, por sua vez, estrutura-se sobre estratos jurisprudenciais de comentários do edito reservado ao comodato, assim, o livro $28^{\circ}$ de Ulpiano e o livro $29^{\circ}$ de Paulo, respectivamente, de seus comentários ao edito do pretor urbano, e o livro $9^{\circ}$ de Gaio de seus comentários ao edito provincial. ${ }^{49}$

A ação proposta por Paulo consistia em uma actio in factum concedida pelo pretor ao comodante, a qual se acrescentaria, dois séculos mais tarde, talvez no fim do século I d. C., uma ação civil - in ius -, como demonstra Gai. 4, 47..$^{50}$

Assim, de forma semelhante, Vincenzo Arangio-Ruiz ${ }^{51}$ trata do fenômeno da duplicidade formular no comodato, partindo não do texto de Paulo, mas sim da narração existente em Ulp. 28 ad ed., D. 13, 6, 1 pr., o qual, por sua vez, afirma que primeiramente o comodato foi tutelado por uma actio in factum, ou por uma "apropriada cláusula edital".

A actio in ius seria concedida em um processo análogo ao que ocorreu com o contrato de depósito, sendo que este somente se completou muito tardiamente, talvez pela primeira vez no Edito de Juliano. ${ }^{52}$

autovinculante, uma vez que a expressão revela nitidamente o comportamento de quem dá, confere o benefício, ou seja, do credor.

Assim, na passagem do mundo social para a realidade jurídica somente importa a entrega da coisa feita pelo comodante, ou seja, o foco é neste, e não no comodatário, como o é na expressão "custodiam praestare" disseminada por diversos fragmentos das fontes romanas. Cf. sobre a presença da expressão "custodiam praestare" nas fontes romanas, desde Gai. 3. 206, no item 3. 2. (Culpa e custódia enquanto parâmetros de responsabilidade do comodatário).

Por fim, a questão relativa ao reconhecimento jurídico do comodato liga-se à sua história, enquanto que, em oposição a outros negócios jurídicos de maior destaque, este apenas obteve tutela processual em época relativamente tardia, não antes do século I. a. C., e depois de ter ampla aplicação na prática. É a demanda social que exigiu a tutela e o reconhecimento jurídicos, sendo considerado o instituto um ponto de convergência das normas sociais com o ordenamento jurídico. Assim, Paul. 29 ad ed., 13, 6, 17, 3, é um fragmento vital tanto para a identificação do reconhecimento jurídico do comodato, como da duplicidade formular neste contrato.

49 PASTORI, Franco. op. cit., p. XVI. Além desses, que são os principais a tratarem da duplicidade formular, também não devem ser esquecidos o livro $5^{\circ}$ de Pompônio de seu comentário à obra de Sabino, o livro $5^{\circ}$ de Marcelo e o livro $1^{\circ}$ de Juliano de seus textos classificados e organizados, e, por fim, o livro $8^{\circ}$ de Africano de questões propostas ao jurisconsulto.

50 PASTORI, Franco. Il commodato... cit., p. XVI. Sobre as várias possibilidades de se classificar as actiones no processo formulário, cf. ALVES, José Carlos Moreira. Direito Romano. História do Direito Romano. Instituições de Direito Romano; parte geral. Parte Especial: direito das coisas. 13. ed. Rio de Janeiro: Forense, 2004. v. 1, p. 229-233 (=n. 131).

51 ARANGIO-RUIZ, Vincenzo. Istituzioni... op. cit., p. 314.

52 A existência de uma actio in factum e de uma "actio in ius toma como referência dois critérios, a saber, quanto à origem da norma jurídica e sua intentio - as ações podem ser civis (in ius) ou pretorianas (honorariae); entre estas últimas, encontram-se as actiones ficticiae, as actiones com transposição de sujeito e as actiones in factum - e quanto aos poderes atribuídos ao iudex para decidir o litígio - actiones stricti iuris, ações arbitrárias e ações de boa-fé (iudicia bonae fidei). Cf. detalhes em ALVES, José Carlos Moreira. Direito Romano. op. cit., p. 229-233 (= n. 131). 
Mas não se pode deixar de se considerar que os pressupostos das duas ações encontram fundamentos e raciocínios diferentes. ${ }^{53}$

Enquanto a actio in factum concepta pressupõe a falta de restituição da coisa por parte do comodatário - "non reddere" - para que ocorra a condenação deste, obrigando-o a corresponder apenas pelo valor de mercado - "quanti ea res est" [= "quanto objetivamente vale a coisa", ou seja, o dano emergente] -, a actio in ius concepta não vincula sua propositura à devolução da coisa, comportando, além disso, um juízo ex fide bona, cujo pressuposto é o modelo de comportamento da pessoa correta. ${ }^{54}$

Assim, no juízo de boa-fé o pressuposto da ação adequou-se à decisão jurisprudencial, transformando a condenação em uma quantia praticamente indeterminada - "quidquid ob eam rem dare facere oportet ex fide bona" [= "é preciso que com boa-fé se faça tudo pela coisa"]. ${ }^{55}$

Quanto às ações baseadas na boa-fé, é útil considerar que estas eram de número limitado, conforme Gai. 4, 62,: "ex empto vendito, locato conducto, negotiorum gestorum, mandati, depositi, fiduciae, pro socio, tutelae, rei uxoriae".

53 PASTORI, Franco. Il commodato... op. cit., p. XVII.

54 Segundo SOLAZZI, Siro. Recensão a PASTORI, Franco, Il commodato nel diritto romano - Con contributi allo studio della responsabilità contrattuale. Milano: Giuffrè, 1954. IVRA: Rivista Internazionale di Diritto Romano e Antico, Napoli, v. 6, p. 258-270, 1955, Franco Pastori trata da actio commodati, utilizando de Gai. 4, 47 e 62, para combater a tese de SEGRÉ, Gino. Sull'età dei giudizii di buona fede di comodato e di pegno. In: STUDI giuridici in onore de Carlo Fadda. Napoli: Luigi Pierro, 1906. v. 6, p. 333-390, segundo o qual a formula in ius não mencionava a bona fides.

A crítica de Siro Solazzi é veemente: o repúdio a esta tese de Gino Segré vem em boa hora, mas a análise dos fragmentos das Gai Institutiones, realizada por Franco Pastori, não trazem nenhum avanço ao tema. Em Gai 4, 47, Franco Pastori detém-se sobre a palavra "similes", dizendo que a fórmula da actio commmodati não pode ser idêntica à da actio depositi, mas também não muito diversa, já que Gaio fala em semelhança. Mas, para Siro Solazzi, se Franco Pastori tivesse pensado como um estudante da época de Gaio teria entendido o termo "similes", concluindo pela ausência de qualquer traço definitivo sobre a coincidência ou a diferença de ambas as fórmulas, pois o texto não as enuncia. Em seguida, analisaria Gai. 4, 112, que no manuscrito veronense, coloca um "similis" obscuro em "excepta iniuriarum actione et si qua alia similis inveniatur actio" e teria com sagacidade excluído "et ... actio".

Em Gai. 4, 47, é duvidoso se "similes etiam commodati formulae sunt" não seja de Gaio, sendo fruto de alguma interpolação ou glossema, pois o jurisconsulto somente construía exemplos com o depósito, ao qual não pertenceria nem mesmo as palavras "veluti depositi et commodati". A questão se o "veluti" seja taxativo ou não é uma questão de menor relevo, pois ao jurista clássico, que escreve para estudantes, é permitido usar uma linguagem equivocada. Assim, por exemplo, Gai. 4, 59, apresenta, provavelmente um glossema em "velut commodati et depositi", e Gai. 4, 60, fala apenas do depósito. Na obra de Gaio, também Gai. 4, 33, cita "actio commodati", e este fragmento - especialmente na frase "eiusdem naturae sunt actiones commodati, fiduciae, negotiorum gestorum et aliae innumerabiles" - conjuntamente com Gai. 4, 33, ao contrário do que sustenta Franco Pastori, podem ser questionados em sua autenticidade.

De qualquer forma, como demonstra FRANÇA, Rubens Limongi. Contrato de empréstimo. In: Enciclopédia Saraiva do Direito. São Paulo: Saraiva, 1977. v. 19, p. 320-324, e PERRIS, Corrado. Comodato (contratto di). In: D’AMELIO, Mariano. Nuovo Digesto Italiano. Torino: UTET, 1938. v. 16, p. 403-408, a obrigação de restituição é a mais importante do comodatário.

55 PASTORI, Franco. Il commodato... op. cit., p. XVII-XVIII. 
Em outras palavras, na condenação haveria uma diferença sutil e substancial, pois, enquanto na ação pretoriana a interpretação seria estrita e a condenação no valor de mercado do bem, na ação civil existiria uma ponderação do valor por força do juízo de boa-fé, o que possibilitaria não somente a indenização por dano emergente, mas inclusive por lucros cessantes. ${ }^{56}$

Ademais, sendo a primazia da fórmula in factum sobre a in ius tratada como mera decisão histórica da qual não se poderia fugir, uma vez que a origem pretoriana da tutela seria a actio in factum, ${ }^{57}$ configura-se um lapso temporal em que ambas as ações coexistiram.

Uma vez diagnosticada a duplicidade formular da actio commodat $^{58}$, resta a indagação acerca de sua motivação, ou seja, o porquê de se necessitar, já se tendo uma tutela conferida pelo pretor, de uma outra ação civil, que a ela viria se unir.

Aresposta adviria da própria estrutura da actio in factum, a qual condicionava a condenação do comodatário à falta de restituição da coisa emprestada, de forma que não permitisse o acesso do juízo sobre as outras obrigações do comodatário, isto é, somente a obrigação de restituir a coisa emprestada é tutelada pela actio in factum, e não a obrigação de restituir a coisa de forma íntegra - sem danos - ou de não abusar do uso da coisa. Estas outras obrigações seriam incluídas dentro do amplo rol "oportere ex fide bona". 59

56 KASER, Max. Römisches Privatrecht. 6. ed. München: Beck, 1968. p. 154-155 (= § 40) e WEISS, Egon. Institutionen des römischen Privatrechts. 2. ed. Basel: Recht und Gaselldchaft, 1949. p. 348-340 $(=\S 96)$.

57 PASTORI, Franco. Il commodato... op. cit., p. XVIII, 2-3, lembra que, as actiones utiles são estranhas a esta matéria. Além disso, somente se compreende a introdução de uma mais restrita ação pretoriana, limitada ao "non reddere" no cabimento, se a ação civilística fosse posterior a esta, uma vez que se funda no mais amplo critério decisório da bona fides. O edito relativo ao comodato aparece no título D. 12, 1 ( "De rebus creditis"), enquanto ligado o instituto à actio in factum na medida em que a concepção do "credere" se refere à relação existente entre entrega e devolução da coisa. Mas, com a presença da fórmula in ius na actio commodati, esta também seria inserida no título "De bonae fidei iudicis". O motivo da presença da actio commodati neste último titulo seria justamente a tutela já conferida ao depósito, que processualmente se assemelha à duplicidade formular do comodato, na actio in ius, baseada igualmente na boa-fé, que seria mais antiga que a do comodato, condicionando a inclusão nesta rubrica edital que corresponderia a esta forma de juízo. Assim, também não se pode esquecer que a consideração substancial do comodato, a qual começa com sua aproximação do mútuo e do penhor na perspectiva das res creditae e termina com a inserção da relação por obra dos intérpretes na categoria dos contratos reais, apresenta como premissa uma amplíssima problemática de direito processual. No mesmo sentido BIONDI, Biondo. Istituzioni di diritto romano. Milano: Giuffrè, 1946. p. 360. SOLAZZI, Siro. Recensão... op. cit., p. 260, sustenta que a aproximação do comodato ao penhor e ao mútuo se dá pela conceito de "credere" e pela noção de "obligatio re contracta". Enfim, para ZANNINNI, Pierluigi. Comodato nel diritto romano. In: DIGESTO delle Discipline Privatistiche. Torino: UTET, 1998. v. 3, p. 32, é possível que o empréstimo de uso tenha gozado, antes da intervenção do pretor por meio da actio in factum, de uma proteção indireta do ius civile.

58 Um interessante posicionamento, embora em si óbvio, é colocado por MICHEL, Jacques. Gratuité en droit romain. Bruxelles: Université Libre de Bruxelles - Institut de Sociologie, 1962. p. 95-102 (=ns. 139-152). Segundo Jacques Michel só é cabível actio commodati se houver gratuidade na relação, pois, obviamente, não existe comodato que não seja gratuito. É um pressuposto lógico e até mesmo supletivo no raciocínio, uma vez que somente se fala em actio commodati quando exista uma relação que reuna todos os elementos essenciais - inclusive a gratuidade - para se configurar o comodato.

59 PASTORI, Franco. Il commodato... op. cit., p. XVIII. 
Assim, seria, para Franco Pastori, ${ }^{60}$ dentro da evolução histórica do comodato que se entenderia seu regime processual e material, o que envolveria o cabimento dos meios de tutela do comodato dentro do sistema de ações e sua sofrida recepção na área contratual, como traduz Paul. 29 ad ed., 13, 6, 17, 3, sendo também, neste sentido, que Gai. 4, 47, atribui ao comodato o fenômeno da duplicidade formular sobre a actio commodati ${ }^{61}$

Diferenciadas as duas ações, a in ius conceptae e a in factum conceptae, respectivamente, tutelas do ius civile e do ius honorarium, Franco Pastori62 ${ }^{2}$ sustenta que em alguns casos, como no depósito e no comodato, o pretor "et in ius et in factum conceptas formulas proponit".

Em outras palavras, as duas ações passam, portanto, a conviver, isto é, a serem aplicadas simultaneamente ao comodato, ${ }^{63}$ e a idéia da "duplicidade formular" surge para que, no caso concreto, os diversos critérios de responsabilidade - dolus, culpa e custodia ${ }^{64}$ - gozassem de eficácia plena.

A responsabilidade por custodia é figura típica e primitiva da responsabilidade objetiva do comodatário, e se aplica no contexto da formula in factum, vale dizer, não terá o juiz qualquer poder de examinar o comportamento do comodatário, condicionando a condenação ao "non reddere", à obrigação principal do comodatário, que é, justamente a da devolução da coisa emprestada. ${ }^{65}$ A aplicação, assim, da responsabilidade objetiva pela actio in factum decorre de sua própria estrutura, ou, mais corretamente, de sua própria intentio.

60 PASTORI, Franco. Il commodato...cit., p. XVIII-XIX: “L'evoluzione storica del commodato si propone quale questione fondamentale per interderne il regime processuale e sostanziale, in quanto essa coinvolge la collocazione dei mezzi di tutela del commodato nel contesto delle azioni e la sua sofferta recezione nell'area contrattuale, come sempra tradire il pensiero del giurista Paolo".

${ }^{61}$ Cf. Id. Ibid., p. 3. Embora a ideia utilizada seja de que a actio commodati directa, que tutela os direitos do comodante, tenha este caráter dúplice, não há porque negar que esta mesma estrutura esteja presente na actio commodati contraria, que cobra do comodante suas eventuais obrigações e deveres. Assim, cf. Id. Ibid., p. 448-454. Também PASTORI, Franco. Comodato... op. cit., p. 690, entende que a mesma duplicidade formular encontra-se no âmbito da actio commodati contraria, a qual, pela fórmula in factum estabelece a obrigação incondicionada do comodante de reembolsar o comodatário pelas despesas necessárias, enquanto pela fórmula in ius, baseada na bona fides, estabelece-se o ressarcimento do dano para o comodatário quando este se verificou por dolo do comodante. No mesmo sentido, ALVES, José Carlos Moreira. Direito Romano. Instituições de Direito Romano. Parte especial: direito das obrigações; direito de família; direito das sucessões. 6. ed. Rio de Janeiro: Forense, 2005. v. 2, p. 128 (= n. 231).

62 PASTORI, Franco. Il commodato... cit., p. 3. A busca pela gênese das duas fórmulas torna-se para F. Pastori, nas devidas proporções, uma neurose científica, por se tratar esta de um requisito básico para compreender a coexistência de multiplos critérios de responsabilidade e de como se relacionam os meios de tutela dos interesses do comodatário, o iudicium commodati contrarium.

63 PASTORI, Franco. Il commodato... cit., p. 2, entendendo que o reconhecimento jurídico do comodato enquanto típica figura contratual liga-se, assim, à tutela processual de ações concedidas em períodos diversos.

64 Cf. item 3. 2. (Culpa e custódia enquanto parâmetros de responsabilidade do comodatário), por inteiro, sobre a presença destes critérios de responsabilidade no comodato nas variadas fases do Direito Romano.

65 PASTORI, Franco. Comodato...cit., p. 690. 
Por outro lado, pela fórmula in ius sanciona-se as obrigações do comodatário de não abusar da coisa emprestada e de não a deteriorar, afirmando-se uma responsabilidade consoante com a bona fides, ou de natureza subjetiva. ${ }^{66}$

Porém, embora a tendência tradicional de se aceitar, com certa facilidade, a exclusão da formula in factum com o desenrolar do Direito Romano, por sua absorção pela actio in ius, não se deve pensar que aquela deixou de ser aplicada no direito justinianeu. ${ }^{67}$

A formula in factum, que já tinha convivido durante todo o período clássico com o regime jurídico do comodato e erigiu o conceito de "credere" [= "confiar algo a alguém, emprestar"], teria continuado a servir, segundo Franco Pastori, ${ }^{68}$ a uma função vital, uma vez que permite, ao contrário da fórmula de boa-fé, na falta de restituição da coisa emprestada, a aplicação sobre o comodatário da mais grave responsabilidade, vale dizer, da custodia.

Enfim, Franco Pastori ${ }^{69}$ afirma que, contra a minoria, representada por Emilio Betti e Giuseppe Ignazio Luzzatto, ${ }^{70}$ a formula in factum teria sancionado a obrigação de restituição da coisa emprestada ao se relacionar diretamente ao "reddere" [= "devolver, restituir", até mesmo no sentido de "compensar"], e a formula in ius sancionaria uma responsabilidade de natureza subjetiva, uniformizada pela bona fides, sendo utilizada não em relação à obrigação de restituição, mas apenas frente às obrigações do comodatário de não abusar ou de não deteriorar a coisa.

Para Giuseppe Ignazio Luzzatto ${ }^{71}$ não apenas a formula in factum, mas também a in ius deveria ser necessariamente sustentada sobre um "restituere" [=

$\overline{66}$ Cf. PASTORI, Franco. Comodato...cit., p. 690, segundo o qual a bona fides importa em uma aprofundada consideração por parte do juiz do comportamento pessoal do comodatário, comparando este com a conduta de uma pessoa correta. É justamente pela aplicação da bona fides que o comodante poderá exigir não somente o dano emergente, mas também os lucros cessantes.

67 Cf. Id. Ibid., p. 690.

68 PASTORI, Franco. Comodato (diritto romano). In: AZARA, Antonio. Novissimo Digesto Italiano. Torino: UTET, 1959. p. 690. Além disso, está em títulos diversos dos Digesta a tutela pela actio in factum e pela actio in ius, o que provoca, no período justinianeu a mesma duplicidade formular, com maior clareza, cf. PASTORI, Franco. Il commodato... cit., p. XVIII. Aliás, esta é uma peculiar diferença entre o comodato e o depósito. A formula in factum limitava a responsabilidade do depositário ao dolo, e deixa de ter uma função vital, frente à sucessiva fórmula baseada na boa-fé, mantendo-se com esta por mera inércia histórica, sendo, por fim, a tutela do depósito rubricada no edito "De bonae fidei iudiciis".

69 PASTORI, Franco. Sulla duplicità... cit., p. 89-94. A sobrevivência da actio in factum no período justinianeu, além de possibilitar a aplicação da responsabilidade objetiva ao caso concreto, demonstra o desejo do credor de fugir da realização da prova da existência da culpa por parte do comodatário, mesmo que sua indenização ficasse eventualmente limitada ao dano emergente. Continua-se a aplicar uma responsabilidade mais grave ao devedor do que a teoria apresenta.

70 LUZZATTO, Giuseppe Ignazio. «Commodati ... vel contra». In: LABEO: Rassegna di diritto romano. Napole: Jovene, 1955-. v. 2, p. 357.

71 Id. Ibid., p. 357. Segundo este autor, esta defesa de Franco Pastori foi esquecida por parte da maioria dos membros da banca do concurso, menos por Emilio Betti e Giuseppe Ignazio Luzzatto, para o qual Franco Pastori concorreu, atribuindo a este último a opinião de que toda obrigação do comodatário, e até o "restituere" 
"restabelecer, colocar no estado original"], sendo a afirmativa de Franco Pastori, que censura a possibilidade de se fundar uma ação contratual no "restituere", sem fundamento, já que toda obrigação do comodatário está inclusa no "oportere ex fide bona".

Giuseppe Ignazio Luzzatto $^{72}$ afirma que a fórmula não foi transmitida diretamente para nós, mas a fattispecie presente em Ulp. 28 ad ed., D. 13, 6, 5, 2-10, permitiria considerar segura a opinião hipotética de que a actio commodati seja estruturada em um fórmula análoga àquela que Gaio fez para a formula in ius da actio depositi, em Gai. 4, 47.

Através destes fragmentos observar-se-ia, antes de tudo, que, na própria formula in ius, a condenação era condicionada à falta de restituição da coisa, tornando insustentável a interpretação de Franco Pastori, segundo o qual o comodante agiria por meio da fórmula baseada na boa-fé quando já tivesse obtido a restituição da coisa, e desejasse agora conseguir o ressarcimento do dano sofrido pelo seu abuso ou/e por sua deterioração.

Assim, o objetivo da actio in ius seria, em primeiro lugar, também a restituição da coisa, ou seja, somente usando esta o comodante conseguiria a restituição da coisa e uma indenização por lucros cessantes, enquanto, pelo entedimento de Franco Pastori, precisaria-se entrar com a actio in factum para que a coisa fosse restituída, e depois com a in ius para conseguir uma indenização por eventual dano, o que seria desnecessário, moroso e com nítida falta de economia processual, para Giuseppe Ignazio Luzzatto.

Assim, tanto a actio in factum, como a "actio in ius", para Giuseppe Ignazio Luzzatto, ${ }^{73}$ desejavam em primeiro lugar a restituição da coisa emprestada. A maior elasticidade do juízo de boa-fé somente permitiria, ao lado do "restituere", uma consideração do conteúdo subjetivo do devedor.

Mas, se estas duas ações almejam, em primeiro lugar e antes de qualquer coisa, o "restituere", o credor poderia perder o interesse em preferir usar a formula in ius ou a in factum, uma vez que, de um lado, a deterioração da coisa era considerada como a falta da restituição, e, por outro lado, salvo na hipótese de força maior, adentrava-se a responsabilidade por custodia no âmbito desta última. As ações perdem assim qualquer distinção, não sendo desejo do credor usar a primeira em detrimento da segunda, e viceversa.

72 Id. Ibid., p. 359. A fórmula é, desta maneira, direta ao "quidquid dare facere oportet ex fide bona", mas no texto da condemnatio, ao lado da ordem dada pelo juiz, está a "exceptio "nisi restituat »".

73 LUZZATTO, Giuseppe Ignazio. «Commodati ... vel contra». In: LABEO: Rassegna di diritto romano. Napole: Jovene, 1955-.v. 2, p. 359. 
Este é o artifício de Giuseppe Ignazio Luzzatto ${ }^{74}$ para criticar a tese de excluir a responsabilidade por custodia dos iudicia bonae fidei, salvo os estabelecidos por Gaio, além da estranha situação na qual se encontraria o credor frente à possibilidade de mover qualquer uma das duas ações, ficando obrigado a se perguntar qual seria o comportamento do devedor frente ao objeto do comodato, antes de entrar com uma ou outra.

A correlação proposta por Franco Pastori entre a duplicidade formular e os critérios de responsabilidade acabou por ser igualmente atacada por Siro Solazzi, ${ }^{75}$ segundo o qual Franco Pastori também deveria ter dedicado algumas páginas sobre a aplicação da cláusula ex fide bona no âmbito da actio commodati.

Entretanto, o próprio Siro Solazzi ${ }^{76}$ releva o mérito de Franco Pastori terse detido no próprio sistema que ele construiu, desejando reforçar a tese de que a actio in factum sobreviveu no período justinianeu não por mera inércia histórica, mas por desempenhar uma função prática essencial, tanto que os compiladores, ao inserir a boa-fé no negócio jurídico do comodato, teriam se limitado a interpolar os fragmentos que os clássicos já descreviam sobre a formula in factum.

De fato, não há como negar a sobrevivência da fórmula in factum e também que o interesse da jurisprudência ao se dedicar a esta, mesmo com a presença da fórmula in ius, tenha sido grande. ${ }^{77}$

Mas, para Siro Solazzi,${ }^{78}$ a tese de Franco Pastori peca pela falta de citação de textos que se liguem à formula in factum e outros à formula in ius, pois somente assim se poderia avaliar as alterações pós-clássicas e justinianéias por ele afirmadas.

Por exemplo, Pomp. 11 ad Sab., D. 13, 6, 13 pr., ${ }^{79}$ supondo que o comodatário promete a devolução da coisa mais tarde novamente encontrada, ensina caber uma ação

74 LUZZATTO, Giuseppe Ignazio. «Commodati ... vel contra». In: LABEO: Rassegna di diritto romano. Napole: Jovene, 1955-.v. 2, p. 359-361. Para este autor a distinção sugerida por Franco Pastori de que a responsabilidade por custodia seria demandada pela actio in factum, enquanto esta somente objetivaria a restituição, e a formula in ius seria devota à responsabilidade subjetiva, prescindindo do "restituere" e se aplicando ao quidquid dare facere oportet ex fide bona, é inútil. Identificados os objetos das duas ações não existe, para Giuseppe Ignazio Luzzatto, a duplicidade formular.

75 SOLAZZI, Siro. Recensão a PASTORI, Franco, Il commodato nel diritto romano - Con contributi allo studio della responsabilità contrattuale. Milano: Giuffrè, 1954. IVRA: Rivista Internazionale di Diritto Romano e Antico, Napoli, v. 6, p. 258-270, 1955. p. 259-261.

76 Id. Ibid., p. 259-260. Por outro lado, as críticas de Siro Solazzi não são poucas. Em primeiro lugar, ele acredita que Franco Pastori, analisando os textos em que a bona fides foi introduzida pelos compiladores, não traz argumentos novos que sejam mais fortes ou mais fracos dos que já foram oferecidos antigamente. Critica ainda a existência de um paralelo exagerado entre o mútuo e o comodato, e entre a condictio e a formula in factum.

77 Id. Ibid., p. 259-260.

78 Id. Ibid., p. 260.

79 "Is qui commodatum accepit si non apparentis rei nomine commodati condemnetur, cavendum ei est, ut repertam dominus ei praestet". [= "Se o comodatário for condenado por causa do desaparecimento da coisa, ele deve dar caução de que, uma vez encontrada, a entregará ao comodante"']. 
pelo juízo de boa-fé, embora não se cite esta ação, uma vez que somente por este a condenação pode estar subordinada à prestação de cautiones.

A melhor mensagem da tese de Franco Pastori para Siro Solazzi ${ }^{80}$ é a exposição das funções que as duas fórmulas tem, pelas quais se busca uma tutela mais ampla da relação, podendo a tese ser resumida com a actio in factum tutelando a responsabilidade objetiva pela falta de restituição da coisa, enquanto pela actio in ius obtém-se o ressarcimento dos danos provocados na coisa ou dos abusos imputáveis ao comodatário.

O que não se pode negar na tese de Franco Pastori é, assim, a correlação existe entre as duas fórmulas das ações do comodato e as obrigações do comodato, bem como a sobrevivência da actio in factum no período justinianeu. ${ }^{81}$

Embora Pierluigi Zanninni ${ }^{82}$ entenda que não se saiba corretamente o funcionamento da duplicidade formular da actio commodati, Franco Pastori ${ }^{83}$ enuncia, tomando por base Gai. 4, 45-47, que da própria estrutura da formula, especialmente da intentio, algumas relações são sancionadas pela intentio in ius concepta, outras pela in factum conceptae. Por fim, existiriam as relações sancionadas concomitantemente pelas duas fórmulas, in ius et in factum conceptae.

No período justinianeu, segundo narra Biondo Biondi, ${ }^{84}$ a regra é de se exercitar uma ação até onde esta não concorre com a outra, podendo-se, assim, pedir a devolução pela actio in factum e os lucros cessantes através da actio in ius.

Havendo ou não necessidade de cumular as duas ações para obter a devolução da coisa e os lucros cessantes, pois com a actio in ius logicamente ambas as tutelas seriam

80 SOLAZZI, Siro. Recensão... cit., p. 261. Ele ainda critica a distinção oferecida por Franco Pastori entre o objetivo do comodato e o uso consentido pelo comodante da coisa. No entendimento de Siro Solazzi tratase de uma distinção imaginária, pois sendo o uso mais ou menos amplo, também assim será o objetivo do comodato (o objeto de um negócio jurídico é igualmente o objetivo que as partes vão perseguir). A tese de Franco Pastori se estrutura sobre Ulp. 28 ad ed., D. 19, 5, 17 pr. - "si gratuitam tibi habitationem dedero, an commodati agere possim?" -, onde acredita que o comodato não é conferido a um uso particular. Mas mesmo aqui o objetivo e o uso coincidem, pois a construção é dada com o objetivo de ser habitada e o comodatário não pode dela se servir para outro fim. Assim, "habitationem” determina o objetivo e o uso particular do edifício, que poderia ter destinações e servir para outros usos, como de um escritório, ou de uma loja. Não se pode negar que a palavra "habitationem" designa edifício destinado à habitação, pois seria uma interpolação caso a palavra se referisse à faculdade de habitar algum local. Uma vez admitido o comodato de imóveis, é certo que o comodato para uso de habitação não é em nada diferente deste.

81 Cf. SOLAZZI, Siro. Recensão... cit., p. 259-261.

82 ZANNINNI, Pierluigi. op. cit., p. 32.

83 PASTORI, Franco. Gaio... cit., p. 321. No entendimento de Franco Pastori, a partir da própria estrutura da intentio da actio in factum decorreria a aplicação da responsabilidade objetiva.

${ }^{84}$ BIONDI, Biondo. op. cit., p. 268. 
atingidas, ${ }^{85}$ o que importa é determinar qual o critério de responsabilidade que estas ações permitiriam ser aplicado ao caso concreto. ${ }^{86}$

Seja se afirmando que a responsabilidade objetiva se exerce por meio da actio in factum, ${ }^{87}$ ou mesmo pela actio in ius, ${ }^{88}$ os autores parecem ter se esquecido que fica aberta a oportunidade, que com facilidade seria negada, da responsabilidade por custodia poder ser efetivamente exercida no comodato em época justinianéia, não tendo sido engolida pelo critério da culpa ou da diligentia, uma vez que o aspecto processual teria permitido a aplicação de diversos critérios de responsabilidade ao comodatário.

\section{2. "Culpa" e "custodia" enquanto parâmetros de responsabilidade do comodatário}

Após o exame da duplicidade formular que se aplica à actio commodati, passa-se ao desenvolvimento do aspecto substancial da responsabilidade do comodatário, ou seja, por quais critérios de responsabilidade este respondia nas diversas fases históricas do Direito Romano, com foco principalmente na culpa e na custodia, enquanto parâmetros mais importantes da presente pesquisa.

Frente a cada uma das obrigações presentes no comodato e aos meios processuais para sua correta sanção, encontra-se espaço seguro para o questionamento da responsabilidade contratual no comodato. ${ }^{89}$

Assim, a responsabilidade do comodatário, longe de ser um pressuposto dogmático, seria uma concreta aplicação da duplicidade formular, o que demonstraria a existência de uma "linea logica di continuità" [= "linha lógica de continuidade"] entre as fórmulas concebidas, a responsabilidade e as obrigações do comodatário, que são as três premissas básicas para o entendimento do comodato, enquanto típica figura contratual, ou seja, sem estas não haveria como existir contrato juridicamente eficaz. ${ }^{90}$

Ponto de partida, no período clássico, ao se limitar ao aspecto mais importante do tema, a responsabilidade do comodatário conduz à figura da custodia, entendida como

\footnotetext{
85 Neste sentido a tese de LUZZATTO, Giuseppe Ignazio. Commodati... cit., p. 359, é logicamente plausível, já que ao demandar pelos danos causados à coisa, pede-se automaticamente sua devolução.

86 Cf. PASTORI, Franco. Il contratto... cit., p. 93.

87 PASTORI, Franco. Comodato... cit., p. 690.

88 Cf. LUZZATTO, Giuseppe Ignazio. Commodati... cit., p. 359-361. Poderia até se cogitar que, neste caso, para tutelar a responsabilidade objetiva, a actio in factum, que também é de direito estrito, teria importado alguns princípios da actio in ius, baseada na boa-fé.

89 Cf. PASTORI, Franco. Il contratto di comodato. Bologna: Cisalpino, 1997. p. 3.

90 Id. Ibid., p. 3-4. Este autor entende a evolução da responsabilidade do comodatário como gradual, continua e lógica frente ao desenvolvimento de uma relação que nasceu de normas sociais e se estendeu ao direito. Figuras abstratas como o dolo, a culpa, a responsabilidade objetiva, o risco contratual, dentre outras, codificadas pela linguagem jurídica moderna, encontrariam na fattispecie uma concreta aplicação dentro de uma específica realidade normativa.
} 
responsabilidade objetiva, e, no ponto de chegada, encontra-se a exactissima diligentia custodiendae rei. ${ }^{91}$

\section{2. 1. A responsabilidade do comodatário no período clássico}

A conhecida bipartição entre dolus - a má vontade de adimplir - e culpa negligência, imprudência ou imperícia - foi o instrumento utilizado pela ciência medieval para tentar reduzir a casuística do período justinianeu. ${ }^{92}$

Mas este instrumento é plenamente ineficaz quando, ao invés de se realizar uma busca neste, vai-se ao direito clássico, onde outros critérios de responsabilidade podem ser encontrados. ${ }^{93}$

O ponto de partida da responsabilidade do comodatário é a indiferença pelo elemento intencional, até mesmo por ignorância do devedor sobre a existência da obrigação. $^{94}$

Gai. 3, 206, afirma que o comodatário "custodiam praestat", ${ }^{95}$ vale dizer, ele incorre em uma responsabilidade objetiva, que supera o âmbito de responsabilidade do

91 Cf. a exegese de Gai. 2 aureor., D. 44, 7, 1, 4, no item 4, infra.

92 Cf. ARANGIO-RUIZ, Vincenzo. Istituzioni di diritto romano. 14. ed. Napoli: Jovene, 2006. p. 381.

93 Cf. Id. Ibid., p. 381-382. Segundo Vincenzo Arangio-Ruiz esta multiplicidade de critérios do direito clássico surge de um problema que não se percebe quando o objeto da obrigação é uma transmissão de dinheiro, de uma quantidade de coisas fungíveis ou de uma coisa indicada genericamente, como, por exemplo, em conseqüência de uma estipulação ou de um legado destes objetos, pois nenhum acontecimento pode ter tamanha força para tornar impossível o adimplemento ou para impedir o credor de agir contra a pessoa do devedor ou os bens destes, de acordo com o período histórico em que se encontrar. Nestes casos, nada mais se tem do que uma "dificuldade subjetiva de adimplir", ou seja, não propriamente uma "impossibilidade", sendo que, pelo princípio do comércio, esta dificuldade deve ser suportada pelo devedor. Esta só é encontrada em obrigações em que a propriedade transmitida é de uma coisa individualmente determinada. A impossibilidade material superveniente não representa por si uma causa de libertação do devedor. Enfim, o comodatário já responderia por dolus no período clássico.

94 Cf. Id. Ibid., p. 382. Os juristas romanos somente começaram a abrir exceções à medida que entendiam que certos resultados seriam absolutamente injustos. Foram nos numerosos contratos consensuais e reais, e em outros atos ilícitos por força dos quais alguém é obrigado a cuidar, custodiar, restituir coisa alheia ou que compete a outrem, como no caso do depósito, do comodato, do penhor, ou mesmo gerir os negócios alheios, como o mandato, a tutela e a gestão de negócios, que as indagações sobre o dano causado injustamente a alguém, e seus limites, foram desenvolvidas.

95 Cf. Id. Ibid., p. 383. As Gai Institutiones indicam duas das hipótese pela qual o devedor responde por custodia. Enquanto Gai. 3, 206, trata da hipótese do comodato, Gai. 3, 205, narra a entrega de roupas àquele que lava ou ao alfaiate, sendo que estas duas hipóteses podem ser estendidas à locatio operis faciendi, e, se as coisas locadas forem coisa móveis, a locatio rei utendae. A natureza desta obrigação, como as Gai Institutiones demonstram, está nas palavras "praestare custodiam”, e sua aplicação prática mais relevante, e conhecida, ocorre quando o devedor continua responsável se a coisa foi dele furtada, vale dizer, mesmo se o furto ocorreu por sua negligência.

Gai 3, 206: "Quae de fullone aut sarcinatore diximus, eadem transferemus et ad eum cui rem commodavimus. Nam ut illi mercedem capiendo custodiam praestant, ita hic quoque utendi commodum percipiendo similiter necesse habet custodiam praestare". [= "O que dissemos sobre o tintureiro ou o alfaiate, aplicaremos também ao comodatário. Desta forma, como aqueles respondem pela custódia da coisa recebida (mediante 
dolus e da culpa, e somente encontra limite na força maior, ou seja, nela se responde até mesmo por caso fortuito. ${ }^{96}$

A custodia somente pode ser entendida, neste contexto, em sentido técnico, como responsabilidade objetiva, e não em sentido atécnico, como simples atividade material de custodiar, que constitui obrigação do depositário, que apenas responde por dolus..$^{97}$

A responsabilidade por custodia do comodatário liga-se, assim, à actio in factum, que prevê a condenação por este não ter restituído a coisa recebida em empréstimo, prescindindo de qualquer avaliação subjetiva que pudesse justificar sua não-devolução. ${ }^{98}$

A consequência mais relevante da responsabilidade por custodia, pelas palavras de Gai. 3, 206, é que o dono da coisa emprestada não passa a ser mais legítimo

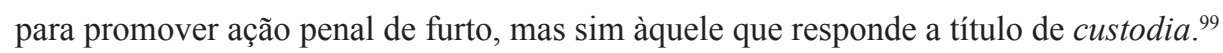

retribuição), também é indispensável que este, que recebe a coisa para usá-la a título de comodato, responda igualmente por custódia"].

96 PASTORI, Franco. Il commodato in diritto romano. 3. ed. Milano: Cisalpino, 1995. p. XIX, e PASTORI, Franco. Comodato... cit., p. 690-692. Conforme ARANGIO-RUIZ, Vincenzo. Istituzioni... cit., p. 381-383, o critério subjetivo de responsabilidade seria uma caminho ilegítimo para se encarar o direito clássico. Mas, por outro lado, Vincenzo Arangio-Ruiz acredita ser absolutamente impossível que o comodatário não respondesse, dentro de uma responsabilidade subjetiva, pelo dolus. As formulae in factum, seja do comodato, como do depósito, e as cláusulas do Edito, quando prometem novas ações, somente ressaltam que a responsabilidade sempre é convencionada sobre o dolus, isto é, as partes, seja devedor, seja credor, sempre respondem por dolus, não tendo esta regra sofrido qualquer alteração na hipótese da responsabilidade ser restrita ao dolus, ou não seja. Porém, mesmo antigamente, era considerado, como um problema que não se relacionava com esta regra, aquele relativo a "conservazione della cosa" confiada a uma das partes. A própria consciência social exigia que a parte pudesse contar com a restituição da coisa, ou porquê o contrato somente trouxesse lucros para o detentor - como no comodato - ou por outra razão qualquer, onde não se contentava de o considerar responsável apenas pela má vontade, pelo dolus. Para preencher este espaço, os juristas clássicos teriam criado a figura da custodia.

97 PASTORI, Franco. Il commodato... cit., p. XIX, e PASTORI, Franco. Comodato... cit., p. 690-692. Cf. também item 2 (Apresentação do Problema: a "Custodia” no Direito Romano), supra.

98 PASTORI, Franco. Il commodato... cit., p. XIX, e PASTORI, Franco. Comodato... cit., p. 690-692. O comodatário é obrigado pela coisa que lhe foi confiada mesmo se esta lhe foi furtada por terceiros, sendo que, a consequência desta situação, é que a actio furti lhe competirá, já que os efeitos do furto serão por ele suportados. O exemplo do furto é o caso típico de custodia em todo o Direito Romano, mas não o único. Assim, o desenvolvimento histórico do comodato propõe a formula in factum como prioritária frente à fórmula da boa-fé e gera a inclusão deste contrato no título "De rebus creditis" (D. 12, 1), como uma das ações de um juízo de sentido estrito, no mesmo patamar das condictiones que tutelam o mútuo e o penhor. A custodia tecnicamente compreendida, ou a responsabilidade objetiva do comodatário, mostra-se extremamente adequada com a estrutura peculiar da actio in factum, ação rigorosa que confere ao juiz o poder de absolver ou de condenar o comodatário conforme este tenha ou não devolvido a coisa a ele confiada.

99 ARANGIO-RUIZ, Vincenzo. Istituzioni... cit., p. 383. Embora no caso do comodatário sua responsabilidade por custodia coincida com a tutela da actio furti, nem sempre esta afirmação é verdadeira, ou seja, não é porque se pode usar a ação de furto que se responde por custodia, mas sim porque se responde por custodia que se pode usar a ação de furto. Assim, compete ao credor pignoratício a ação de furto, mas ele não responde por custodia. Em outras palavras, o simples cabimento da ação de furto não traz implícita a responsabilidade por custodia, nem a gera, mas quando uma das partes responde por custodia a ela cabe necessariamente a actio furti. 
Pode-se, segundo Vincenzo Arangio-Ruiz, ${ }^{100}$ sustentar que a responsabilidade por custodia também incluiria a hipótese de um terceiro que danificasse a coisa, ou quando o servo emprestado a título de comodato fugisse. ${ }^{101}$

Mas a discussão se aprofunda após as críticas de Siro Solazzi, ${ }^{102}$ que afirmam que existe a nítida possibilidade das Gai Institutiones terem sido glosadas.

Trata-se de opinião pacífica que nas fontes romanas não faltam "id est" ilegítimos, ou seja, colocados propositadamente pela glosa. Também se percebe, em frases, por exemplo, como " $A$ id est $B$ ", que o "id est" não se adequa à estrutura do texto, e os críticos acabam por tolher, apressadamente, a segunda parte - "id est $B$ " - sem se perguntar sobre a hipótese instigada pela primeira parte - " $A$ id est". O raciocínio deve ser, neste sentido, invertido, e muito instrutivo se demonstra Gai. 3, 204. ${ }^{103}$

Identificar o proprietário da coisa penhorada com o devedor é uma afirmativa falsa, embora esta seja a impressão que o "id est" transmite, já que este é sinônimo de igualdade entre dois termos ou orações. ${ }^{104}$

A falsidade é logicamente vista quando se percebe que pode ser dada uma coisa em penhor por débito alheio, o que nitidamente distingue o proprietário da coisa do devedor. A hipótese a ser trabalhada é justamente a do primeiro termo da expressão, vale dizer, "ipse dominus id est". ${ }^{105}$

Gai. 3, 203, ensina que a ação de furto "ei competit, cuius interest rem salvam esse, licet dominus non sit (...)" [= "A ação de furto compete a quem tenha interesse na conservação da coisa, ainda que não lhe seja o proprietário (...)”], e, a contrario sensu,

\footnotetext{
100 ARANGIO-RUIZ, Vincenzo. Istituzioni di diritto romano. 14. ed. Napoli: Jovene, 2006. p. 383.

101 No mesmo sentido, PASTORI, Franco. Comodato... cit., p. 690.

102 SOLAZZI, Siro. Una favola su Gai 3, 204. In: LABEO: Rassegna di Diritto Romano. Napole: Jovene, 1955 v. 3, 1957, p. 89-92. PASTORI, Franco. Gaio op. cit., p. 291-326, nega a possibilidade de glosa nos textos das Gai Institutiones sobre o comodato. Neste ponto, Siro Solazzi prefere se omitir, pois parte do raciocínio de que não se debruçará sobre os textos de Gaio apenas para rebater as observações feitas dos anti-críticos de Franco Pastori, mas somente escreverá sobre cada um destes quando tiver um argumento novo para apresentar. Portanto, neste ensaio, com o nome tão evocativo de "Una favola su Gai 3.204", Siro Solazzi somente pretende aplicar em Gai. 3, 204, o que tinha estudado sobre a possibilidade do “id est”" em Gai. 2, 35 , ser um glossema

103 Gai. 3, 204: "Unde constat creditorem de pignore subrepto furti agere posse; adeo quidem, ut quamvis ipse dominus, id est ipse debitor, eam rem subripuerit, nihilo minus creditori competat acto furti". [= "Por isso, é evidente que o credor (pignoratício) pode mover a ação de furto se a coisa apenhada lhe foi subtraída; a tal ponto que, se o próprio dono, isto é, o próprio proprietário, subtrair a coisa (apenhada), compete igualmente a ação de furto ao credor (pignoratício)"]. Para SOLAZZI, Siro. Una favola... cit., p. 91-92, Gaio não teria a necessidade de após o vocábulo "dominus" acrescentar "is est debitor", até porque, se o sujeito "dominus" não fosse claro o teria substituído por "debitor", eliminando qualquer incerteza ao se fazer uma equiparação.

104 SOLAZZI, Siro. Una favola... cit., p. 89, e SOLAZZI, Siro. La responsabilità del commodatario nelle Istituzione di Gaio. IVRA: Rivista Internazionale di Diritto Romano, Naplole, v. 6, p. 139-145, 1955. 139143.

105 Cf. SOLAZZI, Siro. Una favola... cit., p. 89, e SOLAZZI, Siro. La responsabilità... cit., p. 139-143.
} 
o próprio proprietário da coisa não pode agir, se não tiver interesse no momento pela conservação da coisa. ${ }^{106}$

O problema que interessa ser, agora, levantado é se Gai. 3, 206, poderia ter sido, da mesma forma que Gai. 3, 204, alvo de um glossema.

Siro Solazzi ${ }^{107}$ já tinha criticado a obra de Franco Pastori ${ }^{108}$ por falta de originalidade, uma vez que entende o "custodiam praestare" de Gai. 3, 206, como um critério técnico de responsabilidade objetiva, ou seja, uma tese já alcançada por Vincenzo Arangio-Ruiz ${ }^{109}$ e por Giuseppe Ignazio Luzzatto. ${ }^{110}$

Entretanto, o próprio Siro Solazzi ${ }^{111}$ não oferece qualquer paralelo concreto entre Gai. 3, 206, e Inst. 4, 1, 16: a única observação a ser extraída de Gai. 3, 206, para

${ }^{106}$ Cf. SOLAZZI, Siro. Una favola su Gai 3, 204. In: LABEO: Rassegna di Diritto Romano. Napole: Jovene, 1955-. v. 3, p. 89-90, e SOLAZZI, Siro. La responsabilità... cit., p. 139-143. Podia, assim, escolher, em Gai. 3, 204, entre as duas expressões "ipse dominus - ipse debitor", mas dizer "ipse dominus id est ipse debitor" não poderia fazer, sendo uma afirmação falsa. Para saber qual das duas expressões foi escolhida e acolhida, faz-se necessário analisar as duas qualidades, ou seja, a de proprietário e a de devedor, para se saber qual, neste contexto, merece maior relevo, e o que fará a balança da escolha pender para o lado do debitor. Ao declarar, em Gai. 3, 203-204, que a actio furti compete ao credor pignoratício, entende-se que cabe a parte não-proprietária da relação, sendo inútil dizer que esta ação seria exercida mesmo se a coisa tivesse sido furtada pelo próprio proprietário dela, uma vez que já é ensinamento de que comete furto o devedorproprietário que subtrai do credor a coisa penhorada. Existe, então, um motivo para chegar à conclusão que o ladrão no caso ostenta a qualidade de devedor, já que pela passagem está claro que o credor pignoratício pode mover a actio furti mesmo que o furto seja cometido pelo devedor, vale dizer, em um caso em que já munido de uma actio in personam contra o autor do furto, que, sendo o devedor, será provavelmente insolvente, o credor não tivesse interesse de adquirir uma outra coisa.

Este seria o motivo pelo qual o objetivo foi contrapor o debitor ao invés do dominus ao credor, como os justinianeus também entenderam em Inst. 4, 1, 14 - "etiamsi idoneum debitorem habeat, quia expedit ei pignori potius incumbere quam in personam agere". A única observação a ser feita é que "incumbit" é, com absoluta certeza, uma forma bizantina.

Estas observações demonstram que Gai. 3, 204, escreveu "adeo quidem, ut quamvis ipse debitor eam rem subripuerit, nihilo minus creditori competat actio furti", e um glosador comentou na palavra "debitor" que "id est ipse dominus", uma vez que já seria conhecida a lição veronense de "ipse dominus, id estipse debitor". Além disso, Inst. 4, 1, 14, diz que "adeo quidem ut, quamvis ipse debitor eam rem subripuerit, nihilo minus [...]", o que conclui que o exemplar de Gaio que estava na biblioteca justinianéia era diferente do veronense, pois o primeiro não foi mutilado pelas mãos dos glosadores. Desta forma, Gai. 3, 204, foi glosado, enquanto Inst. 4, 1, 14, não.

107 SOLAZZI, Siro. La responsabilità... cit., p. 139, e SOLAZZI, Siro. Recensão... cit., p. 258-262. Nesta última, Siro Solazzi refere-se à exposição de Franco Pastori como "debolissima".

108 PASTORI, Franco. Il commodato... cit., p. XIX.

109 ARANGIO-RUIZ, Vincenzo. Responsabilità... cit., p. 1-281.

${ }_{110}$ LUZZATTO, Giuseppe Ignazio. Caso fortuito... cit., p. 1-265.

111 SOLAZZI, Siro. La responsabilità... cit., p. 141-145. Aliás, ele não trata de Gai. 3, 206, mas apenas de Gai. 3, 205 e 207. Em Gai. 3, 205, Siro Solazzi encontra duas expressões que estariam em excesso: "quia ab eo dominus suum consequi non potest" e "quia hoc casu ipsius interest rem salvam", considerando a segunda, frente a Inst. 4, 1, 15, um glossema. Quanto ao texto de Gai. 3, 207, afirma-se que os editores acrescentaram à palavra "dolo" o adjetivo "malo", por influência de Inst. 4, 1, 17, e, a expressão "causa si" também decorreria das Iustiniani Institutiones. 
Siro Solazzi, ${ }^{112}$ é que o comodatário responde por custodia e seria legítimo para mover a actio furti.

Para Giuseppe Ignazio Luzzatto ${ }^{113}$ o único cuidado ao se interpretar Gai. 3, 206, é não desejar rotular a responsabilidade por custodia como sendo típica do comodatário, pois outras relações, como o fullo, o sarcinator ${ }^{114}$ e o receptum nautarum cauponum et stabulariorum, também respondiam objetivamente no direito clássico.

Que o período clássico teria sido marcado pela responsabilidade por custodia não se pode negar: a "responsabilità assoluta per determinati eventi" é a responsabilidade por custodia técnica, e vice-versa. ${ }^{115}$

112 SOLAZZI, Siro. Recensão a PASTORI, Franco, Il commodato nel diritto romano - Con contributi allo studio della responsabilità contrattuale, Milano, Giuffrè, 1954. IVRA: Rivista Internazionale di Diritto Romano e Antico, Napoli, v. 6, p. 258-270, 1955. p. 262.

113 LUZZATTO, Giuseppe Ignazio. Commodati... cit., p. 360.

114 Gai. 3, 205: "Item si fullo polienda curandaue aut sarcinator sarcienda uestimenta mercede certa acceperit eaque furto amiserit, ipse furti habet actionem, non dominus, quia domini nihil interest ea non periisse, cum iudicio locati a fullone aut sarcinatore suum consequi possit, si modo is fullo aut sarcinator rei praestandae sufficiat; nam si solvendo non est, tunc quia ab eo dominus suum consequi non potest, ipsi furti actio competit, quia, hoc casu ipsius interest rem salvam esse." [= "Também se o tintureiro recebe roupas para as polir e tratar, ou o alfaiate para as coser, em troca de determinada quantia financeira, e as perdem em razão de furto, compete a estes, e não ao proprietário (das roupas), a ação de furto, porque nenhum interesse tem este na conservação da coisa, uma vez que pode, pela ação de locação, obter uma indenização do tintureiro ou do alfaiate, se ao menos o (aquele; este) tintureiro ou alfaiate for capaz de garantir (a indenização da) a coisa; porém, se forem (o tintureiro ou o alfaiate) insolventes, então o proprietário não pode haver deles a indenização, competindo-lhe (ao proprietário) a ação de furto, já que, em tal caso, interessa-lhe conservar a coisa."].

Em outras relações ainda que indubitavelmente iudicia bonae fidei, como a compra e venda, a actio pigneraticia, o inspector, o depositário que voluntariamente se predispôs a guardar a coisa, e o precarista, a responsabilidade por custodia, para LUZZATTO, Giuseppe Ignazio. Commodati... cit., p. 360-362, também se faz presente. Para Giuseppe Ignazio Luzzatto, teria que ser explicado por Franco Pastori como se enquadra a responsabilidade do fullo, do sarcinator e do receptum nautarum - todos considerados pela jurisprudência clássica locatio operis - pela actio locati sem se utilizar do elemento da boa-fé desta última, ou, pelo sentido inverso, explicar como nunca a responsabilidade por custodia poderia ser compreendida nos limites da actio locati, sem que se recorra, pelos próprios princípios da locatio conductio à formula in factum, ao lado daquela in ius (como ocorre com a actio commodati). Até o momento em que não se tenha uma demonstração neste sentido, a explicação da dupla responsabilidade do comodatário através das duas fórmulas poderia estar condenada.

Para Giuseppe Ignazio Luzzatto a jurisprudência clássica em vez de recorrer a figuras abstratas, recorria a hipóteses concretas, como o fullo, o sarcinator, o carteiro e o ouvires, entre outros, também considerando outros critérios de responsabilidade, na casuística concreta, como aquela da imperitia e do vitium operis, ao lado da responsabilidade técnica por custodia. PASTORI, Franco. Il contratto... cit., p. 89-91, teria distorcido o direito clássico, pois jamais se negou a possibilidade da responsabilidade por custodia entrar no âmbito do juízo de boa-fé da actio locati, e muito menos duvidaram que a actio locati, mencionada em Gai. 3, 205, fosse a famigerada ação de boa-fé. A tentativa de destruir o testemunho de Gaio, por esta via, também se demonstra um artifício dialético. O importante é saber através de quais critérios vem regulada a responsabilidade na locação, nas várias relações do período clássico, e não saber se existe relação entre o juízo de boa-fé e responsabilidade por custodia, sendo que Franco Pastori tenta resolver o segundo problema, fugindo do mais relevante, que constitui o primeiro.

115 LUZZATTO, Giuseppe Ignazio. Caso fortuito... cit., p. 145. 
Sabe-se igualmente que a responsabilidade contratual no comodato tem como premissa histórica as Gai Institutiones, fundadas na obrigação de restituição do comodatário: ${ }^{116}$ estes textos falam da legitimidade ativa da actio furti do comodatário, ${ }^{117}$ que não pode substituir a coisa, pois lhe foi furtada, e de sua legitimidade passiva da actio commodati.

Infelizmente, não se apresentam registros suficientes para conspirar sobre um possível glossema em Gai. 3, 206, ou quem sabe uma alteração feita pelo próprio Gaio em seu texto original. ${ }^{118}$

Portanto, também no tema dos contratos, como já ocorria nos atos ilícitos, no direito clássico apresenta-se o "duplo sistema de responsabilidade por dolo e pela responsabilidade objetiva". Gaio, após fixar o conceito de "custodiam praestare", não o coloca em confronto com as hipóteses de responsabilidade por culpa, mas somente a relaciona com a responsabilidade do depositário, que não vai além do dolus. ${ }^{119}$

Não poderia haver, quanto à responsabilidade do comodatário no direito clássico, terceiro critério de responsabilidade baseado na culpa. Tanto que a palavra culpa ocorre apenas duas vezes nas Gai Institutiones - Gai. 3, 202 e 211 - e sempre com referência à actio legis Aquiliae, não à esfera contratual. ${ }^{120}$

${ }_{116}$ Cf. PASTORI, Franco. Il contratto di comodato. Bologna: Cisalpino, 1997. p. 89-90.

117 Para PASTORI, Franco. Il contratto... cit., p. 89-90, a posição dos artesãos, frente à legitimidade ativa na actio furti, é aproximada da posição jurídica do comodatário, e a responsabilidade destes devedores face ao credor se justificam pelo fato que os primeiros recebem um pagamento e o segundo usufrui do uso gratuito de uma coisa. De todas estas relações, e do que se depreende de Gai. 3, 107 e 207, o depósito diverge. O depositário "non praestat custodiam" e somente responde se agiu dolosamente. Logo, se independentemente de seu comportamento doloso, a coisa depositada the foi furtada, ele não responde pelo evento. Não goza assim o depositário do interesse de agir pela actio furti, que permanece com o proprietário da coisa, ao qual somente compete esta ação para ser ressarcido do furto. O depositário, no direito clássico, já respondia por custodia em sentido atécnico, o que demonstra a existência deste conceito antes mesmo do direito justinianeu.

118 Assim, o raciocínio desenvolvido por SOLAZZI, Siro. Una favola... cit., p. 89-92, sobre Gai. 3, 204, não pode ser estendido para outros textos desta sequência de Gaio. Da mesma forma, não se pode ampliar a suspeita levantada sobre Gai. 2 aureor., D. 44, 7, 1, 4, por ARANGIO-RUIZ, Vincenzo. Responsabilità... cit., p. 72-77, que este texto teria sido alterado primeiramente pelo próprio Gaio, quanto à Gai. 3, 206.

119 ARANGIO-RUIZ, Vincenzo. Istituzioni... cit., p. 383.

${ }^{120}$ Cf. Id. Ibid., p. 383-384. Aliás, Vincenzo Arangio-Ruiz entende que a palavra culpa utilizada por Gaio, quando trata da actio legis Aquiliae, apresenta o sentido de "nexo causal" entre a atividade voluntária do indivíduo e o dano produzido, ou seja, completamente diverso do sentido moderno. Por outro lado, Vincenzo Arangio-Ruiz nega a hipótese de a responsabilidade civil ter decorrido do furto, onde se enumeravam os casos em que o proprietário ou quem entregou a coisa somente respondia contratualmente se ele mesmo tivesse furtado a coisa, ou ele a tivesse deixado furtar.

Além disso, a inexistência de um cânone intermediário de responsabilidade - que seria a culpa - permaneceria na análise dos textos relativos à diligentia. No início da República e do Principado, mas também nos textos da jurisprudência que não foram manipulados pelos bizantinos, o termo diligentia exprime, para Vincenzo Arangio-Ruiz, como futura determinação da bona fides, a obrigação que incumbe as partes de exercitar uma atividade positiva. Mas, quando se vai avaliar o estado de ânimo do sujeito que omitiu a atividade, sempre se chega à conclusão que ele a omitiu por má vontade - por dolus -, e não por culpa. 
Assim, mesmos nos contratos em que se aplica a responsabilidade por custodia, o critério do dolus permanece como decisivo para todas as infrações em que não se teve a perda material da coisa, tratando-se de erro grosseiro dizer que em alguns contratos se responde por dolus e em outros por custodia: os critérios devem ser unidos. ${ }^{121}$

Com o tempo, surge a necessidade do comodante obter um ressarcimento pelas demais obrigações do comodatário, e, com este objetivo foi introduzido uma formula in ius, que necessitava de um juízo de boa-fé, uma vez que a condenação se referia não ao valor de mercado da coisa emprestada ("quanti ea res est"), como ocorria na defesa conferida pelo pretor, mas sim ao montante da condenação, que permitia a valorização do específíco interesse do autor ("quidquid ob eam rem dare facere oportet ex fide bona"). ${ }^{122}$

Por um lado, a formula in factum, a obrigação de restituição e a responsabilidade por custodia, e, por outro lado, a formula in ius, a tutela de todas as demais obrigações do comodatário para que o comodante fosse devidamente ressarcido, uma vez que se analisa diretamente a conduta do devedor, do comodatário. ${ }^{123}$

Além disso, embora a tendência da responsabilidade subjetiva no período justinianeu seja dificilmente contestável, ou seja, uma responsabilidade do comodatário entre os limites da diligentia, ${ }^{124}$ isto não significa que os clássicos, mesmo em período tardio, não tenham operado alguma valorização da diligentia, de forma um tanto diversa: considerandoa aquele aspecto concreto da bona fides e não uma figura autônoma de responsabilidade.

Max $\operatorname{Kaser}^{125}$ constata que ao fim do período clássico do Direito Romano o comodato passaria por um "fenômeno de enfraquecimento", ${ }^{126}$ que não tardaria para

121 ARANGIO-RUIZ, Vincenzo. Istituzioni... cit., p. 384. Assim, para se saber se em um contrato, durante o período clássico, em que a conservação da coisa alheia é devida pelo devedor, responderia este, em determinada situação ou circunstâncias, por dolus ou por custodia, deve-se aplicar a seguinte "regra (prática)": se ocorrer a perda material da coisa, responde o devedor por custodia, mas, no caso contrário, de não ocorrer a perda material da coisa, responde este por dolus. O dolus é um princípio geral de responsabilidade civil das partes.

122 Cf. PASTORI, Franco. Il commodato... cit., p. XIX-XX, e PASTORI, Franco. Comodato op. cit., p. 690-692. Essa necessidade teria ocorrido mesmo com a ampliação do âmbito da actio in factum: fundada sobre o "reddere" - "eamque redditam non esse" é a expressão que condiciona a condenação - permitiu sancionar uma obrigação diversa daquela de restituição da coisa, como, por exemplo, a devolução da coisa com danos ou de não abusá-la no uso.

123 Id. Ibid., p. XX, e PASTORI, Franco. Comodato... cit., p. 690-692.

124 Cf. PASTORI, Franco. Il commodato... cit., p. 267, e PASTORI, Franco. Comodato... cit., p. 690-692.

125 KASER, Max. Das römische Privatrecht-Die nachclassischen Entwicklungen. 2. ed. München: Beck, 1975. v. 2 , p. $271(=\S 262)$.

126 Cf. Id. Ibid., p. $271(=\S 262)$. O commodatum perderia plenamente, segundo Max Kaser, o seu perfil no período justinianeu, uma vez que seu próprio conceito, como "uso", "cessão" ou "concessão" da coisa a um terceiro, sofreria uma grande restrição. Esta diminuição do conceito - mais propriamente de objeto do comodato - seria decorrência, em regra, de quatro desdobramentos. O perfil do comodato começa a desaparecer, primeiramente, quando o "Geldleihe" [= "empréstimo de dinheiro"] é transferido para a típica figura do mútuo, como claramente se pode observar em C. Th. 2, 31, 1, e Honor et Theodos., C. 4, 26, 13 pr. [de 422 d.. C.]. Trata-se de um fenômeno que seria plenamente natural, com influência segura ou pelo menos 
atingir a esfera da responsabilidade contratual, especialmente, do comodatário, onde, por seu reflexo, a clássica responsabilidade por custodia seria igualmente enfraquecida pelo critério da culpa. Um fenômeno tardio no período clássico, mas mesmo assim anterior ao pós-clássico.

\section{2. 2. O período pós-clássico: a convivência da "custodia" com a "culpa"}

\section{É certo que dentro do Corpus Iuris Civilis existem diversos textos que refletem} as tendências do direito pós-clássico, e, justamente por estarem em contraste nítido com os princípios justinianeus, devem ser interpretados dentro dos princípios originários. ${ }^{127}$

Quanto à responsabilidade do comodatário, a mensagem do direito justinianeu assenta-se na figura da exactissima diligentia de Gai. 2 aureor., D. 44, 7, 1, 4, que, por definir a responsabilidade do comodatário, poderia igualmente ser usada como critério interpretativo dos textos nos quais vem citada a diligentia, ou a culpa. ${ }^{128}$

É esta nova perspectiva compilatória e legislativa do direito justinianeu que permitiria dizer quais seriam os textos interpolados, e demonstraria que a menção de qualquer outra forma de responsabilidade do comodatário, sem ser a baseada na exactissima diligentia, seria mera evocação histórica. ${ }^{129}$

Ao lado da custodia, vem apresentada, ao mesmo tempo, outras figuras de responsabilidade, como o dolus e a culpa, o que demonstraria ser evidente que originalmente somente se mencionava a primeira, e apenas depois foi acrescida a figura da culpa. ${ }^{130}$

provável do direito germânico, especialmente através de seu juramento. A segunda parcela que enfraqueceu o instituto jurídico do comodato foi por meio dos contratos da locação e do arrendamento, onde ocorre uma "concessão" remunerada da coisa para uso ou fruição alheia. O terceiro desdobramento ocorreu com o instituto jurídico do precarium, que ao se tornar obrigatório, concebe geralmente um contrato abstrato remunerado. A quarta e última etapa do enfraquecimento da figura jurídica do comodato ocorre finalmente com o "Hinterlegung" [= "depósito"]. Mútuo, locação, arrendamento, precarium e depósito se tornariam as figuras centrais neste processo ou fenômeno de enfraquecimento do comodato, isto é, este foi enfraquecido através de outros contratos, e, logo, influenciaria na típica responsabilidade por custodia do comodatário.

127 Cf. PASTORI, Franco. Il commodato... cit., p. 299. Estes textos, em especial Ulp. 38 ad ed., D. 13, 7, 13, 1, Ulp. 28 ad ed., D. 13, 6, 5, 5, 13 e 15, e Paul. 5 ad Sab. D. 18, 6, 3, seriam, no entendimento de Franco Pastori, por si tão evidentes, que, ao evocarem uma forma mais antiga de visão sobre a responsabilidade, não poderiam ser obras dos compiladores, os quais, por sua vez, apenas os acolheram sem quaisquer modificações.

128 Cf. PASTORI, Franco. Il commodato... cit., p. 299. Cf. exegese de Gai. 2 aureor., D. 44, 7, 1, 4, no item 4, infra.

129 Cf. Id. Ibid., p. 299. Se, por um lado, Franco Pastori tem absoluta razão em sustentar que o critério da exactissima diligentia de Gai. 2 aureor, D. 44, 7, 1, 4, pertence ao período justinianeu, o mesmo não ocorre, por outro lado, ao concentrar todo esta fase neste texto, uma vez que na compilação também os textos tratam de uma custodia técnica, como em Ulp. 28 ad ed., D. 13, 6, 5, 3-4. Mas, de qualquer forma, para ele, quando os compiladores justinianeus falam apenas de diligentia, esta deve ser entendida como exactissima diligentia. $\mathrm{O}$ autor acredita que esta interpretação seja possível, uma vez que os textos pré-justinianeus mencionam a diligentia e, assim, apresentam a possibilidade de a interpretar de forma consoante com a nova tendência.

130 Cf. PASTORI, Franco. Il commodato... cit., p. 299-300. É o caso de Ulp. 38 ad ed., D. 13, 7, 13, 1, o qual sustenta que tanto na actio pignoraticia, quanto na actio commodati directa, a responsabilidade do devedor é 
Pode-se, assim, determinar a introdução definitiva da culpa, como critério de responsabilidade do comodatário, no período pós-clássico do Direito Romano. ${ }^{131}$ PS. 2, 4, 3, ${ }^{132}$ e Modest., Coll. 10, 2, 1 e 4, ${ }^{133}$ demonstram que a originária custodia vem aproximada sucessivamente da responsabilidade baseada na culpa ou na

ligada a figura do dolus, da culpa e da custodia. Ademais, Franco Pastori acredita que ao se aproximar a culpa da custodia, esta não poderia mais ser entendida no sentido técnico, mas apenas no atécnico.

131 Cf. PASTORI, Franco. Il commodato... cit., p. 300. Embora a introdução efetiva somente deve ter ocorrido no direito pós-clássico (pré-justinianeu), não se pode esquecer que já no fim do período clássico, muito provavelmente a actio in ius já operava uma duplicidade formular na actio commodati directa, o que já possibilitava um julgamento conforme um juízo subjetivo. Cf. item. 3. 2. 1, supra.

Em um sentido muito semelhante, LUZZATTO, Giuseppe Ignazio. Caso fortuito... cit., p. 145-146, ao tratar desta segunda fase de evolução da responsabilidade do comodatário - a primeira é justamente a responsabilidade por custodia no período clássico -, acredita que o texto fundamental, no direito pósclássico, é o de C. Th. 2, 31, 1, onde seria possível perceber uma responsabilidade subjetiva genérica por culpa ou diligentia, mas ainda sem qualquer graduação, principalmente, sem se falar de uma exactissima diligentia, que seria alcançada apenas na última fase de evolução da responsabilidade do comodatário, no período justinianeu. Esta evolução da responsabilidade do comodatário, encontraria consonância direta, para Giuseppe Ignazio Luzzatto, no desenvolvimento de uma teoria do caso fortuito: no período clássico, apenas existia a indagação direta se determinado evento concreto estava contido ou não na responsabilidade objetiva do devedor, enquanto na fase pós-clássica, em correlação à responsabilidade culposa do devedor existia uma categoria genérica do caso fortuito, que limitava diretamente os limites da responsabilidade subjetiva do agente. Porém, apenas no período justinianeu iria se configurar uma diferença entre casus maior e casus minor, que funcionava para determinar também a diferença entre diligentia (exacta) e diligentia diligentissimi patrisfamilias (exactissima).

C. Th. 2, 31, 1: "Dominos ita constringi manifestum est actione praetoria, quae appellatur quod iussu, si certam numerari praeceperint servo actorive pecuniam. Igitur in perpetuum edictali lege sancimus, ut, qui servo, colono, conductori, procuratori actorive possessionis pecuniam commodat, sciat, dominos possessionum cultoresve terrarum obligari non posse. Neque familiares epistulas, quibus homines plerumque commendantur absentium, in id trahere convenit, ut pecuniam quoque, quam non rogatus fuerat, inpendisse se pro praediis mentiatur, cum, nisi specialiter ut pecuniam commodet, a domino fuerit postulatus, idem dominus teneri non possit; creditaque quantitate multari volumus creditores, si huiusmodi personis non iubente domino, nec fideiussoribus specialiter acceptis fuerit commodata pecunia". [= "É certo que os proprietários (= credores) venham mover a actio pretoriana denominada quod iussu (= "por causa do que autoriza") (contra o possuidor ou ausente), se tivessem emprestado uma determinada soma de dinheiro ao escravo, ou ao representante (do possuidor ou ausente). Sancionamos com a presente lei edital in perpetuum, por exemplo, quem entrega dinheiro a título de comodato ao escravo, colono, locatário, procurador ou representante do possuidor, sabendo que os possuidores ou cultores da terra não podem se obrigar. E nem as cartas familiares, com que frequentemente se confia em um ausente, podem ser interpretadas no sentido que ele também afirma ter gasto todo o dinheiro, o qual não foi pedido, não podendo este senhor ser obrigado, se não tiver expressamente pedido emprestado o dinheiro. E desejamos que os credores sejam multados pela quantidade emprestada, se o dinheiro for dado para estas pessoas sem a ordem do senhor e sem ter recebido especiais fidejussores"]. Texto em latim de MEYER, Paulus Martin; MOMMSEN, Theodorus. Theodosiani - Libri XVI - Cvm constitvtionibus sirmondianis, 1971.

132 "Servus uel equul a latronibus uel in bello occisi, si in aliam causam commodati sunt, actio commodati datur: custodia enim et diligentia rei commodatae praestanda est." [= "O escravo ou o cavalo mortos por ladrões ou na guerra, se por qualquer outra causa foram entregues em comodato, dá-se lugar à actio commodati (directa): na realidade (o comodatário) responde tanto por custódia como por diligência".]. Texto em latim de Baviera, Johannes. FIRA II.

No mesmo sentido, SOLAZZI, Siro. Recensão... cit., p. 263, considera a frase "custodia enim et diligentia rei commodatae praestanda est” de PS. 2, 4, 3, espúria, em razão da palavra "diligentia”.

133 Modest., Coll. 10, 2, 1: "Commodati iudicio conuentus et culpam praestare cogitur: qui uero depositi 
diligentia, que relembram muito o discurso também presente em Ulp. 38 ad ed., D. 13, 7, $13,1 .{ }^{134}$

Ulp. $28 \mathrm{ad}$ ed., D. 13, 6, 5, 15, ${ }^{135}$ é outro fragmento que faz referência à responsabilidade técnica por custodia, também apresentada conjuntamente com figuras de responsabilidade subjetiva, ou seja, o dolus, a culpa e a diligentia. Basta a afirmação que o comodatário "et dolum et culpam et diligentiam et custodiam praestare debet".

Desta forma, sendo a custodia a figura de responsabilidade mais antiga, as demais figuras aparecem como uma necessidade de se unirem posteriormente a ela. ${ }^{136}$

convenitur, de dolo, non etiam de culpa condemnandus est. Commodati enim contractu, quia utriusque contrahentis utilitas intervenit, utrumque praestatur: in depositi vero causa sola deponentis utilitas uertitur et ibi dolus tantum praestatur". [= "Pelo juízo do comodato, cogita-se um acordo para responder por culpa. $\mathrm{Na}$ verdade, quem convenciona um depósito, é condenado (apenas) por dolo, mas não pela culpa. É certo que pelo contrato de comodato os contratantes respondem (por dolo e culpa), uma vez que ambos detém interesse. No depósito, (pelo contrário,) a utilidade, na realidade, é concebida apenas em razão do depositante e então a responsabilidade é somente por dolo"].

Modest., Coll. 10, 2, 4: "Depositi damnatus infamis est: qui uero commodati damnatur, non fit infamis: alter enim propter dolum, alter propter culpam condemnatur." [= "O condenado na ação de depósito fica infame, (mas) quem é condenado na ação de comodato não (fica infame). É certo que o primeiro é condenado em razão do dolo, (enquanto que) o segundo (é condenado) em razão da culpa”]. Textos em latim de BAVIERA, Johannes. FIRA II.

134 "Venit autem in hac actione et dolus et culpa, ut in commodato: venit et custodia: vis maior non venit". [= "Mas se compreende nesta ação (do penhor) tanto o dolo como a culpa, como no comodato; e também se compreende a custódia, mas não a força maior.’'].

PASTORI, Franco. Il commodato... cit., p. 300. Este texto de Ulpiano torna-se relevante, primeiramente, por não se encontrar entre a sedes materiae do comodato, isto é, no título “Commodati [vel contra]" (D. 13, 5), e, depois, por trazer um discurso sobre a responsabilidade do comodatário sancionado pelo sistema justinianeu.

135 "Si duobus vehiculum commodatum sit vel locatum simul, Celsus filius scribit "scripsit" libro sexto digestorum quaeri posse, utrum unusquisque eorum in solidum an pro parte teneatur. Et ait duorum quidem in solidum dominium vel possessionem esse non posse: nec quemquam partis corporis dominum esse, sed totius corporis pro indiviso pro parte dominium habere. Usum autem balinei quidem vel porticus vel campi uniuscuiusque in solidum esse (neque enim minus me uti, quod et alius uteretur): verum in vehiculo commodato vel locato pro parte quidem effectu me usum habere, quia non omnia loca vehiculi teneam. Sed esse verius ait et dolum et culpam et diligentiam et custodiam in totum me praestare debere: quare duo quodammodo rei habebuntur et, si alter conventus praestiterit, liberabit alterum et ambobus competit furti actio". [= "Se tivesse entregado em comodato um veículo para duas pessoas (ou um arrendamento conjunto), Celso filho escreve, no livro sexto do Digesto, diz que poderia se perguntar: Ficará por acaso cada um deles obrigado pelo todo, ou cada um por sua parte? E diz que, sem dúvidas, não pode ser de ambos o domínio por inteiro ou a posse, nem qualquer ser senhor de parte da coisa, sem que tenha em parte o domínio de toda a coisa sem dividir. Porém, na verdade, o uso de um banho, de um pórtico, ou de um campo, é inteiramente de cada um (porque um usa tanto quanto o outro). Mas quanto ao veículo entregue em comodato (ou em arrendamento), acredito certamente que o uso seja parcial, porque ninguém ocupa todos os lugares do veículo. Diz que é mais certo que devo responder pelo todo por dolo, culpa, diligência e custódia, pelo qual estarão os dois obrigados de certo modo pelo todo, e ao se demandar um e estiver satisfeito, livrar-se-á o outro. A ambos compete a ação de furto".].

136 Embora PASTORI, Franco. Il commodato di diritto romano. Milano: Cisalpino, 1995. p. 300, refira-se ao dolus, já ficou comprovado, pela tese de ARANGIO-RUIZ, Vincenzo. Istituzioni... cit., pp. 383-384, que este já constituía um critério autônomo de responsabilidade do comodatário desde o período clássico. $\mathrm{O}$ próprio Franco Pastori acredita que o jurista clássico de Ulp. 28 ad ed., D. 13, 6, 5, 15, não se limitaria a ter mencionado a custodia, colocando ao lado desta o dolus. 
A tendência do Direito pós-clássico parece desejar considerar a responsabilidade do comodatário entre os limites da culpa e da diligentia, mas ainda sem construir diversas graduações destas, ou mesmo se esquecer absolutamente da custodia. ${ }^{137}$

Mas também é improvável que os juristas pós-clássicos, antes do período justinianeu, teriam mencionado ao mesmo tempo a culpa e a diligentia, uma vez que para eles tais figuras eram sinônimas, não apresentando, assim, motivo para a menção de ambas. ${ }^{138}$

Também Ulp. 28 ad ed., D. 13, 6, 5, 5, ${ }^{139}$ ao sustentar "custodiam plane commodatae rei etiam diligentem debet praestare", demonstraria uma distorção da responsabilidade por custodia com sua aproximação da diligentia, concepção própria do direito pós-clássico e que precede a inutilização da custodia enquanto figura típica de responsabilidade com o aparecimento da diligentia exactissima in custodiendo. Esta última figura surgiria da colocação da diligentia dentro da custodia, o que teria alterado o fundamento desta. ${ }^{140}$

Como este texto, Paul. 5 ad Sab., D. 18, 6, 3, ${ }^{141}$ também incluiu a figura da diligentia na custodia, mas neste texto não aparece uma simples diligência, mas um grau elevado desta - “... ut diligentiam praestet exactiorem, quam in suis rebus adhiberet" -, sendo, portanto, evidente a intervenção dos compiladores. ${ }^{142}$

Fica explícito o traço, por estes dois últimos textos, próprio do direito pósclássico, da menção conjunta da diligentia e da custodia, e, ademais, ao contrário dos demais textos, por ambos, já fica clara a tendência de fundir estas duas figuras, que somente se completará mais recentemente com a figura da exactissima diligentia in custodiendo. ${ }^{143}$

137 PASTORI, Franco. Il commodato... cit., p. 300.

138 Cf. PASTORI, Franco. Il commodato... cit., p. 300-301. Para Franco Pastori, ao inserirem o vocábulo diligentia, enquanto sinônimo de culpa, os compiladores desejaram colocar em destaque uma responsabilidade que já operava no direito pós-clássico. Para SOLAZZI, Siro. Recensão... cit., p. 264, em Ulp. 28 ad ed., D. 13, 6, 5,15 , enquanto a palavra diligentia teria sido inserida pelos compiladores, e as palavras "dolus" e "culpa" pelos pós-clássicos. Mas não se sabe, com certeza, quem escreveu “sed esse verius ...”.

139 "Custodiam plane commodatae rei etiam diligentem debet praestare". [= "Sem dúvidas (o comodatário) deve responder pela custódia e pela diligência da coisa entregue em comodato"].

140 Cf. PASTORI, Franco. Il commodato... cit., p. 300-301.

141 "Custodiam autem venditor talem praestare debet, quam praestant hi quibus res commodata est, ut diligentiam praestet exactiorem, quam in suis rebus adhiberet". [= "O vendedor (porém) deve responder por uma custódia tal qual respondem os comodatários, de forma que responda pela mais exata diligência, que teria com suas próprias coisas".]

142 Cf. PASTORI, Franco. Il commodato... cit., p. 301.

143 Cf. PASTORI, Franco. Il commodato di diritto romano. Milano: Cisalpino, 1995. p. 301-303. No mesmo sentido, LUZZATTO, Giuseppe. Caso fortuito... cit., p. 146. Por outro lado, tanto Franco Pastori, como Giuseppe Ignazio Luzzatto, demonstram dúvidas se a alteração teórica da responsabilidade por custodia, do período clássico, para a responsabilidade baseada na exactissima diligentia, da fase justinianéia, teria efetivamente surtido efeito na prática. Segundo SOLAZZI, Siro. Recensão... cit., p. 263-264, a custodia e a exactissima diligentia são praticamente a mesma coisa, uma vez que a variação é muito mais formal e teórica do que pragmática.

Para PASTORI, Franco. Il commodato... cit., p. 303, as mesmas observações feitas quanto aos textos de 
Todos estes textos demonstram, claramente, concepções da responsabilidade pós-clássica, e, continuamente, referem-se aos critérios esboçados em PS. 2, 4, 3, onde a diligentia, antítese da "neglegentia, que, por sua vez, compõe a culpa, apresenta-se como uma responsabilidade unida - ao lado da - à custodia. ${ }^{144}$

Em Modest., Coll. 10, 2, 1 e 4, a palavra custodia é substituída pelo substantivo culpa, e, com absoluta certeza, não se pode duvidar que, mesmo na Collatio legum Mosaicarum et Romanorum, o texto original apresentava a responsabilidade por custodia, o que se deduz da Modest., Coll. 10, 2, 6, ${ }^{145}$ no qual, como em Gai. 3, 206, a legitimação da actio furti continua a ser do comodatário, sendo que esta somente pode-se fundamentar na premissa de uma responsabilidade objetiva da devolução da coisa emprestada. ${ }^{146}$

Ulp. 13, 6, 5, 5, e Paul. 5 ad Sab., D. 18, 6, 3, valem para Ulp. 28 ad ed., D. 13, 6, 5, 9, onde o comodatário "diligentiam praestat" pela entrega a ele da coisa emprestada, assim como os antigos sustentavam nesta hipótese que o comodatário respondia por custodia. Também aqui percebe-se a menção da diligentia ao lado da custodia. Todos estes critérios também são encontrados em Ulp. 28 ad ed., D. 13, 6, 5, 13, o qual narra a possibilidade de emprestar um escravo em comodato conjuntamente com um prato. O escravo teria a função de garçom e a ele seria confiado o prato. Cartilio sustenta que o comodatário deve suportar o periculum até mesmo em relação ao prato, ou seja, substancialmente, tratar-se-iam de dois comodatos, um cujo o objeto seria o escravo, e outro cujo o objeto seria o prato. Neste texto a palavra "periculum" tomou também o lugar da "custodia", uma vez que ocorre referência à obrigação de restituição da coisa emprestada, e, logo, o jurista clássico faria menção à custodia em sentido técnico. Por isso, seria impossível que Cartilio e Ulpiano acrescentassem "quare culpam in eam quoque praestandam", colocando, contra qualquer lógica, um critério inconciliável com a responsabilidade objetiva. Logo, esta frase inteira faria referência a uma mentalidade pós-clássica, que aproximava a responsabilidade por custodia da diligentia e da culpa, para tentar, talvez sem conseguir, "conciliare il regime classico con le nuove tendenze". Não restam dúvidas de que tenha ocorrido uma interpolação pós-clássica nesta frase e que a palavra "culpam" substituiu, antes da compilação justinianéia, "custodia" ou "periculum", aqui entendidos como sinônimos. Também se sustenta que ocorreu uma interpolação na frase "nisi fugae praestitit culpam", que se refere à limitação da responsabilidade por custodia, no direito clássico, à fuga de escravos.

${ }_{144}$ Cf. PASTORI, Franco. Il commodato... cit., p. 303.

145 "Res deposita si subripiatur, dominus dumtaxat habet furti actionem, quamvis eius apud quem res deposita est intersit ob inpensas in rem factas rem retinere. Is uero cui res commodata sit furti experiri debebit, si modo solvendo fuerit". [= "Se a coisa depositada for furtada, somente o seu dono tem a ação de furto, pois, sem dúvida, é o depositante que tem interesse quanto à manutenção das despesas realizadas na coisa depositada. É certo (porém) que o comodatário tem que mover a ação de furto, a fim de adimplir sua obrigação. "]. Texto em latim de BAVIERA, Johannes. FIRA II.

${ }^{146}$ Cf. PASTORI, Franco. Il commodato op. cit., p. 303. Ele ainda acredita que Modest., Coll. 10, 2, 1 e 4, apresentam uma evolução frente a PS 2, 4, 3, pois enquanto neste ao regime clássico da custodia somente foi juntado ao regime pós-clássico da diligentia" no primeiro tem-se a superação da responsabilidade por custodia, como consolidação do regime pós-clássico, ou seja, de um sistema contratual baseado na responsabilidade culposa. 


\section{À esta concepção da Collatio Legum Mosaicarum et Romanorum une-se}

Ulp. 29 ad ed., D. 50, 17, 23. ${ }^{147}$ Mas, este último, não apresenta qualquer substrato do texto original. ${ }^{148}$

147 "Contractus quidam dolum malum dumtaxat recipiunt, quidam et dolum et culpam. Dolum tantum: depositum et precarium. Dolum et culpam mandatum, commodatum, venditum, pignori acceptum, locatum, item dotis datio, tutelae, negotia gesta: in his quidem et diligentiam. Societas et rerum communio et dolum et culpam recipit. Sed haec ita, nisi si quid nominatim convenit (vel plus vel minus) in singulis contractibus: nam hoc servabitur, quod initio convenit (legem enim contractus dedit), excepto eo, quod Celsus putat non valere, si convenerit, ne dolus praestetur: hoc enim bonae fidei iudicio contrarium est: et ita utimur. Animalium vero casus mortesque, quae sine culpa accidunt, fugae servorum qui custodiri non solent, rapinae, tumultus, incendia, aquarum magnitudines, impetus praedonum a nullo praestantur". [= "Alguns contratos admitem somente dolo, e outros, (admitem) dolo e culpa. Somente por dolo, o depósito e o precário; por dolo e culpa, o mandato, o comodato, a compra e venda, o recebimento do penhor, a locação, e também a dação do dote, da tutela e a gestão de negócios: nestes (últimos) certamente se responde também por diligência. A sociedade e a comunhão de bens admitem tanto o dolo como a culpa, mas é assim caso não se convencionar algo diverso (para mais ou para menos) em cada contrato, uma vez que se respeitará o que se convencionou no princípio. Diz a lei do contrato, e seguimos esta opinião, que não vale, e Celso entende não ser certo, se houver convencionado que não se respondesse por dolo, uma vez que isto é contrário ao juízo de boa-fé. Mas sobre os acidentes com animais e as mortes que ocorrem sem culpa, sobre as fugas dos escravos, que não devem estar custodiados, sobre os furtos, tumultos, incêndios, enchentes e arroubada de ladrões não se responde por nada"]. Cf. MICHEL, Jacques. op. cit., p. 62 (= n. 81), realiza duas inserções neste parágrafo. A primeira "sed haec ita nisi si quid nominatim convenit (vel plus vel minus) in singulis contractibus" $\mathrm{e}$, a segunda "Nam hoc servabitur quod initio convenit (legen enim contractus dedit), excepto eo quod Celsius putat non valere si convenerit ne dolus praestetur".

148 Cf. PASTORI, Franco. Il commodato... cit., p. 303-305. Quanto ao texto de Ulp. 29 ad ed., D. 50, 17, 23, a probabilidade é que se trate de uma elaboração escolástica do século IV d. C., sobre a qual se sobrepôs a interferência dos compiladores. São duas as alterações que se apresentam no texto: a culpa, critério típico da mentalidade pós-clássica (considera-se inclusive o "dolus" como inserção pós-clássica neste trecho), e a diligentia, entendida como diligentia exactissima, a qual veio a ser inserida por obra dos compiladores, com o objetivo de representar uma responsabilidade mais grave do que aquela que alguns devedores têm em suas relações jurídicas. Além disso, outras incongruências podem ser apontadas no texto, desde aspectos de construção gramatical até a inclusão entre os contratos de relação, como a "datio dotis" e o condomínio, que não eram pelos clássicos considerados como tais, sendo até proposto que se substitua o nome dos contratos pelas ações que tutelam estas relações, retirando o modo um tanto quanto insólito de se referir a estes, como "venditum, pignori acceptum, lacatum". A frase "item dotis datio, tutelae, negotia gesta: in his quidem et diligentiam" seria uma interpolação, sendo, por outro lado, impossível se referir à diligentia como diligentia exactissima da compilação em relação a todos os contratos citados. É evidente que o texto deriva do período pós-clássico, mesmo que os compiladores o tenham alterado novamente, como fizerem com todo o livro $28^{\circ}$ de Ulpiano, de onde o excerto foi extraído. O que seria improvável é a inserção pelos juristas pós-clássicos da expressão "in his quidem et diligentiam”, já que estes, após terem introduzido a figura da culpa, não falariam ainda da diligentia, pois para eles tratar-se-iam de sinônimos, seja gramaticalmente, pois existe um contraste com a construção do texto, o que releva por si uma alteração posterior, seja qualitativamente. Por outro lado, os compiladores usam o termo diligentia formalmente como concepção pós-clássica, somente mudando a forma de entender esta figura. 
Por fim, lembra-se de Ulp. 28 ad ed., D. 13, 6, 5, 2-3, ${ }^{149}$ onde a inspiração da mensagem ideológica da Collatio legum Mosaicarum et Romanorum, aparece pela apresentação conjunta do dolus, da culpa e da diligentia. ${ }^{150}$

Neste contexto, o Direito pós-clássico não deve ser visto como contraposição ao clássico, mas como um desenvolvimento histórico e contínuo deste. ${ }^{151}$

O Direito pós-clássico ocupa uma posição intermediária, buscando conciliar o direito clássico, fundado na custodia de Gai. 3, 206, com a tendência cada vez mais acentuada de fundar a responsabilidade do comodatário na culpa, especialmente na exactissima diligentia de Gai. 2 aureor., D. 44, 7, 1, 4. ${ }^{152}$

Por isso, nos textos pós-clássicos que estão fora da compilação justinianéia, nota-se a "coesistenza della responsabilità per 'custodia' con la responsabilità per 'diligentia' o per colpa, figure nuove aggiunte alla prima". [= "coexistência da responsabilidade por custódia com a responsabilidade por diligência ou por culpa, figuras novas acrescidas à primeira"]. ${ }^{153}$

E os textos que constatam esta coexistência de critério são justamente PS. 2, 4, 3, que atribui ao comodatário a responsabilidade por custodia e por diligentia, e Modest., Coll. 10, 2, 1 e 4, onde somente se prevê uma idéia de dolus e de culpa. Este último explica-se pela particularidade da hipótese, isto é, de ser um comodato realizado no interesse de ambas as partes, como narrado, a contrario sensu, por Ulp. 28 ad ed., D. 13,

\footnotetext{
${ }_{149}$ Ulp. 28 ad ed., D. 13, 6, 5, 2: "Nunc videndum est, quid veniat in commodati actione, utrum dolus an et culpa an vero et omne periculum. et quindem in contractibus interdum dolum solum, interdum et culpam praestamus: dolum in deposito: nam quia nulla utilitas eius versatur apud quem deponitur, merito dolus praestatur solus: nisi forte er merces accessit (tunc enim, ut est et constitutum, etiam culpa exhibetur) aut si hoc ab initio convenit, ut et culpam et periculum praestet is penes quem deponitur. sed ubi utriusque utilitas vertitur, ut in empto, ut in locato, ut in dote, ut in pignore, ut in societate, et dolus et culpa praestatur". [= "Vejamos agora se a ação de comodato se refere ao dolo, à culpa ou inclusive a todo o risco. Certamente, às vezes, nos contratos respondemos apenas pelo dolo, outras vezes também pela culpa; pelo dolo no depósito, uma vez que não há utilidade para o depositário, respondendo somente por dolo, a não ser que se arbitre algum aluguel (porque, neste caso, como se estabelece, responde-se também pela culpa), ou se convenciono desde o primeiro momento que o depositário responda pela culpa e pelo risco; mas onde existe uma utilidade para as partes, como na compra, no arrendamento, no dote, no penhor, na sociedade, responde-se não somente pelo dolo, como também pela culpa"].

150 PASTORI, Franco. Il commodato... cit., p. 305.

151 Cf. Id. Ibid., p. 305.

152 Cf. Id. Ibid., p. 305.

${ }^{153}$ Cf. Id. Ibid., p. 306.
} 
6, 5, 10, ${ }^{154}$ enquanto a custodia vem acordada em Modest., Coll. 10, 2, 6, pela legitimação da actio furti ter sido dada ao comodatário. ${ }^{155}$

Entretanto, mesmo se referindo ao direito pós-clássico, Franco Pastori ${ }^{156}$ acredita que PS. 2, 4, 3, e Modest., Coll. 10, 2, 1 e 4, pertencem a dois momentos diversos deste.

Primeiramente, PS. 2, 4, 3, pensa na custodia unida à diligentia, e, posteriormente, enquanto Modest., Coll. 10, 2, 1 e 4, omitem a custodia, firmando a culpa como parâmetro de responsabilidade, Modest., Coll. 10, 2, 6, retoma a custodia, mas apenas no sentido atécnico de não ser mais nada que de uma atividade de custodiar ligada diretamente à diligentia. ${ }^{157}$

Portanto, no período pós-clássico, quanto à responsabilidade do comodatário coexistiriam os critérios do dolus, da culpa - ou da diligentia -, e da "custodia". Esta última, ainda deteria o sentido técnico de responsabilidade objetiva, como em PS. 2, 4, 3, mas, por outro lado, já também seria pressuposta em seu sentido atécnico, pelo contexto apresentado por Modest., Coll. 10, 2, 1, 4, e 6, mas sem o prejuízo de sua acepção clássica de Gai. 3, 206. ${ }^{158}$

3. 2. 3. A possibilidade da "custodia" ter sobrevivido como critério de responsabilidade do comodatário no período justinianeu

A idéia de culpa como base para um critério de responsabilidade é indiscutível. ${ }^{159}$

\footnotetext{
154 "Interdum plane dolum solum in re commodata qui rogavit praestabit, ut puta si quis ita convenit: vel si sua dumtaxat causa commodavit, sponsae forte suae vel uxori, quo honestius culta ad se deduceretur, vel si quis ludos edens praetor scaenicis commodavit, vel ipsi praetori quis ultro commodavit". [= "Porém, quanto à coisa entregue em comodato, o comodatário responderá, às vezes, somente por dolo. Como, por exemplo, se alguém assim convencionou (ou se o comodante em interesse próprio desejou) que sua esposa ou prometida se apresentasse mais decentemente trajada; ou se o pretor que dava uma representação teatral (em razão da eleição) entregou em comodato alguma coisa aos comerciantes, ou se alguém a desejou dar comodato ao mesmo pretor"'].

SOLAZZI, Siro. Recensão... cit., p. 263-264 acredita que desde o tempo de Modestino o princípio da graduação da responsabilidade segundo a utilitas contrahentium tinha si firmado. A regra sempre foi clara, sendo que, de costume, o benefício é apenas do comodatário e excepcionalmente do comodante. Além disso, acredita-se que pelo texto da Modest., Coll. 10, 2, 1, 4 e 6, não é possível encontrar um diálogo entre custodia e culpa, constituindo esta uma incerteza histórica.

155 Cf. PASTORI, Franco. Il commodato... cit., p. 306.

156 Id. Ibid., p. 306.

157 Cf. Id. Ibid., p. 306-307.

158 Cf. item 3.2. 1., nota 117, supra. Quanto à utilização da custodia no sentido atécnico, já ficou comprovado que em Gai. 3, 107 e 207, o depositário deve arcar com uma obrigação de custodiar, mas não por uma responsabilidade objetiva. Mas, quanto ao uso da palavra dentro do âmbito da responsabilidade do comodatário, parece que esta foi, pela primeira vez, pressuposta no sentido atécnico na Collatio Legum Mosaicarum et Romanorum. Ainda se deve observar que, pela lógica, o sentido técnico de custodia decorre do atécnico, uma vez que responder objetivamente é mais restrito do a mera obrigação de custodiar a coisa alheia.

159 Cf. ARANGIO-RUIZ, Vincenzo. Istituzioni... cit., p. 385. Esta idéia da culpa é alcançada pelo mesmo duplo
} 
O caso mais antigo de responsabilidade por culpa no campo contratual permanece com a actio rei uxoriae, ou seja, no caso do marido na restituição do dote, sendo que todo o desenvolvimento posterior do tema é, em grande parte, devida à escola pós-clássica, uma vez que os compiladores de Justiniano mais se contiveram do que prosseguiram em seu crescimento.

Assim, não há como negar, para Vincenzo Arangio-Ruiz, ${ }^{160}$ que o termo culpa foi o mais interpolado nos Digesta, por obra, naturalmente, pré-justinianéia, isto é, tais interpolações não conseguiram ser nem alteradas pelos compiladores, por mais que esses quisessem, pois os textos já teriam chegado a eles com as modificações.

O próprio sentido do termo culpa variaria, pois, no uso literário e no contexto da responsabilidade aquiliana, o vocábulo se refere a um simples nexo causal, enquanto que na matéria contratual, o "prevedibile non previsto" [= "o previsível não previsto"], a "culpa" como hoje se compreendem, somente aparece por obra dos juristas pós-clássicos.

Desta forma, o direito justinianeu mais impediria a construção da responsabilidade sobre o critério da culpa do que a favoreceria, pois estavam os juristas com maior vontade de manter as inúmeras soluções do direito clássico. ${ }^{161}$

Tornar-se-iam os compiladores justinianeus, desta forma, extremamente severos ao manterem a responsabilidade por custodia, apenas a mudando de nome para diligentia custodiendae rei, que, no sistema da compilação, sempre funciona como algo a mais do que a mera diligentia. ${ }^{162}$

procedimento que se observa nas figuras dos quase-delitos justinianeus, ou seja, restringe-se, sem extinguir, a responsabilidade dos intendentes de um navio, do comodatário, do conductor operis faciendi, aos limites do "prevedibile non previsto", e se alarga a responsabilidade do mandatário, do tutor, do sócio e do fiduciário até incluir a negligência e a imprudência. A culpa não passa da previsão de um evento para o qual o ser humano fecha os olhos, como se este fosse impossível.

Por outro lado, PASTORI, Franco. Comodato... cit., p. 690, observa que ao fim do período clássico a diligentia se consubstancia em uma figura bem definida, e este critério empírico de valorização firma o conceito dogmático e técnico da responsabilidade por diligentia, paralela à responsabilidade por culpa, na qual se compreende a neglegentia, segundo PS. 2, 4, 3.

160 ARANGIO-RUIZ, Vincenzo. Istituzioni... cit., p. 385. Somente pela possível inserção de inúmeras interpolações nos Digesta, a questão da responsabilidade contratual fica até os dias atuais aberta, configurando um amplo campo de exploração científica.

161 Cf. ARANGIO-RUIZ, Vincenzo. Istituzioni... cit., p. 385.

162 Cf. Id. Ibid., p. 385. O que mais existiria seria um medo em se falar de custodia, ou de responsabilidade objetiva, no período justinianeu, principalmente no campo contratual. Para Vincenzo Arangio-Ruiz este medo teria se traduzido em uma mera mudança terminológica - de custodia para diligentia custodiendae rei -, mas sem alterar, substancialmente, o critério de responsabilidade aplicado. No mesmo sentido, embora acredite que diligentia custodiandae rei designe uma responsabilidade subjetiva, PASTORI, Franco. Il commodato... cit., p. 254-256, afirma que dentro da evolução da responsabilidade do comodatário, a aproximação da custodia do período clássico à responsabilidade por diligentia no direito pós-clássico transformaria a primeira em diligentia exactissima in custodiendo, na fase justinianéia. Entretanto, mesmo com a influência da custodia na construção desta estranha figura justinianéia, Franco Pastori não deixa de enxergar em Gai. 2 aureor., D. $44,7,1,4$, uma responsabilidade de natureza subjetiva que exige do devedor uma medida muito alta da diligentia. Também se deve lembrar que o auge da jurisprudência romana ocorreu no período clássico, não 
Assim, os devedores que respondiam no período clássico por custodia passam, no período justinianeu, a responder por diligentia custodiendae rei, e os que respondiam apenas por dolus, e viram sua responsabilidade estendida à culpa, respondem por "diligentia quam in suis rebus socius adhibet" [= "diligência que (o sócio) se tem com as próprias coisas"]. ${ }^{163}$

Em sentido semelhante, Franco Pastori ${ }^{164}$ entende que o comodatário, na fase justinianéia, apresenta uma responsabilidade fundada na diligentia, mas não uma normal responsabilidade por diligentia, isto é, a diligência do bom pai de família, mas uma forma agravada de diligência, designada diligentia exactissima in custodiendo ou "diligentia diligentissimi patris familias", conforme, respectivamente, Gai. 2 aureor., D. 44, 7, 1, 4, e Gai. 9 ad ed. provinc., D. 13, 6, 18 pr. ${ }^{165}$

Se, por um lado, Franco Pastori ${ }^{166}$ considera que esta "estranha” figura de responsabilidade está entre os limites subjetivos da diligência, é também verdade que, por outro lado, "in pratica esse non divergono gran che dalla responsabilità per 'custodia' classica, data la difficoltà del comodatario di fornire la prova liberatoria" [= "na prática, isto não diverge muito da responsabilidade por custódia clássica, em razão da dificuldade do comodatário de fornecer a prova liberatória"].

sendo, assim, nada estranho o desejo de importar deste critérios de responsabilidade.

163 Cf. ARANGIO-RUIZ, Vincenzo. Istituzioni di diritto romano. 14. ed. Napoli: Jovene, 2006. p. 385.

164 PASTORI, Franco. Il contratto... cit., p. 94.

165 Cf. a exegese de Gai. 2 aureor., D. 44, 7, 1, 4, no item 4 (Gai. 2 aureor., D. 44, 7, 1, 4 e o estranho critério da "exactissima diligentia custodiendae rei"). Para SOLAZZI, Siro. Recensão... cit., p. 263, pode-se duvidar que a figura da exactissima diligentia introduziu-se no período justinianeu. De fato, tratar da figura da diligentia exactissima não é inventá-la, sendo possível que sua introdução ter ocorrido em um período anterior ao direito justinianeu. Esta é uma possível indagação que não pode ser esquecida.

166 PASTORI, Franco. Il contratto... cit., p. 94-96. A dificuldade de prova também dificulta a possibilidade do comodatário vir a se livrar da responsabilidade por casus minores, alegando ter a máxima diligência requerida e resolvendo-se o caso concreto por meio de uma presunção de culpa. Assim, "si deve concludere che anche nell'ottica delle concepzioni subiettive, il comodatario continua a rispondere, praticamente, per una responsabilità aggravata".

Quanto à responsabilidade do comodatário por casus, cf. ARANGIO-RUIZ, Vincenzo. Istituzioni... cit., p. 386387 , segundo o qual a responsabilidade por casus fortuitus ou vis maior, onde a coisa é perdida por causa natural ou por irresistível violência de terceiro, vigendo o princípio da libertação do devedor de qualquer vínculo, deve ser preservado. Os textos insistem que tal princípio vale somente para aqueles acontecimentos em que nenhuma prudência humana pode antever ou evitar, como o terremoto e o naufrágio, consideradas "violências divinas", e em fatos humanos realizados com o emprego de irreprimível violência, como um ataque de piratas ou de saqueadores. Nos casos em que a responsabilidade era baseada na custodia estes eram os únicos casos em que o devedor não respondia. Por sua raridade, acabava-se, às vezes, por os esquecer, dizendo, por exemplo, que o comodatário assumia “omne periculum”. Mas é um erro pensar que em um ou outro caso a responsabilidade não fosse excluída nem por eventos de força maior. A palavra periculum pode ser, neste sentido, ora sinônimo de custodia, abrangendo apenas determinados casos fortuitos, ora incluindo até mesmo a força maior (esta naturalmente excluída da custodia). Obviamente, quaisquer dos critérios existentes de responsabilidade derivados do direito objetivo constituem um padrão natural, ou seja, são possíveis serem modificados pela realização de pactos entre as partes. Por estes pactos, a responsabilidade pode ser agravada ou aliviada, salvo a colocação do pactum ne dolus praestetur, vale dizer, de não responder por dolus, que não é admitido. 
Assim, Franco Pastori ${ }^{167}$ conclui que as fontes justinianéias, após haverem firmado a responsabilidade por diligentia do comodatário, esclarecem que esta encontra apenas o limite da força maior, parecendo evidente que Justiniano não pretendia se afastar do regime clássico da responsabilidade por custodia, mas apenas a reconfiguraria no contexto de sua política legislativa, que se baseia na responsabilidade subjetiva. ${ }^{168}$

A contraposição doutrinária que sempre caracterizou o comodato, entre teoria que entende a responsabilidade do comodatário como objetiva e a que, ao contrário, entende-a entre os limites subjetivos, é compreensível ao se considerar o regime jurídico do comodato e o significado da tradição romanística na responsabilidade contratual. ${ }^{169}$

Da mesma forma, para Franco Pastori, ${ }^{170}$ no caso de somente o comodatário auferir vantagens, ou seja, do contrato somente ser útil a ele, além de ter de se abster do dolus e da culpa - "concepção negativa" - ele, ao custodiar a coisa deve ter uma diligência especial - "concepção positiva”, de agir. Mas não a diligência que ele de costume presta em suas coisas, mas aquela que a pessoa mais escrupulosa - vir diligentissimus - tem com seus próprios assuntos.

167 PASTORI, Franco. Il contratto di comodato. Bologna: Cisalpino, 1997. p. 94.

168 Id. Ibid., p. 93-95. Na mesma direção, Ulp. 28 ad ed., D. 13, 6, 5, 3, pronuncia-se, após ter afirmado, via a autoridade de Quintus Mucius Scaevola [ = "Quinto Múcio Sévola], que o comodatário responde por seu comportamento negligente - "et culpam praestandam et diligentiam" - e diz em seguida que a responsabilidade do comodatário encontra o limite na força maior, em Ulp. 28 ad ed., D. 13, 6, 5, 4 "Quod vero senectute contigit vel morbo, vel vi lastronum ereptum est [...]" [= "Não deve ser imputado ao comodatário os acontecimentos que ocorrem por velhice ou por doença, ou mesmo quando a coisa é arrebatada por força de ladrões (...)"], como também "[...] incendio vel ruina aliquid contigit vel aliquid damnum fatale [...]”, [= “(...) por incêndio, por ruína ou por qualquer outro dano fatal (...)”]. Esta idéia é óbvia dentro do contexto da responsabilidade subjetiva e justifica a mensagem do período justinianeu de se reafirmar a responsabilidade agravada do direito clássico, somente limitada à força maior. Por outro lado, isto levaria a concluir que o direito moderno teria recepcionado a tendência da responsabilidade objetiva, determinada desde o direito clássico, e a da responsabilidade subjetiva, aplicada à fattispecie ou desde o final do período clássico ou, com absoluta certeza, a partir do direito pós-clássico.

169 Id. Ibid., p. 95-96. Também não se pode esquecer que no comodato confia-se a coisa a um uso alheio, que normalmente só provoca interesse em quem a recebeu. Desta constatação, decorre a necessidade de atribuir a este uma responsabilidade particularmente grave para a conservação e restituição da coisa, o que provoca uma responsabilidade do comodatário por alguns casus minores, como o furto. E esta responsabilidade é pressuposto do regime do comodato, à revelia de qual seja seu fundamento jurídico. A responsabilidade do comodatário se gradua conforme a utilitas contrahentium, narrada em Ulp 28 ad ed., D. 13, 6, 5, 2, que ao colocar o quesito "quid veniat in commodati actione", demonstra que o devedor somente responde por dolus se as vantagens do contrato são apenas do credor, como ocorre no depósito. Mas o critério do dolus e da culpa aplica-se aos contratos bilaterais, onde as vantagens são repartidas entre os contratantes, como a compra e venda, a locação, a sociedade e o mandato. A responsabilidade do comodatário somente poderia ser mais grave, já que na maior parte das vezes somente ele aufere as vantagens do contrato. Os textos passaram a falar de "culpa et diligentia", expressão que substituiu, por obra dos compiladores, a palavra "custodia”. Se as vantagens do comodato forem recíprocas, o comodatário passa a responder só por dolus. De qualquer forma, a responsabilidade do comodatário, em qualquer fase do Direito Romano, liga-se à utilitas contrahentium. E não se pode negar que o ponto de partida para a tradição da regra da utilitas contrahentium seja a doutrina de Stefano.

170 Id. Ibid., p. 96-97. 
O nome desta diligência custodia, mas não a custódia simples, no significado que esta expressão normalmente tem - sentido atécnico -, mas a "custodia diligentissima". ${ }^{171}$

Desta forma, segundo a tese de Franco Pastori, ${ }^{172}$ a jurisprudência pré-Juliana seria orientada pela concepção objetiva, onde a custodia era um conceito independente da diligentia, e comportava a responsabilidade por furto, assim como, muito provavelmente, a deterioração cometida sem violência. $O$ fundamento desta responsabilidade não derivava da diligência, mas sim da confiança conferida devedor pela entrega da coisa.

Em seguida, teria despontado uma corrente exponencial, cujo maior representante foi Juliano, pela qual a custodia foi inserida no âmbito da diligentia, perdendo sua característica de responsabilidade objetiva, e se tornando sinônimo de culpa, salvo alguns casos em que a responsabilidade do devedor fosse agravada, ou limitada ao furto. ${ }^{173}$

Nas fontes justinianéias existe uma divergência sobre os critérios sob os quais a responsabilidade do comodatário vem considerada e fundada, logo, elas apresentam conhecidas "anomalie" [= "anomalias"] sobre estes, pois, de um lado, existem textos que mencionam a custodia, mas, por outro lado, existem textos, de fato, mais numerosos, que falam de culpa et diligentia. ${ }^{174}$

A deformidade está justamente em reconhecer textos que atuam no âmbito dos mais diversos critérios de responsabilidade, a saber, a custodia, a diligentia, a culpa, e, algumas vezes, reconhece-se até o dolus. ${ }^{175}$

A responsabilidade por dolus já era conferida nos períodos clássico e pósclássico ao comodatário quando o comodato conferia vantagens não apenas para ele, segunda

171 PASTORI, Franco. Il contratto di comodato. Bologna: Cisalpino, 1997. p. 97. Na realidade, a doutrina de Stefano, esboçada em Ulp. 28 ad ed., D. 13, 6, 5, entende a responsabilidade do comodatário entre os limites subjetivos, exigindo dele um certo zelo na conservação da coisa, que será mais ou menos intenso em razão da regra da utilitas contrahentium, isto é, o contrato ter sido concluído no interesse exclusivo de uma das partes, ou de ambas. Assim, a custodia está inserida entre os limites da culpa - "culpam sive custodiam" -, e como esta apresenta, no direito justinianeu graduações, aquela também terá. Na prática, como é fácil de notar, devido à dificuldade que apresenta o comodatário de realizar a prova liberatória, ele passa a ser responsável mesmo quando apresentou o máximo de diligência, operando-se uma presunção de culpa. Cf. item 1 (Apresentação do Problema: a "Custodia" no Direito Romano) sobre os sentidos do termo custodia.

172 Id. Ibid., p. 101-108.

173 Cf. Id. Ibid., p. 101-108. Fica claro que para este autor, embora o estado atual das pesquisas estabelece o campo de aplicação da responsabilidade por custodia técnica ao direito clássico, opondo a este o período justinianeu, baseada na culpa, a qual apenas teria recepcionado a custodia em sentido atécnico, ainda na compilação justinianéia existiriam traços vivos da custodia técnica.

174 PASTORI, Franco. Il commodato... cit., p. 253.

175 Id. Ibid., p. 253-254. A tese de Franco Pastori traçada em sua obra inaugural de 1954 (Il commodato nel diritto romano - Con contributi allo studio della responsabilità contrattuale) em nada se alterou até seu último parecer sobre o tema em 1997 (Il contratto di comodato), no qual, embora o foco seja o direito italiano vigente, traz uma grande evolução histórica desde o período romano. Por outro lado, deve-se perceber que o autor denomina, como membro da segunda geração exegética sobre o comodato, de "anomalie" os critérios de responsabilidade do comodatário que seriam encontradas no Corpus Iuris Civilis, o que pode ser encarado como uma possibilidade concreta da operação da custodia como critério autônomo de responsabilidade no período justinianeu. 
era normal nesta relação - Ulp. 28 ad ed., D. 13, 6, 5, 3-, mas repartia-se entre as partes - Ulp. 28 ad ed., D. 13, 6, 5, 10, e Modest., Coll. 10, 2, 1 -, representando uma simples atenuação da responsabilidade por custodia já introduzida na fase clássica em alguns casos, como em Ulp. 28 ad ed., D. 13, 6, 5, 6, e Gai. 7 ad ed.provinc., D. 6, 1, 36, $1 .{ }^{176}$

A divergência de critérios, que se aproximam no período justinianeu, no comodato denotam uma estratificação de concepções jurídicas derivadas de uma evolução histórica, e bem compreendidas em uma obra que expõe o direito do tempo de Justiniano, utilizando critérios que os antigos jurisconsultos analisaram em diversos períodos da já longe fase clássica.

Estes inúmeros critérios vão tentar ser harmonizados, segundo Franco Pastori, ${ }^{177}$ por parte dos compiladores com os ensinamentos da escola pós-clássica. Ademais, por meio da análise desta estratificação ou "anomalia" seria possível construir o processo histórico da responsabilidade do comodatário, separando a superestrutura pósclássica do pensamento clássico.

Em alguns textos, vem mencionada a responsabilidade por custodia isoladamente, principalmente em Inst. 4, 1, 16, Ulp. 28 ad ed., D. 13, 6, 5, 6, e Ulp. 28 ad ed., D. $13,6,5,14 .{ }^{178}$

Além deste primeiro grupo de fragmentos, o segundo grupo reúne os fragmentos que aproximam a responsabilidade por "custodia" da "diligentia" ou da "culpa" e do dolus.

Assim, Ulp. 28 ad ed., D. 13, 6, 5, 15, contrapõe em seu fim, a custodia como típica figura de responsabilidade ao dolus, à culpa e à diligência, o que permitiria sustentar que custodia detém, aqui, um significado técnico, um critério de responsabilidade autônomo frente aos demais. Não houve alternativa do que retomar a expressão "custodiam praestare" das Gai Institutiones.

O mesmo ocorre em Ulp. 28 ad ed., D. 13, 6, 5, 5, onde a custodia é colocada lado a lado com a diligentia, adicionando-a, "etiam diligentem", à primeira. ${ }^{179}$

176 PASTORI, Franco. Il commodato... cit., p. 254.

177 Id. Ibid., p. 254. A idéia de Franco Pastori é simples e fundada na divisão dos fragmentos das fontes romanas em cinco grupos, conforme os critérios de responsabilidade se apresentam. No primeiro grupo de fragmentos, a custodia vem citada como responsabilidade única do comodatário, enquanto, no segundo grupo, ela mantém seu sentido técnico, embora não seja mais o único critério de responsabilidade. Em um terceiro grupo, a responsabilidade do comodatário vem inclusa dentro do âmbito da diligentia. Por fim, no quarto grupo, trata-se da exactissima diligentia custodiendae rei e, no quinto grupo, da culpa et diligentia. SOLAZZI, Siro. Recensão... cit. , p. 262, reconhece um exame crítico-exegético nesta forma de raciocínio e divisão.

178 PASTORI, Franco. Il commodato... cit., p. 254-256.

179 PASTORI, Franco. Il commodato in diritto romano. 3. ed. Milano: Cisalpino, 1997. p. 256-257. Também neste segundo grupo se insere Ulp. 28 ad ed., D. 13, 6, 5, 9, hipótese escolástica que propõe uma extensão da responsabilidade do comodatário, seguindo a regra que o acessório segue o principal, de conservação da coisa emprestada também sobre seus acessórios. Assim o texto é explícito a afirmar que a diligentia também deve 
A terceira combinação de critérios ocorre em Paul. 5 ad. Sab., D. 18, 6, 3, onde a responsabilidade por custódia aparece incluída dentro do âmbito da diligentia. ${ }^{180}$

Neste texto, o vendedor é obrigado a responsabilidade por custodia assim como o comodatário, mas obviamente aqui o termo custodia é usado em sentido atécnico, e, assim, equivale à responsabilidade por diligentia. Ao falar de uma diligência extremamente escrupulosa - diligentia quam suis -, traz uma figura tipicamente justinianéia.

Até este fragmento ser analisado, poderia se dizer que a custodia era entendida como figura autônoma de responsabilidade, mas Paulo a faz perder a substância objetiva existente desde os textos de Gaio. ${ }^{181}$

Um quarto grupo de fragmentos fala da exacta ou exactissima diligentia custodiendae rei, como em Inst. 3, 14, 2, e Gai. 2 aur., D. 44, 7, 1, 4, onde desaparece qualquer menção à custodia em sentido técnico. ${ }^{182}$

Nestes textos a custodia aparece em seu sentido atécnico como ato de custodiar a coisa emprestada e suas relativas obrigações.

Segundo estes, no cumprimento da obrigação de custodiar a coisa emprestada, o comodatário deve empregar uma particular diligentia, isto é, uma diligentia exacta ou exactissima.

Logo, pela própria construção gramatical, a diligentia é a responsabilidade atribuída ao comodatário, e custodia rei, como atributo no genitivo, é mera referência à obrigação baseada na conservação da coisa.

Por fim, no quinto agrupamento de critérios, a custodia não vem mencionada, nem em sentido atécnico, como anteriormente no quarto agrupamento, mas somente o dolus, a culpa e a diligentia são indicadas como critérios de responsabilidade do comodatário. Estes são, exatamente, Ulp. 28 ad ed., D. 13, 6, 5, 3, Ulp. 29 ad. Sab., D. 50, 17, 23, e Gai. 9 ad ed. provinc., D. 13, 6, 18 pr. Enquanto os dois primeiros falam apenas de "diligentia", o último fala de "dilidentia diligentissimi patrisfamilias". ${ }^{183}$

ser prestada aos acessórios, como no caso de um cavalo acompanhado de um pullus, isto é, a responsabilidade por custodia também se estende a este. No texto fala-se ainda de "autem diligentia", assim, uma "diligentia" como figura somada a antiga responsabilidade por custodia, a qual concerne à resposta dos antigos. Assim, os compiladores, sobre a norma de responsabilidade por custodia dos acessórios dos antigos, acrescentaram a diligentia. Recorda-se, por fim, Ulp. 38 ad ed., D. 13, 7, 13, 1, onde a responsabilidade do credor pignoratício é conduzida ao mesmo regime da responsabilidade do comodatário e, por isso, o texto introduz a figura do dolus e da culpa ao lado da custodia. E, por esta estar ao lado de outras típicas figuras de responsabilidade, detém a custodia sentido técnico de responsabilidade objetiva.

180 Cf. Id. Ibid., p. 258. Cf. texto de Paul. 5 ad. Sab., D. 18, 6, 3 na nota 141, supra.

181 Id. Ibid., p. 258.

182 Cf. Id. Ibid., p. 258. Cf. item 4 (Gai. 2 aureor., D. 44, 7, 1, 4 e o estranho critério da "exactissima diligentia custodiendae rei").

183 PASTORI, Franco. Il commodato in diritto romano. 3. ed. Milano: Cisalpino, 1997. p. 259-260. Aqui também é curiosa a contraposição entre culpa e diligentia entendidas nestes textos como figuras autônomas e distintas de responsabilidade, mas inexplicáveis no plano lógico, pois a primeira não consiste em nada mais que uma 
Estes textos demonstram as mensagens dos compiladores de omitir qualquer menção sobre a custodia, seja em qual sentido esta for entendida.

Assim, torna-se evidente e indubitável que nos textos do Corpus Iuris Civilis exista uma pluralidade de critérios de responsabilidade do comodatário. ${ }^{184}$

Importa, neste momento, excluindo por enquanto a gradual intensidade da diligentia nos fragmentos, perceber a divergência entre os textos que se referem à custodia tecnicamente entendida - Inst. 4, 1, 16, Ulp. 28 ad ed., D. 13, 6, 5, 6 e 14 - daqueles que fazem menção à custodia em sentido atécnico e à responsabilidade do comodatário voltada para culpa e diligentia - Paul. 5 ad. Sab., D. 18, 6, 3; Inst. 3, 14, 2; Ulp. 28 ad ed., D. 44, 7, 1, 4; Ulp. 28 ad ed., D. 13, 6, 5, 3, ${ }^{185}$ Ulp. 29 ad Sab., D. 50, 17, 23; e Gai. 9 ad ed. provinc., D. 13, 6, 18 pr.

Frente a estes dois conjuntos de textos, existe um terceiro intermediário que envolve a custodia em sentido técnico, enquanto figura autônoma de responsabilidade, mas aproximada de outros critérios de responsabilidade, a saber, a diligentia - Ulp. 28 ad ed., D. 13, 6, 5, 15; Ulp. 28 ad ed., D. 13, 6, 5, 5; Ulp 28 ad ed., 13, 6, 5, 9 e Ulp. 38 ad ed., D. 13, 7, 13, 1-, o que distorce a concepção clássica. ${ }^{186}$

Entretanto, todas as divergências destes conjuntos de textos para Franco Pastori, ${ }^{187}$ à luz do espírito justinianeu, atenuam-se notavelmente, e os textos consentem em uma interpretação unívoca, conforme o espírito deste período.

violação da segunda, ou seja culpa nada mais seria que neglegentia. Culpa e diligentia configuram o mesmo tipo de responsabilidade, o que também ocorre em outros fragmentos como Gai. 2 rerum cottidianar. sive aureor., D. 17, 2, 62, Gai. 10 ad ed. provinc., D. 19, 2, 2 pr., e Proc. 6 epist., D. 18, 1, 68 pr.

${ }^{184}$ Cf. Id. Ibid., p. 260.

${ }^{185} \mathrm{Na}$ realidade, incluir Ulp. 28 ad ed., D. 13, 6, 5, 3, como um exemplo da responsabilidade subjetiva do comodatário não configura a melhor alternativa. HAYMANN, Franz. op. cit., p. 188-189, defende que este texto apresenta tanto a idéia de culpa, no início do texto ("Commodatum - diligentiam"), que teria sido objeto de interpolação, por decorrência inclusive de uma duplicidade de sentidos do verbo "praestare" na frase "praestandam culpam et diligentiam", mas, por outro lado, manteve o critério da custodia, por meio da possibilidade de se suportar "omne periculum" [= "qualquer risco"]. Em sentido oposto, defendendo a responsabilidade subjetiva em todo o texto, cf. KRÜCKMANN, Paul. op. cit., p. 16-18, e TARDIVO, CarloMaria. op. cit., p. 8-9.

Ulp. 28 ad ed., D. 13, 6, 5, 3: "Commodatum autem plerumque solam utilitatem continet eius cui commodatur, et ideo verior est Quinti Mucii sententia existimantis et culpam prestandam et diligentiam et, si forte res aestimata data sit, omne periculum praestandum ab eo, qui aestimationem se praestaturum recepit". [= "Em regra, é comum que no comodato exista utilidade (apenas) para o comodatário, e, por isso, é mais exata a opinião de Quinto Múcio (Sévola), pela qual este (o comodatário) responde tanto por culpa, como por diligência. Além disso, se por acaso a coisa emprestada for estimada, aquele que aceitou suportar a avaliação responde (também) por todo o risco."].

186 Cf. PASTORI, Franco. Il commodato in diritto romano. 3. ed. Milano: Cisalpino, 1997. p. 260. Também com estas figuras de responsabilidade - custodia, culpa, e diligentia - aparece o dolus, ora com as três - Ulp. 28 ad ed., D. 13, 6, 5, 15 -, só com a custodia ou a culpa - Ulp. 38 ad ed., D. 13, 7, 13, 1 - ou só com a culpa e diligentia - e Ulp. 29 ad Sab., D. 50, 17, 23.

187 Id. Ibid., p. 260-261. 
As divergências apresentam para este último relevante interesse somente do ponto de vista histórico, para identificar as etapas evolutivas da responsabilidade do comodatário, fases que começam no direito clássico e vão até o sistema justinianeu, sendo possível identificar neste uma tendência definida, ao menos em grandes linhas, que domina todo o sistema contratual e, principalmente, o comodato. ${ }^{188}$

Mas o próprio Franco Pastori, ${ }^{189}$ mesmo aceitando a culpa como "tendenza definita" [= "tendência definitiva"] no direito justinianeu, o chama atenção sobre os compiladores e os critérios de responsabilidade que estes operavam, não nega que se deva ter em mente que "nella pratica non di raro il regime positivo diverge da tale tendenza" [= "na prática não raramente o regime positivo diverge desta tendência"].

Franco Pastori ${ }^{190}$ cita como fruto desta tendência os casos em que a responsabilidade por custodia é apresentada em sentido técnico, como qualitativamente disforme da diligentia e da culpa, que comportavam uma valorização subjetiva da responsabilidade, da qual a custodia prescinde, que não é a hipótese de Inst. 4, 1, 16, que reproduz exatamente Gai. 3, 206, e apresenta, então, pouco relevo na disciplina positiva, já que é mera lembrança de um regime já ultrapassado.

Além deste, os outros dois textos em que esta figura aparece com tamanha autonomia estão ambos em Ulp. 28 ad ed., D. 13, 6, 5. A política dos legisladores aparece

188 PASTORI, Franco. Il commodato in diritto romano. 3. ed. Milano: Cisalpino, 1997. p. 261, 269-271. A tendência teórica de responsabilidade subjetiva do comodatário seria concretizada plenamente, isto é, sem qualquer menção à expressão “custodiam praestare”, no direito bizantino. Segundo SANTARELLI, Umberto. op. cit., p. 34-37, ao tratar do comodato no direito medieval, a divisão entre culpa lata, levis et levissima, embora conhecida pelos juristas da época de Justiniano, seria tipicamente medieval, pois, nesta altura, a coerência sistemática impunha à culpa que esta se estruturasse de forma plúrima, transformando também em plúrima a fattispecie típica do comodato. E para a estruturação deste conceito tríplice de culpa, os medievais utilizaram o "critério do interesse", ou "gratia", os quais já eram vistos nos textos romanos como critério de individualização do contrato de comodato frente a outros contratos, e somente em parte como forma de variação significativa de várias espécies de comodato. Assim, foi possível estruturar, a partir da gratia, três espécies de comodato: "gratia commodantis" [= "comodato de interesse exclusivo do comodante"], gratia utriusque [= "comodato no interesse de ambas as partes"] e gratia commodatarii [= "comodato de interesse exclusivo do comodatário"]. Sobre a gênese pós-clássica do "Utilitätsprinzip" [= "princípio da utilidade ou do interesse"], cf. WIEACKER, Franz. Haftungsformen des römischen Gesellschaftsrechts. Zeitschrift der Savigny-Stiftung für Rechtsgeschichte-Romanistische Abteilung, Weimar, v. 54, p. 35-79, 1934. p. 35; 41-42 $(=\S \S 2)$. Além disso, segundo BUSSI, Emilio. La formazione dei dogmi di diritto privato nel diritto comune. Contratti, successioni, diritti di famiglia. In: STUDI di diritto privato italiano e straniero diretti da Mario Rotondi. Padova: CEDAM, 1971. v. 27, p. 57-61 (= n. 85). No direito canônico, haveria uma evolução do comodato em quatro aspectos: na sua distinção com o contrato de precário; na ampliação do objeto cabível (envolvendo imóveis, móveis e semoventes); na noção de que o comodante deve esperar o uso da coisa pelo comodatário para a requerer; e na idéia que o comodatário, se o comodato fosse constituído gratia sui, respondia por culpa levissima. Sobre as diferenças e semelhanças entre o comodato no direito canônico e moderno, cf. MAIA, Paulo Carneiro. Comodato. In: Enciclopédia Saraiva do Direito. São Paulo: Saraiva, 1977. v. 16, p. 272-283.

189 PASTORI, Franco. Il commodato... cit., p. 261.

190 PASTORI, Franco. Il commodato in diritto romano. cit., p. 261. 
nestes fragmentos, onde a custodia é aproximada de figuras de natureza subjetiva e seria testemunha que a tendência teórica é unívoca. ${ }^{191}$

Assim, não se pode negar, por um lado, que Gaio somente operou com a responsabilidade por custodia, tratando a responsabilidade do comodatário dentro de um conceito desta extremamente rígido, frente ao qual era estranho qualquer investigação subjetiva, e, por outro lado, que os fragmentos de Ulpiano, contidos em D. 13, 6, 5, são extremamente instrutivos, pois a menção da custodia é fruto de tratamento diverso, mas as demais figuras colocadas perto desta não são derivadas do período clássico, pois contrastam com o "custodiam praestare" de Gaio. ${ }^{192}$

Embora não possa se negar que os textos tenham sofrido alterações anteriores a época justinianéia, ${ }^{193}$ a afirmação de que os critérios de responsabilidade

${ }_{191}$ Cf. PASTORI, Franco. Il commodato in diritto romano. 3. ed. Milano: Cisalpino, 1997. p. 261.

192 Cf. Id. Ibid., p. 262-265. Percebe-se que Ulpiano começa este conjunto de textos pelo exame da actio in factum, isto é, o meio mais adequado para se exercer a responsabilidade por custodia. Por isso, após a pergunta "quid veniat in commodati actionem", a responsabilidade do comodatário se limita ao dolus e a culpa em D. 13, 6, 5, 2, sem menção à custodia. O texto Ulp. 28 ad ed., D. 13, 6, 5, 3, propõe também um requisito para que o comodatário responda pelo periculum, o que ocorreria automaticamente se "res aestimata data sit”. Aqui vem lembrada a autoridade de Quinto Múcio Sévola e a solução é tomada por legítima, pois se o reddere não tinha por objeto a coisa emprestada mas sua aestimatio, a relação pode ser conduzida ao mútuo, onde a transferência da propriedade das coisas fungíveis justifica a responsabilidade por omne periculum. A opinião de Quinto Múcio Sévola encontra justificação histórica devido às semelhanças entre o mútuo e o comodato, e à elaboração jurisprudencial que retoma a diferença entre ambos. De qualquer forma, Ulp. 28 ad ed., D. 13, 6, 5, 4, demonstra que nunca o comodatário responde por vis maio. Mas, mesmo que Ulp. 28 ad ed., D. 13, 6, 5, 3, fale de "omne periculum" não responde o comodatário por custodia, até porquê esta detém um significado distinto de periculum.

Nos dois fragmentos seguintes - Ulp. 28 ad ed., D. 13, 6, 5, 5-6 - a custodia vem aproximada da diligentia, perdendo o significado que existia nas Gai Institutiones. A custodia, enfim, contrasta nitidamente com os pressupostos do período justinianeu. Os clássicos entendiam o "custodiam praestare" como uma figura paradigmática e, logo, desvinculada de qualquer pacto, devido à natureza de responsabilidade absoluta e normal no comodato, enquanto a realização de um pacto, em D. 13, 6, 5, 6, demonstra a excepcionalidade da custodia, que só via um acordo, produziria seus efeitos. O mesmo fenômeno ocorre em Ulp. 28 ad ed., D. $13,6,5,14$, onde a custodia cai em terreno convencional, perdendo seu efeito naturalmente vinculante. O significado do "custodiam praestare" resolve-se no fato que o comodatário deve suportar o periculum da coisa a ele confiada, mas se o periculum sem a restituição afasta o conceito de custodia, pois nesta não se responde por vis maior, a regra não se refere ao comodato no período justinianeu, pois somente excepcionalmente o comodatário responde pelo periculum, segundo Ulp. 28 ad ed., D. 13, 6, 5, 3, fattispecie esta estranha ao comodato, mas conhecida do mútuo. Os compiladores para fazer com que o comodatário responda por periculum, o chamam erroneamente de custodia.

Assim, Ulp. 28 ad ed., D. 13, 6, 5, 6 e 14, falam de custodia e, pelo menos, o primeiro fragmento, usa o termo no sentido originário. Porém, ao ser interpretado dentro do sistema do Corpus Iuris Civilis, o conceito é deformado e limitado por critérios subjetivos, perdendo a custodia sua acepção técnica original.

${ }^{193}$ Cf. PASTORI, Franco. Il commodato... cit., p. 261, 272-273. Da mesma forma, não se pode negar que foi por obra dos compiladores introduzida a figura da diligentia exactissima ou "diligentia diligentissimi patris familias", seja tanto nos Digesta como nas Iustiniani Institutiones, como formulação genérica, a qual o pensamento justinianeu entendia como critério interpretativo da responsabilidade do comodatário. Só assim se pode entender o porquê que a diligentia aparece ao lado da culpa, mas sempre entendida como diligentia exactissima ou "diligentia diligentissimi patris familias".

Assim, o esquema da responsabilidade do comodatário no direito justinianeu pode ser resumido facilmente, 
teriam se aproximado sob a forte tendência da responsabilidade subjetiva, perdendo-se assim qualquer outro critério de responsabilidade - como a custodia - não convence, uma vez que trilhado o caminho entre ponto de partida da responsabilidade do comodatário e a conclusão que esta alcançou, não se resolve o problema.

Em primeiro lugar, pois o próprio Franco Pastori ${ }^{194}$ admite que a aproximação da custodia da diligentia provocaria a fusão das figuras na expressão "diligentia exactissima in custodiendo" e/ou "diligentia diligenti custodiendo", ${ }^{195}$ enquadrando a responsabilidade do comodatário no âmbito da diligentia, mas de uma diligência extremamente rigorosa, cuja prova era muito difícil de ser realizada, que na prática se assemelhava à custodia.

Tratava-se, na prática, de uma responsabilidade não diferente da custodia, pois, o que, na realidade, houve, foi a conservação do regime clássico da responsabilidade do comodatário - responsabilidade por custodia - com a mudança do pressuposto teórico. ${ }^{196}$

Em segundo lugar, a divisão dos textos em cinco grupos não apenas evidencia que existiu a estranha figura da diligentia exactissima in custodiendo, como também demonstra que a custodia foi mantida em vários excertos como critério autônomo de responsabilidade, que vai muito além de mero interesse histórico.

Também para Pierluigi Zanninni ${ }^{197}$ a responsabilidade do comodatário, mesmo que em um diverso nível da culpa entendida como transgressão de uma regra de conduta, não seria "dissimile da quello derivante dal "praestare custodiam »" [= "diverso daquele derivado do praestare custodiam"].

para F. Pastori. Se apenas o comodatário aufere as vantagens do contrato, ele responde por diligentia exactissima; se as vantagnes são repartidas entre ele e o comodante, o primeiro responde por dolus e culpa; mas, se as vantagens são apenas do credor, o comodatário responde apenas por dolus.

Excepcionalmente, o comodatário responde por periculum, assumindo uma responsabilidade objetiva e absoluta, embora não integrando a fattispecie plenamente, como em Ulp. 28 ad ed., D. 13, 6, 5, 3. Por fim, no texto das Inst. 3, 14, 2, fala-se de "exacta diligentia", uma ocorrência anômala, já que a simples menção da diligentia já conduzia à exactissima diligentia de Gai. 2 aureor., D. 44, 7, 1, 4. A anomalia se explica com a suposição de que os compiladores das Iustiniani Institutiones e dos Digesta tenham utilizado duas redações diferentes da "Res Cottidianae". Os primeiros uma redação mais antiga, onde os critérios de responsabilidade do comodatário não tinham ainda encontrado uma segura sistematização.

194 PASTORI, Franco. Comodato... cit., p. 690. Isso explicaria o porquê de se ter continuado a se aplicar aos casos concretos, como a jurisprudência demonstra, a formula in factum, ao invés de a retirar imediatamente, uma vez que o comodato foi tutelado por uma formula in ius.

${ }^{195}$ Cf. ZANNINNI, Pierluigi. op. cit., p. 34. Aliás, estas figuras estranhas de responsabilidade, que aparecem nas fontes romanas nos períodos pós-clássico e justinianeu, podem ser encaradas como o medo de se manter a custodia como parâmetro de responsabilidade do comodatário. Porém, ocasionaram a perpetuação desta que teoricamente estava revogada.

196 Cf. PASTORI, Franco. Comodato... cit., p. 690. Segundo este último autor, nos períodos pós-clássico e justinianeu, ocorre uma fusão dos critérios da culpa e da custodia, passando a responsabilidade do comodatário a observar uma exacta ou exactissima diligentia custodiendae rei, segundo Inst. 3, 14, 2, e Gai. 2 aureor., D. 44, 7, 1, 4, o que demonstraria a interpolação deste último.

197 ZANNINNI, Pierluigi. op. cit., p. 34. 
Portanto, longe de se desejar tratar da custodia apenas no período clássico do Direito Romano, e de se firmar uma única tendência subjetiva da responsabilidade no direito justinianeu, o exame crítico-exegético das fontes romanas desmascara talvez o óbvio.

Por um lado, que a figura da diligentia exactissima in custodiendo, mesmo que o desejo fosse formá-la no critério da diligentia, não passa da figura da custodia, e, por outro lado, a presença da custodia enquanto figura autônoma de responsabilidade nas fontes não pode levar ao tortuoso raciocínio de Franco Pastori ${ }^{198}$ de que na teoria a regra é a culpa, mas na prática sempre imperou a custodia.

\section{3. Apontamentos finais sobre as vantagens de uma responsabilidade por "custodia"}

Otto Lenel ${ }^{199}$ apresenta certo cepticismo quanto à possibilidade de um julgador poder analisar uma caso concreto por meio dos ditames da boa-fé - "nach Treu und Glaube" - e se afastando, assim, do direito escrito e vigente, do próprio ius civile.

Esta preocupação transparece em sua breve análise sobre a estrutura formular do comodato: o julgamento baseado na boa-fé, por meio da actio in ius, pelo qual o iudex estaria autorizado a sair de um parâmetro estritamente objetivo, pode talvez configurar um "mau caminho" a se seguir, pois se pode deixar de aplicar o direito vigente em troca dos ditames da boa-fé.

Franz Haymann ${ }^{200}$ aponta que, embora a responsabilidade por custodia, pela literalidade de Gai. 3, 203-206, recaia somente sobre o furto, pode-se considerar que o comodatário responderá por qualquer subtração da coisa realizada por terceiro, não importando quais seriam as circunstâncias. Esta responsabilidade apresentaria uma característica especial: a capacidade de determinar com limites exatos - ou pelo menos com maior precisão - a responsabilidade do comodatário, o que talvez não possa ser atingido pelo fluido critério da culpa.

Além disso, e por conseqüência deste maior rigor na determinação da responsabilidade por custodia, Mario Talamanca ${ }^{201}$ também assinala que a ampliação do âmbito de cabimento deste critério de responsabilidade apenas se daria ao final do período clássico, e talvez justamente por um choque do critério subjetivo da culpa.

Certo, por fim, que ao se definir a custodia como um critério autônomo de responsabilidade, os seus limites podem ser facilmente traçados, podendo ser aplicada,

\footnotetext{
198 PASTORI, Franco. Il commodato... cit., p. 261-273.

199 LENEL, Otto. op. cit., p. 253 (=§ 98).

200 HAYMANN, Franz. op. cit., p. 168-169.

201 TALAMANCA, Mario. op. cit., p. 562. Embora Mario Talamanca considere a existência de um risco nesta extensão da responsabilidade por custodia a todo tipo de dano - inclusive pela exatidão de sua aplicação à fattispecie -, parece nítida a preocupação do autor em contrapor o critério não tão seguro da culpa à exatidão cabalística da custodia.
} 
com uma incrível facilidade, desde contratos mais simples até às maiores invenções do comércio:202 é "o preto no branco", ou o devedor responde em determinadas hipóteses por custodia, ou simplesmente não responde.

Resta-nos, agora, mas de igual ou maior importância, realizar as exegeses dos principais textos referentes à responsabilidade por custodia do comodatário, principalmente quanto à possibilidade desta ter ou não sobrevivido ao impacto da culpa no período justinianeu.

4. Gai. 2 aureor., D. 44, 7, 1, 4, e o estranho critério da "exactissima diligentia custodiendae rei"'203

\section{1. Exegese das Fontes Romanas}

Quanto à responsabilidade do comodatário no período justinianeu, é impossível deixar de analisar um texto atribuído a Gaio, que trata da misteriosa "exactissima diligentia custodiendae rei": 204

202 ARANGIO-RUIZ, Vincenzo. Responsabilità... cit., p. 80-82.

203 Sobre a exegese de Gai. 2 aureor, D. 44, 7, 1, 4, cf., entre outros: ARANGIO-RUIZ, Vincenzo. Responsabilità... cit., p. 62-82; CICOGNA, Giovanni. Ancora sull'uso nel comodato. In: BULLETTINO dell'Istituto di Diritto Romano. Roma: Giuffrè, 1907. v. 19, p. 235-254; FERRINI, Contardo. op. cit., p. 153-161; TARDIVO, CarloMaria. op. cit., p. 82-91; HAYMANN, Franz. op. cit., p. 202-204; HEUMANN, Hermann Gottlieb; SECKEL, Emil. op. cit., p. 112-113, 116-117; KRÜCKMANN, Paul. op. cit., p. 1-56 (= §§ 1-12); KUNKEL, Wolfgang. op. cit., p. 271-274, 286; LUZZATTO, Giuseppe Ignazio. Caso fortuito... cit., p. 111-131; MERCADO, Javier Belda. La responsabilidad del comodatario en el derecho romano. Revista Electrónica de la Facultad de Derecho de la Universidad de Granada, Granada, p. 1-23, 2007; PFLÜGER, Heinrich Hackfeld. op. cit., p. 121-138 (= § 1); POLÁCEK, Vojtech. Comodato e furto: spunti d'interpretazione dialettica. In: $L A B E O$ : Rassegna di Diritto Romano. Napoli: Jovene, 1955-. v. 19, p. 161-184; e SCHERILLO, Gaetano. Comodato. In: ENCICLOPEDIA del Diritto. Milano: Giuffrè, 1960. v. 7, p. 989-990.

KUNKEL, Wolfgang. op. cit., p. 271, já havia deixado claro ser impossível desenvolver o argumento deste texto sem que se leve em consideração outros dois - Gai. 9 ad ed. provinc., D. 13, 6, 18 pr., e Inst. 3, 14, 2 - que serão a seguir, no transcorrer na exposição, também analisados.

204 Observações quanto à tradução de Gai. 2 aureor., D. 44, 7, 1, 4: Existe claramente uma definição, na primeiras linhas do texto, de mutuário ("ille quidem qui mutuum accepit", ou seja, "aquele que certamente recebeu um mútuo") e de comodatário ("is [...] qui utendum accepit", isto é, "aquele que recebeu o uso da coisa").

Deve-se ainda observar, quanto ao texto latino, que ao se referir à responsabilidade do mutuário, enuncia-se que este responde se a coisa emprestada venha a perecer por um “casus". Uma vez que se transfere a propriedade da coisa ao mutuário - e este se torna proprietário, devendo devolver coisa do mesmo gênero, quantidade e espécie -, a ele se aplica a regra res perit domino. Assim, os prejuízos advindos à coisa emprestada tanto por caso fortuito, como por força maior, serão de sua inteira responsabilidade, e a palavra “casus" significa um conceito genérico que englobaria tanto o caso fortuito, como a força maior, e não apenas o primeiro, e, logo, sua tradução correta seria "acaso" (o mutuário responde por qualquer dano à coisa emprestada). Mas, para se referir à responsabilidade do comodatário, usou-se a expressão “maiore casu”, que não pode deter a mesma anatomia e sentido que "casus". Esta oposição entre mútuo e comodato possivelmente data do período clássico, o que demonstra que estes juristas já entenderiam a diferença entre tais eventos.

Ademais, por se tratar um critério técnico de responsabilidade, bem como constituir a questão chave do texto para a análise da responsabilidade do comodatário, prefere-se não traduzir a expressão "exactissima 
Gai. 2 aureor., D. 44, 7, 1, 4: "Et ille quidem qui mutuum accepit, si quolibet casu quod accepit amiserit, nihilo minus obligatus permanet: is vero qui utendum accepit, si maiore casu, cui humana infirmitas resistere non potest, veluti incendio ruina naufragio, rem quam accepit amiserit, securus est. alias tamen exactissimam diligentiam custodiendae rei praestare compellitur, nec sufficit ei eandem diligentiam adhibere, quam suis rebus adhibet si alius diligentior custodire poterit. sed et in maioribus casibus, si culpa eius interveniat, tenetur, veluti si quasi amicos ad cenam invitaturus argentum, quod in eam rem utendum acceperit, peregre proficiscens secum portare voluerit et id aut naufragio aut praedonum hostiumve incursu amiserit.

diligentia custodiendae rei". Trata-se da necessidade de determinar se este critério seria de responsabilidade objetiva, ou de responsabilidade subjetiva.

Por fim, cf. POLÁCEK, Vojtech. op. cit., p. 164-167, 174, sobre a tradução de "argentum". Em uma leitura rápida deste texto, percebe-se que Gaio distingue entre comodato, onde a obrigação de restituir a coisa é destacada como elemento essencial do contrato, e mútuo, onde a obrigação de restituir o empréstimo pecunia numerata não é de devolver a mesma coisa, mas sim aquela de mesmo gênero, quantidade, e qualidade. Aqui o jurista fala do "argentum", como já o tinha feito em Gai. 3, 196, como "utendum" para um fim especial e determinado, que em ambos é o empréstimo do "argentum" para realizar um banquete. É interessante e sintomático que o jurista não se refere em suas obras à definição de comodato - os juristas justinianeus a oferecem em Inst. 3, 14, 2 - e, da mesma forma, é notável que Gai. 3, 196, fale uma vez de "argentum utendum" e outra de "equus commodatus", pois se impõe a questão de se saber se esta distinção seria ou não intencional. Gaio teve a intenção, sem dúvida, de formular uma espécie particular de comodato quando se confia a um amigo dinheiro para ser usado em determinada direção, com objetivo e limites convencionalmente estabelecidos. Assim, fala-se de utendum de dinheiro, porque se tem em mente um uso especial e exclusivo, como organizar um banquete. Este problema perde relevância no comodato do cavalo, pois o uso deste objeto decorre, na maioria das vezes, da própria natureza da coisa. Além disso, Gaio distingue entre utendum e mútuo, visto que o mutuário deve devolver a quantia em dinheiro mesmo se a tivesse perdido em razão de força maior, mas quem recebe uma quantia financeira em utendum não responde por força maior, salvo se o devedor não a utilizar da forma convencionada. De qualquer forma fica claro que os compiladores utilizaram Gai. 3, 196, em Inst. 4, 1, 16. Na verdade, o substantivo "argentum" tem configurado uma verdadeira polêmica por parte dos autores quanto à tradução. Prefere-se ora "argenterie" [= "utensílios de prata"], ora "a loan of silver" [= "empréstimo de prata"] e ora "comodato di danaro ad pompam vel ad ostentationem". De qualquer forma, é aconselhável evitar a tradução literal da palavra "argentum" para "prataria", pois com absoluta certeza desejou-se criar nesta hipótese uma espécie restrita de comodato. Outro texto, que cabe aqui apontar, seria Ulp. 28 ad ed., D. 13, 6, 1, 1, onde o jurista distingue expressamente "commodatum" de "utendum", que é uma diferença do ponto de vista substancial e que diz respeito ao objeto de um ou outro contrato. O comodato era, na realidade, um verdadeiro quebra-cabeça para os juristas antigos, e ainda se lembra que estes, como Labeão, em Ulp. 28 ad ed., D. 13, 6, 1, 1, distinguiam, com exatidão e quanto à essência da coisa, entre móveis de imóveis: "commodatum" referia-se apenas às coisas móveis, enquanto "utendum" às coisas imóveis. Assim, coisas imóveis não poderiam ser entregues em comodato, mas apenas usadas. O que teria levado os juristas a inserir o "utendum" dentro da figura do "commodatum" fica ainda enigmático, e só foi explicado até hoje do ponto de vista histórico-dogmático. Mesmo os juristas posteriores não teriam se liberado plenamente desta distinção, embora particularmente Gaio tenha reconduzido ambas a uma figura comum. Somente no período justinianeu, nas Inst. 3, 14, 2, haveria esta menção expressa. De qualquer forma, fica registrada a opinião de Vojtech Polácek, embora se mantenha a tradução de "argentum" para "baixela de prata", por motivos de compreensão desta. 
E se o mutuário por qualquer acaso perder o que recebeu, não fica [por este] menos obrigado, mas certamente o comodatário fica isento de responsabilidade, se perder aquilo que recebeu por força maior, evento este que a fraqueza humana não pode resistir, como, por exemplo, no caso do incêndio, da ruína ou do naufrágio. Em outras palavras, [o comodatário] deve responder pela exactissimam diligentiam custodiendae rei, já que não basta que ele preste a mesma diligência que tem com seus próprios bens, caso possa custodiar a coisa emprestada com maior diligência. Mas, se o comodatário intervier com culpa, mesmo nas hipóteses de força maior, será responsável, como, por exemplo, se da mesma forma que convidou amigos para um jantar, recebeu para usar neste uma baixela de prata, e, querendo a levar em viagem ao exterior, esta se tivesse perdido em um naufrágio, em um assalto de bandidos ou em um ataque de inimigos.

\section{Para Giuseppe Ignazio Luzzatto, ${ }^{205}$ a exactissima diligentia custodiendae} rei é considerada uma síntese da passagem da responsabilidade objetiva clássica do comodatário para a subjetiva. Os autores são concordes que este texto deve ser interpretado com outro de Gaio: ${ }^{206}$

Inst. 3, 14, 2: "Item is cui res aliqua utenda datur, id est commodatur, re obligatur et tenetur commodati actione. sed is ab eo qui mutuum accepit longe distat: namque non ita res datur, ut eius fiat, et ob id de ea re ipsa restituenda tenetur. et is quidem qui mutuum accepit, si quolibet fortuito casu quod accepit amiserit, veluti incendio ruina naufragio aut latronum hostiumve incursu, nihilo minus obligatus permanet. at is qui utendum accepit sane quidem exactam diligentiam custodiendae rei praestare iubetur nec sufficit ei tantam diligentiam adhibuisse, quantam suis rebus

205 LUZZATTO, Giuseppe Ignazio. Caso fortuito... cit., p. 112. Segundo Giuseppe Ignazio Luzzatto, pode-se tranquilamente afirmar que Ulp. 28 ad ed., D. 13, 6, 5, 5-15, correspondem ao tratamento original dado por Ulpiano, enquanto que Ulp. 28 ad ed., D. 13, 6, 5, 2-4, foram objeto de interpolações. Assim, o regime da responsabilidade do comodatário, no período justinianeu, encontrar-se-ia, além de em Gai. 2 aureor., D. 44, 7, 1, 4, nos excertos alterados de Ulpiano. Para Giuseppe Ignazio Luzzatto, seria a prova da responsabilidade subjetiva do comodatário no período justinianeu.

206 Cf. Id. Ibid., p. 117-118, e TARDIVO, Carlo-Maria. op. cit., p. 86-88. Segundo LUZZATTO, Giuseppe Ignazio, uma possível incongruência quanto à sistematização dos graus de responsabilidade pelos juristas bizantinos, poderia ser argüida neste texto, já que Inst. 3, 14, 2, fala em “diligentia exacta”, enquanto que Gai. 2 aureor, D. 44, 7, 1, 4, fala de “diligentia exactissima”. Esta diferença terminológica pode ser mais uma vez resolvida pela diferente elaboração da Res Cottidianae por parte dos compiladores das Iustiniani Institutiones e daqueles dos Digesta. Na redação mais antiga de Inst. 3, 14, 2, a responsabilidade contratual não havia ainda encontrado critérios seguros, o que poderia responder a esta diferença. Mas também não se deve esquecer que talvez se tratar de um erro dos amanuenses, uma vez que alguns manuscritos falavam em “exactissimam" e não "exactmam”. Porém, de qualquer modo, faz-se referência a um critério abstrato de responsabilidade baseado na regra da utilitas. 
adhibere solitus est, si modo alius diligentior poterit eam rem custodire: sed propter maiorem vim maioresve casus non tenetur, si modo non huius culpa is casus intervenerit: alioquin si id quod tibi commodatum est peregre ferre tecum malueris et vel incursu hostium praedonumve vel naufragio amiseris, dubium non est, quin de restituenda ea re tenearis. commodata autem res tunc proprie intellegitur, si nulla mercede accepta vel constituta res tibi utenda data est. alioquin mercede interveniente locatus tibi usus rei videtur: gratuitum enim debet esse commodatum.

O comodatário, que recebe uma coisa para dela se servir, fica obrigado pela tradição e responde pela ação de comodato. Ele difere muito do mutuário, pois, quando recebe a coisa, não se torna dono, e deve restituir a mesma coisa que recebeu. [Ao contrário,] O mutuário que perde a coisa por um caso fortuito, como, por exemplo, por incêndio, ruína, naufrágio, ataque de ladrões ou de inimigos, continua, da mesma forma, obrigado. Já o comodatário, ainda que deva responder por exactam diligenitam custodiendae rei (não bastando a mesma diligência que tem com suas coisas, se outra pessoa mais cuidadosa poderia ter evitado a perda), não responde por fortuito ou força maior ocorridos sem sua culpa. Porém, se levares em viagem a coisa que te foi entregue em comodato, e a perderes, seja em um ataque de inimigos ou de ladrões, seja em um naufrágio, ficas obrigado a restituí-la. O comodato existe tecnicamente quando se recebe uma coisa para dela se utilizar sem remuneração alguma; se esta houver, existe locação do uso da coisa, já que o comodato deve ser gratuito.

Ambos estes textos, que se diferenciam pouquíssimo entre si, são extraídos de um mesmo trecho das Res Cottidianae (Libri Aureorum), ${ }^{207}$ como se fossem uma leitura paralela. Tanto nas Institutiones como nos Digesta, o fragmento vem citado em conexão com o tratamento sobre as "Obligationes quae re contrahuntur" (Gai. 3, 90-91).

No início de dos textos faz-se uma alusão a um rol no qual se incluem o comodato, o depósito e o penhor: contratos que não eram considerados reais na época de Gaio, e apenas tutelados sobre o prisma do ius honorarium. Logo, quanto a este tratamento é impossível que os dois textos sejam originais de Gaio. E, ao se considerar

\footnotetext{
207 Segundo ARANGIO-RUIZ, Vincenzo. Responsabilità... cit., p. 63, a última utilização das Gai Institutiones ocorreu nas Iustiniani Institutiones, redigidas sob a presidência de Triboniano, e com a participação de Doroteo e Teófilo. Mas, entre as Instituições clássicas gaianas e imperiais justinianéias, respectivamente, o ponto de partida e o ponto de chegada, a mediação - a travessia, a ligação - é feita pelas Res Cottidianae [= "Assuntos do Dia-a-dia"], ou Libri Aureorum [= "Livros Dourados"], larga parte da qual, especialmente em matéria de obrigações, é reproduzida nos Digesta e nas próprias Iustiniani Institutiones, e que constituiu uma fonte pós-clássica e pré-justinianéia, conduzida sobre o texto das Gai Institutiones.
} 
que Gai. 2 aureor., D. 44, 7, 1, 4, apresenta uma série de interpolações, tanto formais como substanciais, é certo que grande parte deste seja obra ou dos juristas pós-clássicos, dos quais foi fruto a nova elaboração das Res Cottidianae, ou dos compiladores justinianeus. ${ }^{208}$

Desconfia-se que os escritores justinianeus teriam diante dos olhos esta nova elaboração pós-clássica, que teria sido conservada, salva pequenas alterações, tanto nas Iustiniani Institutiones como nos Digesta. Ademais, os juristas pós-clássicos não teriam feito esta nova elaboração do texto das Gai Institutiones, por este ter ficado intacto no manuscrito veronense, mas sim que este teria uma segunda versão, muita próxima da primeira, feita pelo próprio Gaio. ${ }^{209}$

Giuseppe Ignazio Luzzatto ${ }^{210}$ propõe, para esclarecer o texto, dois problemas centrais, visando a determinar o que em Gai. 2 aureor., D. 44, 7, 1, 4, seria clássico, pósclássico e justinianeu.

O primeiro é que se deve considerar que ambos os textos - Inst. 3, 14, 2, e D. 44, 7, 1, 4 - sofreram uma nova elaboração pós-clássica, tanto formal, como substancial, ou seja, mesmo se excluído que os compiladores justinianeuss teriam tido contato com o texto original de Gaio quanto ào tratamento das "Obligationes quae res contrahuntur", é possível perceber nos dois textos o original clássico que os compiladores posteriores mantiveram. ${ }^{211}$

O segundo problema consiste em determinar o contrário até onde for possível, ou seja, o quanto dos textos foi obra pós-clássica e o quanto seria de caráter justinianeu. $^{212}$

O fato é que em ambos os textos, quanto ao conteúdo, são iguais, uma vez que se respeitou a mesma antítese entre mútuo e comodato e com o mesmo relevo da utilitas contrahentium, a partir do que poderia se determinar ser talvez pós-clássico o desenvolvimento desta regra a partir da oposição destes dois contratos. ${ }^{213}$

${ }^{208}$ LUZZATTO, Giuseppe Ignazio. Caso fortuito... cit., p. 117-120, e TARDIVO, Carlo-Maria. op. cit., p. 8688. Tem-se reconhecido nas Res Cottidianae uma nova elaboração pós-clássica, que seria incorporada quase totalmente, salvo qualquer modificação ou inserção realizada pelos compiladores de Justiniano.

209 Cf.Id. Ibid., p. 120-121. Além disso, Giuseppe Ignazio Luzzatto também desconfia que os compiladores das Iustiniani Institutiones teriam tido contato com uma alteração mais difusa, enquanto que os dos Digesta a um epitome, ou sinópse, o que parece ser confirmado em um paralelo realizado entre ambos os textos, onde o texto das Iustiniani Institutiones é notadamente mais longo e mais seguro, no sentido de conter mais expressões de origem gaiana.

210 Id. Ibid., p. 120-121, e TARDIVO, Carlo-Maria. op. cit., p. 86-88.

211 Id. Ibid., p. 121, e TARDIVO, Id. Ibid., p. 86-88. O problema é justamente saber se os compiladores criaram um diverso tratamento, ou mantiveram algum espaço para o modelo original das Gai Institutiones. É o caso de ambos os fragmentos, nas Iustiniani Institutioni e nos Digesta, onde se traçou um paralelo exato entre a responsabilidade no comodato (empréstimo de uso) e no mútuo (empréstimo de consumo).

212 Id. Ibid., p. 121, o qual acredita ser extremamente radical considerar que todas as alterações dos textos sejam de origem tão somente pós-clássica.

213 Id. Ibid., p. 122, e TARDIVO, Carlo-Maria. op. cit., p. 86-88. 
Entretanto, a perfeição destas oposições são traços marcadamente gaianos, o que demonstra uma ausência desta nova elaboração pós-clássica. É, aliás, muito provável que os juristas pós-clássicos tenham, por exemplo, aceito o modelo gaiano de oposição entre o depósito e o comodato, afirmando a responsabilidade por custodia deste e por dolus daquele. ${ }^{214}$

Os juristas pós-clássicos teriam retirado o texto da própria sedes materiae e transportado para o tratamento das "Obligationes quae re contrahuntur". 215

De qualquer modo, a oposição entre comodato e mútuo parece seguramente clássica. $^{216}$

Mais delicado é separar o segundo problema, isto é, sabendo-se qual seria a parte clássica dos textos, determinar qual ou quais seriam as modificações pós-clássicas e quando se teriam as interpolações realizadas por obra dos compiladores de Justiniano, ou, pelo menos, determinar a qual época pertence as modificações pós-clássicas e qual seria o estágio de evolução destas no contexto da responsabilidade contratual. ${ }^{217}$

Entretanto, no estado em que os dois textos se apresentam nos dias atuais - o das Iustiniani Institutiones e dos Digesta - demonstra que, por traz destes, operou-se

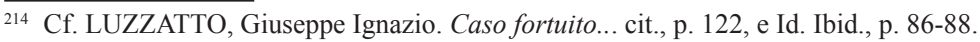

215 Id. Ibid. Teriam os compiladores justinianeus, quando receberam o texto gaiano que traçava as diferenças entre o comodato e o depósito, em nome da definição e da sistematização, atribuído diferentes pressupostos à responsabilidade, tanto que inseriam o comodato no conjunto de contratos reais. E, assim, teriam, segundo Giuseppe Ignazio Luzzatto, que igualmente difundir a responsabilidade subjetiva com seus devidos limites, e, logo, os excertos em que a custodia aparece substituída pelas diversas figuras da diligentia, como também o trecho que trata do casus maior, não poderia ser clássica.

ARANGIO-RUIZ, Vincenzo. Responsabilità... cit., p. 72-73, considera que, pela menção a este conjunto de contratos reais, Gai. 2 aureor., D. 44, 7, 1, 4, não poderia ser um texto propriamente de Gaio. Este fez parte do tratamento das "Obligationes quae re contrahuntur", ou seja, dos contratos reais, que deveria corresponder a uma outra de mesmo argumento, contida em Gai. 3, 90-91. Mas em Gai. 3, 90-91, o tratamento somente se desenvolve ao redor do mútuo e do pagamento indevido, enquanto em Gai. 2 aureor, D. 44, 7, 1, pretensamente retirado das Res Cotidianae, trata das categorias do mútuo, do comodato, do depósito e do penhor. Estes três últimos contratos foram excluídos do tratamento conferido pelas Gai Institutiones, uma vez que a obligatio romana, bem como o contractus, eram compreendidos como uma categoria própria do ius civile, o qual, por sua vez, excluía estes três últimos, por serem criações pretorianas. Por isso, pode-se sustentar que não somente a parte que se refere à responsabilidade contratual no parágrafo em análise, mas inclusive todo o bloco de Gai. 2 aureor., D. 44, 7, 1, teria sido inserido por compiladores pós-clássicos da Res Cotidianae. Estes juristas pós-clássicos poderiam ou ter inventado completamente o texto, ou se valeram de materiais oferecidos pelas Gai Institutiones. Mas o relevo que o texto confere à responsabilidade do comodatário e do depositário faz pensar que estes juristas teriam sido atraídos pelas palavras de Gai. 3, 204207, e, não podendo os escrever como eram, refrasearam-os para o seu tempo. De qualquer forma, não restam dúvidam de que os juristas que realizaram a paráfrase tinham sobre os olhos a expressão de Gaio "custodiam praestare", como se pode constatar na confrontação da frase "exactissimam diligentiam custodiendae rei praestare compellitur" com "necesse habet custodiam praestare", de Gai. 3, 206.

${ }_{216}$ Deve-se lembra-se do tratamento adotado por Gai. 3, 206-207.

217 Cf. LUZZATTO, Giuseppe Ignazio. Caso fortuito... cit., p. 123. 
uma ampla evolução, que poderia levar uma alteração substancial até mesmo no período justinianeu. ${ }^{218}$

Giuseppe Ignazio Luzzatto socorre-se do desenvolvimento que a "teoria da culpa-casus" fornece. ${ }^{219}$

Constata-se facilmente que em PS. 2, 4, 3, e Modest., Coll. 10, 2, 1 e 4, somente se menciona a palavra culpa sem distinguir qualquer grau desta, isto é, concebida como mera atitude subjetiva que corresponde, no outro lado, ao casus, na época também sem distinção de graus. ${ }^{220}$

Desta evolução resulta, com quase certeza, que a gradação da responsabilidade subjetiva, segundo um modelo abstratamente pré-determinado, e que encontra expressão nos diversos graus de diligentia da compilação justinianéia, era estranha às fontes pósclássicas do séculos IV e V, que somente conheciam a passagem de uma responsabilidade objetiva para a subjetiva de forma genérica e abstrata. ${ }^{221}$

Além disso, levando-se em conta que estes dois textos de Gaio, presentes no Corpus Iuris Civilis, foram objeto de uma "doppia stratificazione" [= "dupla estratificação"], pós-clássica e justinianéia, e que a culpa pós-clássica seria transformada nos diversos graus da diligentia justinianéia, parece que se tem um resultado, ao menos, altamente provável. Assim, a diligentia, segundo a regra da utilitas, somente é desenvolvida em época justinianéia, ou, com maior precisão, pouquíssimo tempo antes da compilação de Justiniano. $^{222}$

Se esta linha de raciocínio e de desenvolvimento da própria responsabilidade civil romana for verdadeira, a tentativa de separar o que seria pós-clássico do que seria justinianeu seria encontrado no próprio conteúdo dos textos em exame.

Nestes fragmentos não se encontra uma culpa pura e simples, mas sim uma graduação da responsabilidade pseudo-subjetiva, que se apóia na teoria da utilitas e se afasta somente pela força maior, que é o limite a diligentia exactissima: os textos

218 LUZZATTO, Giuseppe Ignazio. Caso fortuito... cit., p. 124.

219 Cf. Id. Ibid., p. 124-125.

220 Id. ibid., p. 125.

221 Cf. Id. Ibid., p. 125. E, assim, a compilação romano-germânica, enquanto referente ao textos do C. Th. 2, 31, 1 , e das PS. 2, 4, 3, e à contraposição culpa-casus, não vai além disto, sendo que a diligentia, em todas as suas graduações, seria estranha ao desenvolvimento ocidental, e não poderia ser extraída do período pós-clássico romano.

222 Cf. Id. Ibid., p. 126. Também KUNKEL, Wolfgang. op. cit., p. 271, acredita na origem genérica da diligentia, ou seja, sem graduações. O testemunho de que a diligentia aparece em um contexto pós-clássico já estaria em PS. 2, 4, 3: "Servus vel equus in aliam causam commodati si a latronibus vel in bello occisi sunt, actio commodati datur; custodia enim et diligentia rei commodatae praestanda est" [= "O escravo ou o cavalo mortos por ladrões ou na guerra, se por qualquer outra causa foram entregues em comodato, dá-se lugar à actio commodati (directa): na realidade (o comodatário) há de responder tanto por custódia como por diligência."]. Texto em latim de BAVIERA, Johannes. FIRA II. 
em questão pressupõem, por esta linha de raciocínio, que todo o iter da responsabilidade subjetiva foi realizado, e que já nos encontraríamos diante da famigerada graduação da diligentia. ${ }^{223}$

E, assim, ao se voltar a análise para o texto de Gaio contido nas Res Cottidianae, inserido em Gai. 2 aureor., D. 44, 7, 1, 4, e Inst. 3, 14, 2, percebe-se que, além do fato deste último ser mais extenso em quase todas as partes, a graduação da diligentia e a contraposição entre casus maior e casus minor são menos difundidas - e, provavelmente, seguras - no segundo que no primeiro.

Desta forma, o texto Inst. 3, 14, 2, ainda respeita a evolução para a graduação da diligentia e do casus, e, pelo contrário, o texto de Gai. 2 aureor., D. 44, 7, 1,4 , representa a sistematização decisiva e final dos compiladores justinianeus, no tempo em que este foi finalizado. ${ }^{224}$

E uma livre e nova elaboração, ou resumo, teria ocorrido em época diversa, ou seja, enquanto o texto das Iustiniani Institutiones teria sofrido uma nova elaboração um pouco anterior, os compiladores dos Digesta teriam diante de si a cópia resumida, que representaria uma mais precisa sistematização da responsabilidade contratual e da teoria do caso fortuito, tendo em mente os últimos estágios da evolução da responsabilidade subjetiva dos juristas orientais. ${ }^{225}$

Portanto, segundo Giuseppe Ignazio Luzzatto, ${ }^{226}$ poderia-se supor em Gai. 2 aureor., D. 44, 7, 1, 4, e em Inst. 3, 14, 2, uma tríplice estratificação.

A mais antiga seria um exemplar clássico, que teria sido alterado pelo próprio Gaio, e no qual existia uma correspondência entre a responsabilidade por custodia e a casuística concreta por determinados eventos.

Uma elaboração pós-clássica menos recente, mas mesmo assim bastante próxima da compilação final de Justiniano, cujos indícios são claros em Inst. 3, 14, 2, uma vez que nesta está presente uma responsabilidade subjetiva baseada na culpa, da qual, ainda com incertezas, podem-se vislumbrar diversos graus, o que corresponde à teoria do casus [= "acaso"], que já tenderia a graduar, mas sem o ter ainda feito.

E a terceira estratificação, já próxima ou contemporânea a compilação justinianéia, fortemente presente em Gai. 2 aureor., D. 44, 7, 1, 4, onde a diligentia já

${ }^{223}$ Cf. LUZZATTO, Giuseppe Ignazio. Caso fortuito... cit., p. 126. Desta forma, supõe-se que alteração pósclássica tenha ocorrido em época extremamente próxima da compilação justinianéia.

${ }^{224}$ Cf. Id. Ibid., p. 127. Confirma-se, assim, a opinião de ARANGIO-RUIZ, Vincenzo. Responsabilità... cit., p. 62-82, segundo a qual a nova elaboração das Res Cottidianae teria ocorrido em época tardia, muito próxima da compilação justinianéia.

225 Id. Ibid., p. 128.

226 Id. Ibid., p. 128. Para Giuseppe Ignazio Luzzatto o relevo destes textos, assumindo esta hipótese de trabalho como verdadeira, ou, ao menos, altamente provável, está em demonstrar as fases da evolução da própria responsabilidade contratual com base em uma valorização subjetiva e em uma teoria do caso fortuito. 
aparece nitidamente graduada conforme o esquema abstrato da regra da utilitas, e já se distingue entre casus maior [= "força maior"] e casus minor [= "caso fortuito"], sendo este imputado implicitamente ao comodatário. ${ }^{227}$

Giuseppe Ignazio Luzzatto ${ }^{228}$ acredita que, embora a distinção entre caso fortuito e força maior, conduza, pela exactissima diligentia custodiendae rei, à imputação ao comodatário de determinados eventos, isto não significaria um retorno à responsabilidade por custodia do devedor, mas apenas uma "sofisticação" da responsabilidade subjetiva através do critério da utilitas. ${ }^{229}$

Vincenzo Arangio-Ruiz ${ }^{230}$ também entende que na frase "exactissima diligentia custodiendae rei" o conceito clássico de custodia aparece absorvido e transformado de critério objetivo para critério subjetivo de responsabilidade, além de ser uma frase gramaticalmente incorreta, pois deveria ter sido escrito "diligentia in custodienda re" ao invés de "diligentia custodiendae rei", não podendo, assim, ter sido escrita por um clássico: o que seria confirmado por um outro texto de Gaio.

Em Gai. 9 ad ed. provinc., D. 13, 6, 18 pr., o tema da responsabilidade do comodatário seria mais uma vez retomado, mas mesmo este teria sido amplamente

${ }^{227}$ Assim, segundo LUZZATTO, Giuseppe Ignazio. Caso fortuito... cit., p. 128-129, as modificações - e a evolução - destes dois textos é extremamente tardia e muito próxima da compilação justinianéia. Segundo G. I. Luzzatto somente quando é levada ao extremo a graduação da diligentia, com a criação da diligentia exactissima que se imputa ao comodatário, que aparece em ambos os textos a oposição entre um "casus minor cui resisti no potest" e um implícito casus minor. Nas demais partes, em que se fundamenta uma responsabilidade diversa, a palavra "casus" aparece pura e simplesmente, sem se ter uma expressão a esta equivalente. Deste modo, se, por um lado, a criação da teoria do caso fortuito seria pós-clássica, esta evolução terminaria com a interpretação dos autores bizantinos que traçam expressamente a distinção entre casus maior e minor. Apenas neste momento da evolução da responsabilidade se imputaria ao comodatário a diligentia exactissima - uma típica figura de responsabilidade justinianéia - com base na distinção entre casus minor e maior, correspondentes, respectivamente, às diligências ordinária e extraordinária.

HAYMANN, Franz. op. cit., p. 202-203, acredita que existem, no mínimo, quatro interpolações, em Gai. 2 aureor., D. 44, 7, 1, 4: "maiore", "cui humana infirmitas resistere non potest", "Alias tamen exactissimam diligentiam custodiendae rei praestare compellitur nec sufficit ei eadem diligentiam adhibere quam suis rebus adhibet, si alius diligentior custodire poterit", e "et in maioribus casibus". Ademais, em sua opinião, a frase "Alias tamen [...] custodire poterit" não quer significar a intensificação da responsabilidade culposa pelo casus minor, mas sim a falta - "Alias" - de um "anerkannten Exkulpationsgrunds" [= reconhecido motivo de não-responsabilização]. Este motivo de não-responsabilização seria a possibilidade do comodatário de demonstrar o efetivo emprego da diligentia exactissima em uma espécie de política de compensação de danos. Em outros termos, a imputação de determinados eventos fortuitos ao comodatário somente seguiria uma linha de política legislativa, mas sem que se estruturasse como responsabilidade objetiva, embora lembrasse a custodia. Também quanto à "caça às interpolações", cf. PFLÜGER, Heinrich Hackfeld. op. cit., p. $132,(=\S 1)$

${ }^{228}$ LUZZATTO, Giuseppe Ignazio. Caso fortuito... cit., p. 129.

229 No mesmo sentido, KUNKEL, Wolfgang. op. cit., p. 271-274, afirma que ao se utilizar a palavra custodia, em "exactissima diligentia custodiendoe rei", tratar-se-ia, na realidade, de uma utilização bastante superficial, pois, pelo seu conteúdo, conclui-se que se trataria de uma figura total e absolutamente não-clássica. Em Gai. 2 aureor., D. 44, 7, 1, 4, narrar-se-ia uma longa repartição de riscos baseados na diligentia.

230 ARANGIO-RUIZ, Vincenzo. Responsabilità... cit., p. 73. 
retocado, e não se sabe se por juristas pós-clássicos ou justinianeus. Neste, com maior chance, a custodia estaria no texto original e foi substituída por "talis diligentia", que, conjuntamente com "diligentissimus pater familias", constituem interpolações. ${ }^{231}$

Gai. 9 ad ed. provinc., D. 13, 6, 18 pr.:"In rebus commodatis talis diligentia praestanda est, qualem quisque diligentissimus pater familias suis rebus adhibet, ita ut tantum eos casus non praestet, quibus resisti non possit, veluti mortes servorum quae sine dolo et culpa eius accidunt, latronum hostiumve incursus, piratarum insidias, naufragium, incendium, fugas servorum qui custodiri non solent. quod autem de latronibus et piratis et naufragio diximus, ita scilicet accipiemus, si in hoc commodata sit alicui res, ut eam rem peregre secum ferat: alioquin si cui ideo argentum commodaverim, quod is amicos ad cenam invitaturum se diceret, et id peregre secum portaverit, sine ulla dubitatione etiam piratarum et latronum et naufragii casum praestare debet. haec ita, si dumtaxat accipientis gratia commodata sit res, at si utriusque, veluti si communem amicum ad cenam invitaverimus tuque eius rei curam suscepisses et ego tibi argentum commodaverim, scriptum quidem apud quosdam invenio, quasi dolum tantum praestare debeas: sed videndum est, ne et culpa praestanda sit, ut ita culpae fiat aestimatio, sicut in rebus pignori datis et dotalibus aestimari solet.

Sobre as coisas entregues em comodato, deve-se prestar igual diligência àquela que um diligentissimus pater familias dispensa a suas coisas, de forma que não somente se responde por aqueles acidentes que não se podem resistir, como, por exemplo, a morte dos escravos, que sobrevêm sem seu dolo ou culpa, os rompantes dos ladrões e dos inimigos, os saques dos piratas, um naufrágio, um incêndio e a fuga dos escravos, que não podem ser custodiados. Mas o que temos dito a respeito dos ladrões, dos piratas, e do naufrágio, o entendemos desta forma, se a coisa tivesse sido dada para que alguém a levasse consigo em viagem. Por outro lado, se eu tivesse dado em comodato um jogo de prata, porque ele [o comodatário] me disse que iria convidar alguns amigos para a ceia, mas leva o jogo para uma viagem, sem dúvida que [o comodatário] deve responder pelos ladrões, pelos piratas e pelo naufrágio. Em outras palavras, a coisa somente foi dada em comodato por causa daquele que a recebe, como, por exemplo, se tivéssemos convidado um amigo em comum para jantar, e você se encarregou disso, e eu te dei em comodato um jogo de prata, certamente você somente responderá pelo dolo; porém também deverá se analisar se

$\overline{231}$ ARANGIO-RUIZ, Vincenzo. Responsabilità... cit., p. 73. 
não deve responder pela culpa, de modo que exista uma estimação da culpa, assim como se faz com as coisas dadas em penhor, ou em dote.

O texto traz as mesmas idéias que Gai. 2 aureor., D. 44, 7, 1, 4, no qual se examina a responsabilidade do comodatário: ${ }^{232}$ Gai. 9 ad ed. provinc., D. 13, 6, 18 pr., ${ }^{233}$ e Gai. 2 aureor., D. 44, 7, 1, 4, exigem, respectivamente, do comodatário uma "diligentia diligentissimi patrisfamilias" ou uma "diligentia exacta (exactissima)". ${ }^{234}$

Estas expressões, Segundo Julius Baron, ${ }^{235}$ representam a possibilidade de compreender a custodia em sentido técnico. Os juristas romanos teriam entendido que esta diligência especial nada mais seria do que uma norma objetiva, cuja observância excede a pessoa do próprio indivíduo e compreende a responsabilidade tanto por conduta alheia, como por casus minor. Em outros termos, seria a custodia técnica.

Contardo Ferrini ${ }^{236}$ acredita ser descabida a pretensão, defendida por J. Baron, de que as expressões seriam corolário de uma responsabilidade objetiva: em Gai. 9 ad ed. provinc., D. 13, 6, 18 pr., por exemplo, este critério de responsabilidade é utilizado para distinguir a diligência exigida do comodatário em um caso normal, onde o negócio gera benefício apenas para uma das partes, da diligentia quam suis, quando o negócio origina proveito para ambas as partes..$^{237}$

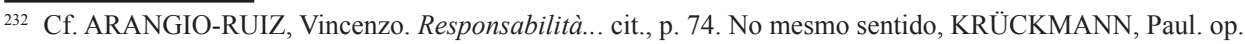
cit., p. 32.

${ }^{233}$ Cf. POLÁCEK, Vojtech. op. cit., p. 175 e 183, segundo o qual em Gai. 9 ad ed. provinc., D. 13, 6, 18 pr., apresenta-se o mesmo pensamento de Gai. 2 aureor., D. 44, 7, 1, 4, mas a segunda parte daquele apresenta um aspecto novo, ou seja, a diferença em se fazer um banquete feito pelo devedor apenas para seus amigos e uma festa comum para a qual seria convidado até mesmo o amigo financiador. Em ambos os casos, a discussão que se cria é sobre a responsabilidade do comodatário. E uma atenta leitura demonstra que Gaio não tem em mente um comodato de dinheiro ad pompam vel ostentationem, mas sim o dinheiro entregue in commodatum como meio material por meio do qual o banquete seria realizado. Em outras palavras, o comodatário não recebeu o objeto somente para o expor aos olhos do convidados (recebe, enfim, o dinheiro em comodato para comprar uma jogo de prata que será usado no banquete). E se distinguem duas hipóteses. Na primeira o comodatário iria dar um banquete em sua casa e na segunda pela qual o comodatário deveria ser convidado como amigo comum. Neste último caso, o comodatário responde somente por dolus, o que Gaio não concorda.

${ }^{234}$ FERRINI, Contardo. op. cit., p. 153. Sobre a correlação destas expressões, cf. também KRÜCKMANN, Paul. op. cit., p. 33.

${ }^{235}$ BARON, Julius. op. cit., p. 427, 429-430, 505-506 (= §§ 237 e 275). Ao contrário de Vincenzo Arangio-Ruiz e de Giuseppe Ignazio Luzzatto, FERRINI, Contardo. op. cit., p. 153-164, acredita que a frase "diligentia diligentissimi patrisfamilias" é propriamente de Gaio (D. 13, 6, 18 pr.), da mesma forma que "diligentia exactissima" também pertence ao mesmo (Gai. 2 aureor, D. 44, 7, 1, 4, e Inst. 3, 14, 2). A frase "diligentia exacta" encontra-se em Inst. 3, 14, 2, extraído das Res Cottidianae, e Julius Baron a considera equivalente à "diligentia exactissima" de Gai. 2 aureor., D. 44, 7, 1, 4 (o original seria "exacta diligentia" que teria sido substituída por outra expressão nos Digesta). KUNKEL, Wolfgang. op. cit., p. 271, julga impossível considerar o texto de Gai. 9 ad ed. provinc., D. 13, 6, 18 pr., como original.

${ }^{236}$ FERRINI, Contardo. op. cit., p. 154.

${ }^{237}$ Cf. Id. Ibid., p. 155. O jurista teria se preocupado em dizer que não bastaria ao comodatário dispensar o mesmo cuidado que tem com as coisas próprias à coisa emprestada, uma vez que precisa existir a premissa 
Vincenzo Arangio-Ruiz ${ }^{238}$ denomina Gai. 3, 205-207, como "genuíno", e Gai. 2 aureor., D. 44, 7, 1, 4, como "falsificado". 239

E aqui se torna útil reforçar o argumento de que enquanto nas Gai Institutiones existe um sistema totalmente coerente, no qual a responsabilidade do furto feito por terceiro é claramente estabelecida, nos textos da compilação justinianéia - Gai. 2 aureor., D. 44, 7, 1, 4- existe uma contradição insanável entre a exactissima diligentia, posta como critério da responsabilidade do comodatário, e o dado de que este somente se liberta da responsabilidade pela vis maior. ${ }^{240}$

Entretanto, Vincenzo Arangio-Ruiz ${ }^{241}$ reconhece, ao contrário de Giuseppe Ignazio Luzzatto, que esta contradição explica-se pela intenção de não se renunciar às conseqüências práticas que os clássicos conferiam à custodia, e ao fato de ter que se recorrer a uma espécie de "presunzione di negligenza" [= "presunção de negligência"] em todos os casos que não fossem de vis maior, o que, por sua vez, poderia denotar exatamente que o conceito de responsabilidade objetiva repugnava a mentalidade bizantina.

A responsabilidade por custodia realmente vem transfigurada no critério subjetivo da exactissima diligentia custodiendae rei, mas acaba por ser "cosi un regime

para que com as coisas próprias se tenha o cuidado de um diligentíssimo paterfamilias. O terreno seria indubitavelmente da culpa e da diligentia, sendo que o superlativo, não para se referir a uma responsabilidade objetiva - a custodia no sentido técnico - mas para contrastar a presença de uma maior diligência. O mesmo raciocínio encontrar-se-ia em Gai. 2 aureor, D. 44, 7, 1, 4, e em Inst. 3, 14, 2. Porém, o grande empecilho do raciocínio desenvolvido por Julius Baron, encontra-se, segundo Contardo Ferrini, em Gai. 5 ad ed. provinc., D. 4, 9, 5 pr. Aqui o tintureiro e o alfaiate podem estar obrigados, por convenção ex locato, não somente pela falta ou defeituosa execução de seu trabalho, mas até mesmo por consequências derivadas do perecimento da coisa entregue. Para distinguir os sentidos da palavra custodia nas fontes romanas, deve-se atentar para as locuções utilizadas pelos juristas. Neste texto, Gaio escreve duas vezes “custodiae nomine teneri". Esta expressão não se encontra em nenhum outro fragmento de Gaio, nem nos demais escritores, e indica uma obrigação pela qual alguém é responsável pela diligência empregada com a coisa, ou mesmo nos casos que Julius Baron denomina de responsabilidade objetiva. A frase que costuma apresentar esta utilidade é “custodiam praestare”. Logo, Gaio somente pode ter se referido com a frase "custodiae nomine teneri" à diligente custodia.

Deve-se notar que falar em uma diligente custodia pode soar, por si, uma contradição. Une-se um critério característico da responsabilidade subjetivo, com outro que, dentre seus sentidos, denota a responsabilidade objetiva no Direito Romano.

238 ARANGIO-RUIZ, Vincenzo. Responsabilità... cit., p. 73.

239 Uma teoria que começou a ser desenvolvida por HEUMANN, Hermann Gottlieb; SECKEL, Emil. op. cit., p. 116-117. Já KUNKEL, Wolfgang. op. cit., p. 271, considera tanto Gai. 2 aureor., D. 44, 7, 1, 4, como Gai. 9 ad ed. provinc., D. 13, 6, 18 pr., como falsificados, pois o Gaio "original" das Institutiones apenas fala da "custodia-Haftung des Entleihers" [= "responsabilidade por custódia do comodatário"].

240 Cf. ARANGIO-RUIZ, Vincenzo. Responsabilità... cit., p. 78.

241 Id. Ibid., p. 79-80. Ainda existe um outro confronto a ser feito entre o texto indubitavelmente clássico de Gai. 3, 206, e o texto certamente bizantino de Gai. 2 aureor, D. 44, 7, 1, 4. No primeiro, não se usa a expressão a "casus maior", mas, no segundo, o comodatário somente encontra sua responsabilidade afastada quando se tem "casus maior cui resisti no potest”, e, em seguida, o conceito é retomado, para advertir que mesmo "in maioribus casibus” a responsabilidade existirá, se existir uma violação prévia do contrato. 
che praticamente no diversifica gran fatto dal 'praestare custodiam' di Gaio" [= "um regime, assim, que praticamente não é tão diverso do custodiam praestare de Gaio"]. ${ }^{242}$

Em sentido semelhante, Gaetano Scherillo ${ }^{243}$ sustenta que, nas fontes, em Inst. 3, 14, 2, em Gai. 9 ad ed. provinc., D. 13, 6, 18 pr., e em Gai. 2 aureor., D. 44, 7, 1, 4, que tratam diretamente do caso fortuito e da força maior, o comodatário é obrigado a observar a diligentia, ou melhor a diligentia custodiendae rei. ${ }^{244}$

Deste modo, a conclusão de que o comodatário responderia, no período clássico, por custodia e seria obra dos justinianeus a introdução da responsabilidade por culpa ou pela diligentia parece soar agora um tanto equivocada e precipitada. ${ }^{245}$

Em primeiro lugar, pois os juristas, no período justinianeu, não eliminaram de todos os textos a menção da custodia, substituindo-a pela culpa, ou pela diligentia, mas apenas proclamaram a responsabilidade pela culpa em textos gerais e, às vezes, inseriram estes dois critérios de responsabilidade ao lado da custodia. É o caso de Ulp. 28 ad ed., D. $13,6,5,6$ e 14 .

O pior é que a mudança não é tão brusca como parece: a exacta diligentia custodiendae rei, em Inst. 3, 14, 2, em Gai. 9 ad ed. provinc., D. 13, 6, 18 pr. e em Gai. 2 aureor., D. 44, 7, 1, 4, que apresenta como limite apenas a vis maior, não seria nada se não a custodia com um outro nome, apregoada em uma idéia subjetiva, que a vê como exacta diligentia custodiendae rei..$^{246}$

Wolfgang Kunkel ${ }^{247}$ teve a perspicácia de sintetizar todas estas tendências, ou seja, se a exactissima diligentia custodiendae rei de Gai. 2 aureor., D. 44, 7, 1, 4, seria

${ }^{242}$ Cf. ARANGIO-RUIZ, Vincenzo. Responsabilità... cit., p. 74, 78 e 80. Ele lembra que ao contrário do Direito Civil moderno, onde a responsabilidade objetiva se aplica às grandes necessidades do comércio, no Direito Romano a custodia se relacionava com as mais simples atividades do dia-a-dia, entre as quais, o comodato.

243 SCHERILLO, Gaetano. op. cit., p. 988.

244 Id. Ibid., lembra que in sede materiae, Ulp. 28 ad ed., D. 13, 6, 5, 3-4, afirma que o comodatário responde pela diligência com limite à força maior, e em Ulp. 28 ad ed., D. 13, 6, 5, 5, seria obrigado a uma custodia diligente.

245 Id. Ibid., p. 988.

246 Id. Ibid., p. 989.

${ }^{247}$ KUNKEL, Wolfgang. op. cit. (nota 15 supra), p. 286. Entretanto, fugiu-se de uma defesa em um ou outro sentido. Wolfgang Kunkel acaba por querer circundar a questão no "uso indevido" ou no "abuso" proposital dos limites estabelecidos do objeto emprestado, o que não oferece uma resposta clara para a exactissima diligentia custodiendae rei. No mesmo sentido, CICOGNA, Giovanni. op. cit., p. 235-236, 245-247. Giovanni Cicogna acredita que se, por um lado, não há como negar que a visão predominante é que o objeto entregue em comodato deva servir a um escopo estritamente particular e rigorosamente determinado, por outro lado, a coisa entregue em comodato pode também ser utilizada em um uso mais ou menos amplo - que não deixa de ser determinado e preciso, uma vez que é previsto expressamente no contrato -, ou mesmo para um uso que resulta das circunstâncias da própria coisa e do caso concreto - o qual igualmente não deixa de ser preciso, pois da mesma forma pondera-se sobre a destinação para a qual a coisa foi entregue. Porém, a partir do momento em que se pode determinar o uso pelas circunstâncias que se apresentam, abre-se um caminho para que o comodato possa ser concluído sem mesmo uma declaração específica do uso. Neste caso, o comodatário deveria se utilizar da coisa conforme os ditames da boa-fé, sempre considerando a existência da presunção de um uso permitido 
uma forma de responsabilidade subjetiva, derivada da culpa, ou se somente foi fruto da sistematização justinianéia das regras clássicas, e sendo, neste último caso, reflexo da responsabilidade objetiva, que sorveu a custodia clássica.

Entretanto, também já se defendeu uma terceira posição sobre a exactissima diligentia custodiendae rei: Paul Krückmann ${ }^{248}$ acredita que as palavras custodia e diligentia não são utilizadas em sentido diverso, uma vez que não existe custodia sem diligentia e tanto uma como a outra mantém alguma relação com a "Zuffalshaftung" [= "responsabilidade pelo caso fortuito"], pois ambas se afastam com a ocorrência da vis maior.

Trata-se de um raciocínio perigoso, que para Hermann Gottlieb Heumann e Emil Seckel ${ }^{249}$ deve ser evitado, pois mesmo se culpa, ou diligentia, possam, no período justinianeu, significar custodia, as duas primeiras podem ter graduações, enquanto o mesmo não pode ocorrer com a esta, sendo este um sinal distintivo de interpolação.

Embora atualmente tenha se defendido que a exactissima diligentia custodiendae rei seja apenas uma responsabilidade subjetiva, ${ }^{250}$ deve-se notar que grande parte da doutrina, mesmo os que sustentam esta possibilidade, é unânime em afirmar que este critério de responsabilidade não se afasta muito da custodia, ${ }^{251}$ justamente por se fundamentar em um sistema de presunções. ${ }^{252}$

\section{2. Considerações finais e sobre o Direito Civil Moderno}

Resta notar, brevemente, que o mesmo argumento do Direito Romano, também foi desenvolvido no Direito Civil moderno, especialmente por Agostinho Alvim. ${ }^{253}$

A idéia da responsabilidade objetiva é "primitiva", pois se foca no nexo causal, e se exclui a necessidade da prova da culpa: e, por este motivo, deve ficar adstrita aos seus "justos limites".

pelo comodante. Parece que esta visão de Giovanni Cicogna soa desarrazoada, uma vez que o uso sempre é "determinado", seja expressamente, seja pela natureza da coisa ou pelas circunstâncias negociais.

248 KRÜCKMANN, Paul. op. cit., p. 33.

${ }^{249}$ HEUMANN, Hermann Gottlieb; SECKEL, Emil. op. cit., p. 112-113, 116-117.

${ }^{250} \mathrm{O}$ estudo mais atual sobre o tema sustenta ainda esta posição. Cf. MERCADO, Javier Belda. op. cit., p. 5. No mesmo sentido, KASER, Max. Das Römische Privatrecht II... cit., p. 254 (= § 258).

${ }^{251}$ SCHERILLO, Gaetano. op. cit., p. 989; ARANGIO-RUIZ, Vincenzo. Responsabilità... cit., p. 74, 78 e 80; e inclusive PASTORI, Franco. Il contratto... cit., p. 94.

${ }^{252}$ Cf. ARANGIO-RUIZ, Vincenzo. Responsabilità... cit., p. 74, 78 e 80.

${ }^{253}$ AGOSTINHO, Alvim. Da inexecução das obrigações e suas coneqüências. 5. ed. São Paulo: Saraiva, 1980. p. 244-245, 275-276 (= ns. 171 e 183). Ele entende que ainda vale a concepção de que a responsabilidade subjetiva é a regra, e a objetiva a exceção. 
Mas os "sistemas de presunções da culpa" trazem um efeito inesperado (ou, a priori, não esperados) para o campo da responsabilidade civil. ${ }^{254}$

Ao se presumir que o devedor agiu culposamente porque teve uma má vigilância ou uma péssima escolha, acaba-se por se igualar a teoria da presunção da culpa à teoria do risco. Entretanto, trata-se de uma equiparação que somente ocorre quando se tem uma praesumptio iuris et de iure, justamente quando não se pode ter a prova em sentido contrário.

A contrario sensu, se esta presunção for relativa, não se conduz à responsabilidade objetiva, mas permanece-se no campo da doutrina subjetiva, ou seja, se for presunção absoluta aplicar-se-ia a teoria do risco (objetiva), mas se for relativa, aplicase a doutrina da culpa. ${ }^{255}$

Entretanto, é justa a observação que a presunção de culpa não é teoricamente sinônimo de responsabilidade objetiva: mas, acaba por provocar um efeito, na prática, semelhante.

Em complemento a isto, o Direito Civil moderno acabou por fixar a responsabilidade do comodatário na "culpa levis in abstracto valorizada", 256 algo semelhante ao critério justinianeu da exactissima diligentia custodiendae rei.

Pela "culpa levis in absctracto", o comodatário deve ter a diligência de um bom pai de família, mas, segundo Franco Carresi, sem que se altere este parâmetro, a diligência do comodatário deve ser "valorizada", ou seja, o juiz deve tratar sua responsabilidade com menor ou maior "rigor", para determinar a imputação do evento ao comodatário.

Hermann Gottlieb Heumann e Emil Seckel ${ }^{257}$ ainda acreditam que a palavra culpa pode significar um critério de responsabilidade subjetiva, mas, em outros casos, ela somente retoma o conteúdo da custodia clássica, isto é, nesta última hipótese, mudou-se o nome, mas não o conteúdo da responsabilidade.

\footnotetext{
254 AGOSTINHO, Alvim. op. cit., p. 275 (= n. 183). A culpa presumida foi o caminho encontrado, atualmente, para que se atingisse a teoria do risco. No início, começou-se a tomar o fato como culpa, a fim de que o devedor fosse responsável mesmo naqueles casos em que a prova de sua responsabilidade fosse dificílima. Tratava-se de um artifício para encobrir o abandono da culpa como fundamento de responsabilidade. Percebendo que o fato carecia dos elementos da culpa, ou pelo menos de um deles (a imputabilidade), abriu-se mão da culpa como fundamento da responsabilidade, deixando para trás o disfarce da presunção da culpa em todo fato gerador de dano, e se abrindo caminho para o vocábulo mais adequado, vale dizer, "prescindiu-se", não só "presumiu-se", da culpa. Trata-se do famoso "trompe l'oeil" ou "conto do vigário". Entretanto, a rigor não se deve falar de culpa, nem de presunção de culpa no campo da responsabilidade objetiva.

255 Id. Ibid., p. 276 (= n. 183). Parece que mesmo na presunção relativa, quando a prova da não-culpa for praticamente impossível, praticamente volta-se a se tangenciar a responsabilidade objetiva.

256 CARRESI, Franco. op. cit., p. 59-61. AGUIAR DIAS, José. op. cit., p. 26, prevê a culpa levissima. Esta, que imputa ao devedor pela menor falta possível, tangencia novamente a responsabilidade objetiva. O estranho é que José de Aguiar Dias é o maior representante da responsabilidade objetiva no Brasil.

257 HEUMANN, Hermann Gottlieb; SECKEL, Emil. op. cit., p. 112-113, 116-117.
} 
Tratar-se-ia justamente da exactissima diligentia custodiendae rei de Gai. 2 aureor., D. 44, 7, 1, 4, ${ }^{258}$ bem como de Gai. 9 ad ed. provinc., D. 13, 6, 18 pr., e Inst. 3, 14,2 .

Heinrich Hackfeld Pflüger ${ }^{259}$ afirma que este critério justinianeu de responsabilidade do comodatário corresponde a uma idéia de "schuldigen custodia" [= “custódia culpável"], expressão cunhada pelo autor que, embora possa parecer logicamente absurda em um primeiro momento, consegue se referir a uma conceito objetivo de responsabilidade com um adjetivo referente à responsabilidade subjetiva. Uma idéia utilizada para articular a responsabilidade por custodia com as tendências pós-clássicas e justinianéias de responsabilidade. ${ }^{260}$

Portanto, conclui-se que se a exactissima diligentia custodiendae rei constitui, na teoria, uma realização de um plano legislativo justinianeu em prol da responsabilidade subjetiva graduada - correspondente à terceira estratificação do texto -, mas, na prática, devido a um sistema intrincado de presunções, a responsabilidade do comodatário continuou a ser a custodia clássica, podendo-se afirmar que este critério tipicamente justinianeu de responsabilidade só tem a diligentia como nome.

Além disso, embora se deseje sustentar que esta seja uma compensação de danos, ${ }^{261}$ ao se utilizar a expressão "maiore casu", que somente pode significar "força maior", implícita fica a diferença entre caso fortuito e força maior. Gai. 2 aureor., D. 44, 7, 1, 4, a contrario sensu, imputa ao comodatário o caso fortuito que nada mais seria que a custodia. ${ }^{262}$

${ }^{258}$ HAYMANN, Franz. op. cit., p. 202-204, expressamente afirma que, se, por um lado, não restam dúvidas de que a expressão diligentia custodiendae rei é uma interpolação, por outro lado, admite que a figura lembra a custodia clássica, mas com a possibilidade do devedor alegar que empregou toda a diligência para evitar a ocorrência do evento. Enfim, uma custodia só de nome, pois completamente reformulada dentro dos parâmetros da responsabilidade subjetiva.

259 PFLÜGER, Heinrich Hackfeld. op. cit., p. 133 (= § 1).

${ }^{260}$ Id. Ibid., p. 132-133 (= § 1). A custodia, segundo Heinrich Hackfeld Pflüger, é o “Fleiß”, um "modo de ser do amor", que recai sobre o comodatário para que este evite que a coisa emprestada sofra qualquer dano ou avaria. Por isso, não se fala em "diligentia rei", mas sim em "diligentia custodiendae rei". A única diferença entre os períodos clássico, pós-clássico e justinianeu a este respeito seria o modo como a responsabilidade por custodia é expressa. Os clássicos obrigam ao comodatário "custodiam praestare" (Gai. 3, 206), enquanto os pós-clássicos e justinianeus falam em "custodiam praestare" ou "diligentem" (Ulp. 28 ad ed., D. 13, 6, $5,3)$. De qualquer forma, seria símbolo do amor ao superlativo.

${ }^{261}$ HAYMANN, Franz. op. cit., p. 202-203.

262 A terceira parte do texto ("sed et in maioribus casibus - amiserit") não seria nada mais que uma regra de responsabilidade subjetiva, uma vez que sempre que a "culpa [...] interveniat", o comodatário irá responder. A palavra culpa aqui deve ser entendida lato sensu, ou seja, englobando a culpa, em sentido estrito, e o dolus. Referindo-se à responsabilidade do comodatário por culpa, constrói-se uma regra geral sobre esta. Porém, o conector "sed" [= "mas"] do início desta parte, demonstra uma nítida oposição com as duas anteriores ("Et ille quidem - securus est" e "alias tamen - custodire poterit"): enquanto as duas primeiras, partindo de uma distinção clássica entre o mútuo e o comodato, referem-se à responsabilidade, na prática, objetiva, pela qual o comodatário responde apenas na ocorrência de caso fortuito, esta terceira parte afirma a responsabilidade 


\section{Conclusão}

A partir da proposta de análise da responsabilidade do comodatário nos períodos da História Interna do Direito Romano, com devida atenção ao período justinianeu, e da exegese de Gai. 2 aureor., D. 44, 7, 1, 4, pode-se passar agora a enunciar algumas conclusões.

A primeira destas é que a responsabilidade do comodatário nunca foi, pelo menos desde o fim do período clássico, "simples", ou seja, baseada em apenas um critério de responsabilidade. Mas, pelo contrário, foi e ainda é "multifacetada", fundando-se em mais de um critério autônomo de responsabilidade, característica esta que se acentua - e não diminuii ${ }^{263}$ - com a evolução do Direito Romano.

Desde Gai. 4, 47 e 62, assim como, a partir do testemunho de Paul. 29 ad ed., 13, 6, 17, 3, reconheceu-se uma duplicidade formular aplicável à actio commodati directa, ou seja, uma actio in factum que tutelaria a responsabildiade por custodia e uma mais tardia, embora ainda clássica, "actio in ius" que concretizaria a responsabilidade baseada na culpa ou diligentia. ${ }^{264}$

No período clássico, o comodatário, por decorrência expressa de Gai. 3, 206, respondia, ao lado de outros devedores, como o fullo e o sarcinator, por custodia em sentido técnico, ou seja, respondia objetivamente por meio da formula in factum concepta. Por outro lado, parece correto o entendimento de Vincenzo Arangio-Ruiz, ${ }^{265}$ segundo o qual, já nesta época, o comodatário responderia por dolus.

Além disso, acredita-se que já tardiamente no período clássico, por introdução da formula in ius, já se teria demandado do comodatário o critério subjetivo da culpa. ${ }^{266}$

Entretanto, a plenitude da convivência do critério da culpa ou lado da custodia, até por estruturação plena da duplicidade formular, ocorreria apenas no período pós-clássico: é o testemunho certo de PS. 2, 4, 3, e de Modest., Coll. 10, 2, 1 e 4, sendo

subjetiva do comodatário, que responde sempre por sua culpa e dolus. Enfim, o raciocínio desenvolvido pela exactissima diligentia custodiendae rei não se altera por força exclusiva desta terceira parte do texto.

${ }^{263}$ Como julgariam os defensores, principalmente LUZZATTO, Giuseppe Ignazio. Caso fortuito... cit., p. 117131, 145-146, e ARANGIO-RUIZ, Vincenzo. Responsabilità... cit., p. 62-99, que a custodia teria sido extinta no período justinianeu por força do critério subjetivo da culpa.

${ }^{264}$ Trata-se de consenso doutrinário esta correlação entre os critérios de responsabilidade e as fórmulas do pretor, devido à própria estrutura destas, cf. PASTORI, Franco. Il commodato... cit., p. 1-3. O que LUZZATTO, Giuseppe Ignazio. Commodati... cit., p. 359-361, discute é a possibilidade de se imputar um critério objetivo pela actio in ius, uma vez que esta teria se alargado no período justinianeu em razão da prevalência do critério da culpa, mas nunca defendeu, a contrario sensu, a imputação de um critério subjetivo pela actio in factum.

265 ARANGIO-RUIZ, Vincenzo. Istituzioni... cit., p. 381-382. Baseia-se na máxima de que "todas as partes respondem por dolo".

${ }^{266}$ Cf. item 3. 1, supra. 
que, no primeiro, a custodia é expressa em um sentido técnico ao lado da culpa, e, no segundo, a custodia é subentendida em seu caráter atécnico. ${ }^{267}$

$\mathrm{O}$ que realmente interessa saber, para os objetivos aqui almejados, é se, no período justinianeu, o "fenômeno de enfraquecimento" descrito por Max Kaser"268 teria extinto a custodia, com prevalência plena da culpa, ou se, pelo contrário, a custodia tenha, por determinados motivos, continuada a ser imputada ao comodatário.

A exegese de Gai. 2 aureor., D. 44, 7, 1, 4, constata que o comodatário responde pelo típico critério justinianeu da exactissima diligentia custodiendae rei: ${ }^{269}$ mas que, embora legislativamente represente uma orientação em direção à responsabilidade subjetiva, na prática, devido a um sistema de presunções da culpa, ${ }^{270}$ ocorreriam os mesmos efeitos da custodia clássica. ${ }^{271}$

Na mesma direção, o direito moderno ${ }^{272}$ imputa ao comodatário a "culpa levis in abstracto valorizada", algo em muito semelhante ao critério justinianeu da exactissima diligentia custodiendae rei: a diligência do comodatário deve ser "valorizada", ou seja, o juiz deve tratar sua responsabilidade com menor ou maior rigor, para determinar a imputação do evento ao comodatário.

Mas por qual motivo teria a custodia sobrevivido na responsabilidade do comodatário no período justinianeu?

${ }^{267}$ Assim, no período pós-clássico, o comodatário responderia por dolus, culpa, ainda sem graduações, segundo LUZZATTO, Giuseppe Ignazio. Caso fortuito... cit., p. 145-146, e custodia.

AGOSTINHO, Alvim. op. cit., p. 243 (= n. 170), narra o que ele denomina de "movimento de vaivém da responsabilidade civil", ou seja, a responsabilidade no Direito Romano teria sido, ao menos no início, objetiva; passaria a ser, em seguida, subjetiva; e, no século XX, voltaria a ser objetiva. A tese deste autor, conforme demonstrado, demonstra-se, ao menos quanto a este argumento ultrapassada, uma vez que não descreve a plena coexistência dos critérios de responsabilidade, mas apenas a substituição de um por outro. Desta forma, o "vaivém" não deve ser entendido apenas sob o ponto de vista externo, quando um critério substitui o outro por inteiro, mas também do ponto de vista interno do negócio jurídico, inaugurando-se a possibilidade de critérios diversos de responsabilidade tutelarem o mesmo negócio em um único período histórico.

${ }^{268}$ KASER, Max. Das römische Privatrecht II... cit., p. 271 (= § 262).

${ }^{269}$ Embora as diferenças gramaticais, o critério reaparece em Gai. 9 ad ed. provinc. D 13, 6 , 18 pr., e Inst. 3, 14, 2. Até o "tipicamente justinianeu" deve ser questionado, pois, se, por um lado, trata-se de uma construção justinianéia, por outro lado, seu conteúdo é clássico.

270 Presunção absoluta, que não admite prova em contrário, e presunção relativa, onda a prova da culpa demonstra-se, muitas vezes, impossível.

${ }^{271}$ Cf., entre outros, ARANGIO-RUIZ, Vincenzo. Responsabilità... cit., p. 79-80; HEUMANN, Hermann Gottlieb; SECKEL, Emil. op. cit., p. 112-113, 116-117; PASTORI, Franco. Il commodato... cit., p. 261-273; e SCHERILLO, Gaetano. op. cit., p. 989.

${ }^{272}$ AGOSTINHO, Alvim. op. cit., p. 244-245, 275-276 (= ns. 171 e 183), e CARRESI, Franco. Il comodato... cit., p. 59-61. 
Embora exista um medo por sua subsunção categórica, por outro lado, como demonstra Otto Lenel, ${ }^{273}$ os juristas estavam acostumados com sua aplicação, o que demonstra um cepticismo de se julgar através de critérios abertos como a boa-fé e a culpa.

$\mathrm{E}$, de fato, a custodia apresenta, como vantagem frente à culpa, a capacidade de determinar com limites exatos a responsabilidade do comodatário. ${ }^{274}$

A custodia representava a tradição, enquanto a culpa a inovação: acostumados com um critério preciso, os juristas tiveram que trabalhar com um outro absolutamente diverso, o que pode ter levado a sua transfiguração, em termos práticos, ao primeiro.

Assim, a defesa tradicional sobre o comodato, ${ }^{275}$ segundo a qual o comodatário respondia por custodia, no direito clássico, e por culpa, no período justinianeu, não é tão exata quanto aparenta.

A partir do indício certo fornecido pelas fontes, a custodia estava presente na responsabilidade do comodatário no período justinianeu, ou seja, neste o comodatário respondia por dolus malus, culpa, e custodia.

Portanto, o comodatário respondia desde o fim do direito clássico até a atualidade de forma "multifacetada": dependendo da fattispecie em que se encontra sua responsabilidade pode ser subjetiva, ou objetiva.

E, assim, a custodia romana ecoou na eternidade.

São Paulo, novembro de 2009.

Referências

ALVES, José Carlos Moreira. Direito Romano. História do Direito Romano. Instituições de Direito Romano: parte geral. Parte Especial: direito das coisas. 13. ed. Rio de Janeiro: Forense, 2004.

ALVES, José Carlos Moreira. Direito Romano. Instituições de Direito Romano. Parte especial: direito das obrigações; direito de família; direito das sucessões. 6. ed. Rio de Janeiro: Forense, 2005. v. 2.

ALVIM, Agostinho. Da inexecução das obrigações e suas conseqüências. 5. ed. São Paulo: Saraiva, 1980.

ARANGIO-RUIZ, Vincenzo. Istituzioni di diritto romano. 14. ed. Napoli: Jovene, 2006.

LENEL, Otto. op. cit., p. $253(=\S 98)$.

${ }^{274}$ HAYMANN, Franz. op. cit., p. 168-169. TALAMANCA, Mario. op. cit., p. 562, especula que o âmbito de cabimento da custodia teria aumentado pelo choque com o critério subjetivo da culpa. Isto pode sinalizar um receio de trabalhar com um critério indeterminado e aberto como a culpa, o que pode também assinalar que as presunções, cujos os efeitos se aproximam da responsabilidade objetiva, talvez sejam seus frutos, ou seja, herdeiras da determinação precisa da custodia, embora com todas as divergências teóricas.

275 Em especial, PASTORI, Franco. Il commodato... cit., p. XV-476; LUZZATTO, Giuseppe Ignazio. Caso fortuito... cit., p. 117-131; ARANGIO-RUIZ, Vincenzo. Responsabilità... cit., p. 62-99. 
ARANGIO-RUIZ, Vincenzo. Responsabilità contrattuale in diritto romano. 2. ed. Napoli: Jovene, 1987.

BARON, Julius. Pandekten. 9. ed. Leipzig: Duncker \& Humblot, 1896.

BAUDRY-LACANTINERIE, Marie Paul Gabriel; WAHL, Albert. Traité théorique et pratique de droit civil. De la société, du prêt, du depôt. 2. ed. Paris: Des lois et des arrêts, 1900.

BIONDI, Biondo. Istituzioni di diritto romano. Milano: Giuffrè, 1946.

BORSARI, Luigi. Commentario del codice civile italiano. Torino: UTET, 1881. v. 4, t. 2.

BRUNORI, Ernesto. Dei contratti specialli. Comodato. In: FINZE, Enrico; D’Amelio, Mariano (Orgs.). Commentario al codice civile. Firenze: Barbèra, 1949. v. 2, p. 1-507.

BUSSI, Emilio. La formazione dei dogmi di diritto privato nel diritto comune. Contratti, successioni, diritti di famiglia. In: STUDI di diritto privato italiano e straniero diretti da Mario Rotondi. Padova: CEDAM, 1971. v. 27.

CARRESI, Franco. Comodato (diritto civile). In: AZARA, Antonio (Org.). Novissimo Digesto Italiano. Torino: UTET, 1959. v. 3, p. 692-696.

CARRESI, Franco. Il comodato. Il mutuo. In: VASSALI, Filippo (Org.). Trattato di Diritto Civile Italiano. Torino: UTET, 1950. v. 8, t. 2, p. 5-136.

CICOGNA, Giovanni. Ancora sull'uso nel comodato. In: Bullettino dell'Istituto di Diritto Romano. Roma: Giuffrè, 1907. v. 19. p. 235-254.

DE RUGGIERO, Roberto; MAROI, Fulvio. Istituzione di diritto privato. Diritto di obbligazione e contratti. Tutela dei diritti. 6. ed. Messina: Giuseppe Principato, 1947. v. 2, p. 1-732.

DIAS, José de Aguiar. Comodato. In: SANTOS, J. M. Carvalho. Repertório Enciclopédico do Direito Brasileiro. Rio de Janeiro: Borsoi, 1947. v. 10, p. 24-26.

ENNECCERUS, Ludwig; KIPP, Theodor; LEHMANN, Heinrich; WOLFF, Martin. Lehrbuch des Bürgerlichen Rechts - Recht der Schulverhältnisse. Tübingen: Mohr, 1954, v. 2, p. 569-1051.

FERRINI, Contardo. Storia e teoria del contratto di commodato nel diritto romano. In: OPERE di Contardo Ferrini. Studi vari di diritto romano e moderno. Sulle obbligazioni, sul negozio giuridico, sulle presunzioni. Milano: Ulrico Hoepli, 1929, v. 3, p. 81-203

FERRINI, Contardo. Storia e teoria del contratto di comodato nel diritto romano. In: ARCHIVIO Giuridico "Filippo Serafini”, 1893. v. 52, p. 469-499; 1894, v. 53, p. 41-73, p. 257-309.

FORCHIELLI, Paolo. I contratti reali. Milano: Giuffrè, 1952.

FRAGALI, Michele. Del comodato. In: SCIALOJA, Antonio; BRANCA, Giuseppe(Orgs.). Commentario del Codice Civile. Delle obligazioni. Bologna: Nicola Zanichelli, 1953. v. 4, t. 1 p. I-571. 
FRANÇA, Rubens Limongi. Contrato de empréstimo. In: ENCICLOPÉDIA Saraiva do Direito. São Paulo: Saraiva, 1977. v. 19, p. 320-324.

HASSE, Joham Christian. Die «Culpa » des römischen Rechts. 2. ed. Bonn: Adolph Marcus, 1838.

HAYMANN, Franz. Textkritische Studien zum römischen Obligationenrecht - I - Über Haftung für Custodia. Zeitschrift der Savigny-Stiftung für Rechtsgeschichte - Romanistische Abteilung, Weimar, v. 40, p. 167-350, 1919.

HEUMANN, Hermann Gottlieb; SECKEL, Emil. Handlexicon zu den Quellen des römischen Rechts (1846). 9. ed. Jena: Gustav Fischer, 1926.

KASER, Max. Das römische Privatrecht. Die nachclassischen Entwicklungen. München: Beck, 1959, v. 2.

KASER, Max. Römisches Privatrecht. 6. ed. München: Beck, 1968.

KOBER, Karl. Leihe. In: STAUDINGER, Julius Ritter (Org.). Kommentar zum Bürgerlichen Gesetzbuch und dem Einführungsgesetz. Recht der Schuldverhältnisse. 9. ed. München: Schweitzer, 1929 , v. 2, t. 2, p. 636-650.

KRÜCKMANN, Paul. Custodia. Zeitschrift der Savigny-Stiftung für Rechtsgeschichte Romanistische Abteilung, Weimar, v. 64, p. 1-56, 1944.

KUNKEL, Wolfgang. «Diligentia». Zeitschrift der Savigny-Stiftung für Rechtsgeschichte Romanistische Abteilung, Weimar, v. 45, p. 266-351, 1925.

LENEL, Otto. Das Edictum Perpetuum: Ein Versucht zu seiner Wiederherstellung (1883). 3. ed. Leipzig: Tauchnitz, 1883.

LUZZATTO, Giuseppe Ignazio. «Commodati... vel contra». In: LABEO: Rassegna di diritto romano. Napole: Jovene, 1955-. v. 2, p. 357-362.

LUZZATTO, Giuseppe Ignazio. Caso fortuito e forza maggiore come limite alla responsabilità contrattuale. La responsabilità per custodia. Milano: Giuffrè, 1938, v. 1.

LUZZATTO, Giuseppe Ignazio. Custodia (diritto romano). In: AZARA, Antonio. Novissimo Digesto Italiano. Torino: UTET, 1960. v. 5, p. 93-94.

MAIA, Paulo Carneiro. Comodato. In: ENCICLOPÉDIA Saraiva do Direito. São Paulo: Saraiva, 1977. v. 16, p. 272-283.

MARMITT, Arnaldo. Comodato. 3. ed. Rio de Janeiro: AIDE, 2002.

MAYR, Robert. «Praestare ». Zeitschrift der Savigny-Stiftung für Rechtsgeschichte - Romanistische Abteilung, Weimar, v. 42, p. 198-227, 1921.

MERCADO, Javier Belda. La responsabilidad del comodatario en el derecho romano. Revista Electrónica de la Facultad de Derecho de la Universidad de Granada, Granada, p. 1-23, 2007. 
METRO, Antonino. «Custodiam praestare». In: LABEO: Rassegna di diritto romano. Napole: Jovene, 1955-. v. 13, p. 60-67.

MICHEL, Jacques. Gratuité en droit romain. Bruxelles: Université Libre de Bruxelles - Institut de Sociologie, 1962.

PASTORI, Franco. Comodato (diritto romano). In: AZARA, Antonio. Novissimo Digesto Italiano. Torino: UTET, 1960-. v. 3, p. 688-692.

PASTORI, Franco. Gaio e la responsabilità contrattuale. In: LABEO: Rassegna di diritto romano. Napole: Jovene, 1955-. v. 2, p. 291-326.

PASTORI, Franco. Il commodato in diritto romano. 3. ed. Milano: Cisalpino, 1995.

PASTORI, Franco. Il contratto di comodato. Bologna: Cisalpino, 1997.

PASTORI, Franco. Sulla duplicità formulare dell' «actio commodati». In: LABEO: Rassegna di diritto romano. Napole: Jovene, 1955-. v. 2, p. 89-94.

PERRIS, Corrado. Comodato (contratto di). In: D’AMELIO, Mariano. Nuovo Digesto Italiano. Torino: UTET, 1938. v. 16, p. 403-408.

PFLÜGER, Heinrich Hackfeld. Zur Lehre von der Haftung des Schuldners nach römischen Recht. Zeitschrift der Savigny-Stiftung für Rechtsgeschichte - Romanistische Abteilung, Weimar, v. 65, p. 121-218, 1947.

POLÁCEK, Vojtech. Comodato e furto: spunti d'interpretazione dialettica. In: LABEO: Rassegna di diritto romano. Napole: Jovene, 1955-. v. 19, p. 161-184.

POTHIER, Robert-Joseph. Traités du prêt a usage et du precaire. In: . Ouevres de Pothier. 3. ed. Paris: Marchal et Billard, 1890. t. 5, p. 1-38.

SANTARELLI, Umberto. Comodato nel diritto medievale e moderno. In: DIGESTO delle Discipline Privatistiche - Sezione Civile. Torino: UTET, 1995-. v. 3, p. 34-37.

SCHERILLO, Gaetano. Comodato (diritto romano). In: ENCICLOPEDIA del Diritto. Milano: Giuffrè, 1958-. v. 7, p. 981-992.

SEGRÉ, Gino. Sull'età dei giudizii di buona fede di comodato e di pegno. In: STUDI giuridici in onore de Carlo Fadda. Napoli: Luigi Pierro, 1906. v. 6, p. 333-390.

SOLAZZI, Siro. La responsabilità del commodatario nelle Istituzioni di Gaio. IVRA: Rivista Internazionale di Diritto Romano e Antico, Napoli, v. 6, p. 139-145, 1955.

SOLAZZI, Siro. Recensão a PASTORI, Franco. Il commodato nel diritto romano - Con contributi allo studio della responsabilità contrattuale. IVRA: Rivista Internazionale di Diritto Romano e Antico, Napoli, v. 6, p. 258-270, 1955.

SOLAZZI, Siro. Una favola su Gai 3.204. In: LABEO: Rassegna di diritto romano. Napole: Jovene, 1955-. v. 3, p. 89-92. 
TALAMANCA, Mario. Custodia (diritto romano). In: ENCICLOPEDIA del Diritto. Milano: Giuffrè, 1958-. v. 11, p. 561-564.

TARDIVO, Carlo-Maria. Studi sul «commodatum». Archivio Giuridico "Filippo Serafini", Modena, v. 204, p. 5-91, 1983.

TROPLONG, Raymond-Théodore. Le droit civil expliqué - Du prêt. Paris: Charles Hingraus, 1845. t. 14.

WEISS, Egon. Institutionen des römischen Privatrechts. 2. ed. Basel: Recht und Gasellschaft, 1949.

WIEACKER, Franz. Haftungsformen des römischen Gesellschaftsrechts. Zeitschrift der SavignyStiftung für Rechtsgeschichte - Romanistische Abteilung, Weimar, v. 54, p. 35-79, 1934.

ZANNINNI, Pierluigi. Comodato nel diritto romano. In: DIGESTO delle Discipline Privatistiche - Sezione Civile. Torino: UTET, 1995-. v. 3, p. 31-34. 